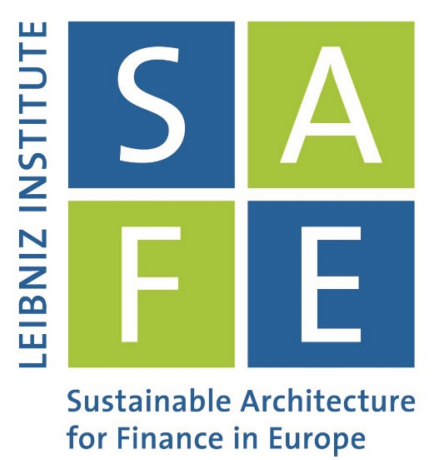

Tobin Hanspal | Annika Weber | Johannes Wohlfart

\title{
Exposure to the COVID-19 Stock Market Crash and its Effect on Household Expectations
}

SAFE Working Paper No. 279

\section{Leibniz Institute for Financial Research SAFE}




\title{
Exposure to the COVID-19 Stock Market Crash and its Effect on Household Expectations*
}

\author{
Tobin Hanspal ${ }^{\dagger} \quad$ Annika Weber ${ }^{\ddagger}$ Johannes Wohlfart ${ }^{\S}$
}

May 21, 2020

First version: April 13, 2020

\begin{abstract}
We survey a representative sample of US households to study how exposure to the COVID-19 stock market crash affects expectations and planned behavior. Wealth shocks are associated with upward adjustments of expectations about retirement age, desired working hours, and household debt, but have only small effects on expected spending. We provide correlational and experimental evidence that beliefs about the duration of the stock market recovery shape households' expectations about their own wealth and their planned investment decisions and labor market activity. Our findings shed light on the implications of household exposure to stock market crashes for expectation formation.
\end{abstract}

JEL Classification: D14, D31, D83, D84, D91

Keywords: Coronavirus, Stockholding, Wealth shocks, Expectation formation, Inequality.

\footnotetext{
*This paper was previously circulated under the title "Income and Wealth Shocks and Expectations During the COVID-19 Pandemic". We are grateful for helpful comments from Carola Binder, Francesco D'Acunto, Michalis Haliassos, Claus Kreiner, Christine Laudenbach, Chris Roth, Sonja Settele, Michael Weber, Rüdiger Weber and seminar participants at Copenhagen and St. Gallen. We thank the Economic Policy Research Network (EPRN) for financial support. The activities of the Center for Economic Behavior and Inequality (CEBI) are funded by the Danish National Research Foundation. We received ethics approval from Goethe University Frankfurt. The survey instructions can be found at the following link: https://sites.google.com/site/tobinhanspal/survey

†Tobin Hanspal, Department of Finance, Accounting and Statistics, WU Vienna University of Economics and Business, e-mail: tobin.hanspal@wu.ac.at

${ }_{\ddagger}^{\ddagger}$ Annika Weber, Department of Finance, Goethe University Frankfurt, e-mail: annika.weber@hof.unifrankfurt.de

$\S$ Johannes Wohlfart, Department of Economics and CEBI, University of Copenhagen, CESifo, Danish Finance Institute, e-mail: johannes.wohlfart@econ.ku.dk
} 


\section{Introduction}

A major part of the wealth of households in the United States and in other industrialized countries is invested in the stock market. While historically investing in the stock market has provided a premium over the long run, it exposes households' savings to volatility and to the risk of market crashes. Most recently, the spread of the COVID-19 coronavirus pandemic and the policy measures put in place to contain the virus have sent major stock markets around the world plummeting, with the S\&P500 losing an unprecedented third of its value during the sharp drop of stock prices in February and March 2020. How do households adjust their plans about spending, investments, and labor supply in response to wealth losses during such a crash? And how do beliefs about the stock market recovery affect individuals' expectations about their own wealth and plans? Answering these questions is crucial for understanding the implications of households' exposure to stock market crashes for the vulnerability of different socioeconomic groups and for the formation of household expectations, which are central to economic models and important determinants of household behavior (Armona et al., 2018; Bachmann et al., 2015; Bailey et al., 2017; Coibion et al., 2019a, 2020b; D’Acunto et al., 2019a; Giglio et al., 2020a; Kuchler and Zafar, 2019).

In this paper we shed light on these issues using a survey on a sample of more than 8,000 US households, representative in terms of age, gender, income, and region, which we conducted in April 2020. We elicit the value of participants' wealth holdings in retirement accounts and in other financial accounts as of January 2020, as well as the capital losses they incurred in those accounts as a result of the drop in stock prices. We then measure respondents' expectations regarding the stock market and their own financial prospects, and elicit their planned decisions with respect to stock investments, spending and labor supply. The survey includes an experimental section, in which random subsets of respondents receive information on the duration of the recovery in the case of a historical stock market crash (the Black Monday crash in 1987, the burst of the Dot-com bubble in 2000, or the 2007-2009 Financial Crisis). These treatments generate 
exogenous variation in our respondents' expectations about the recovery of the stock market from the current crash. Our survey allows us to study how exposed households adjust their plans about investment, spending, debt and labor supply in response to a stock market crash, and how beliefs about the recovery causally shape these plans and people's expectations about their own household wealth. At the same time, our survey offers a comprehensive real-time snapshot of household finances and expectations during the COVID-19 pandemic in the US. ${ }^{1}$

We start by quantifying the exposure of different groups of the population to the February/March 2020 stock market crash. US households report median financial wealth losses of $\$ 1,750$ and mean losses of $\$ 30,415$ at the time of our survey in early April 2020. Relative losses of financial wealth strongly increase in net wealth and income, and are strongest for those in middle age. These differences can largely be explained by differences in the share invested in stocks before the onset of the crisis. Across groups, wealth shocks tend to be negatively correlated with household income shocks experienced during the early stages of the pandemic, which are strongest among the poorest and younger households and almost zero for those with high incomes or wealth and for older households. Wealth shocks due to the stock market crash therefore counteract the role of income shocks in the effect of the pandemic on overall inequality of available economic resources.

How did households adjust their decisions and plans regarding investment, spending, household debt and labor supply in the medium-term in response to the pandemic more generally and to wealth shocks in particular? About 50 percent of households who were invested in the stock market at the onset of the crisis made active adjustments to their stock investments since the beginning of the crash, with about equal shares of respondents increasing and decreasing the stock share in their overall financial wealth. Thus, households did not exhibit a systematic tendency to rebalance their portfolios in response to the decrease in their stock share due to the crash. Moreover, 36 percent of respondents

\footnotetext{
${ }^{1}$ By contrast, data from long-running surveys such as the PSID or from some administrative data sources may only become available with a lag, potentially extended by the shutdown of large parts of the economy, society and public administration.
} 
report that the coronavirus crisis increases their expectations about household debt at the end of 2020 and 44 and 53 percent report that the crisis increases their expectations about their retirement age and desired working hours over the coming years.

Shocks to stock wealth inside and outside of retirement accounts are strongly correlated with upward adjustments in expected desired working hours and retirement age. A ten percent shock to retirement financial wealth is associated with a four percentage points higher tendency to report upward adjustments in retirement age. This suggests that households plan to make up for losses experienced during a crash by increasing labor supply, in line with a key mechanism in portfolio choice models with human capital (Bodie et al., 1992; Gollier, 2002). We find evidence of only small changes in expected household spending in response to wealth shocks, with a $\$ 1$ shock to retirement financial wealth being associated with a $\$ 0.02$ reduction in spending. By contrast, income shocks experienced during the pandemic have strong effects on expected spending, with an average reduction in expected spending in 2020 of $\$ 0.45$ for each $\$ 1$ shock to income. This is consistent with the view that retirement wealth holdings are less liquid and not used to finance current spending. In addition, households hit by wealth shocks tend to be better insured against shocks due to higher savings and easier access to credit.

We next turn to the role of households' beliefs about the further development of the stock market. Respondents who personally experienced losses during past crashes, Democrats, and women expect the stock market to take more time to recover to pre-crisis levels and expect significantly lower returns over the coming year. ${ }^{2}$

Finally, we exploit the information experiment embedded in our survey to examine the causal effects of people's expectations about the stock market recovery on their economic outlook for their own household and their planned economic decisions. When respondents are provided with information on the duration of a longer (shorter) historical stock market crash, this causes them to be more pessimistic (optimistic) about the development of the stock market in the coming years compared to respondents in control groups who have not

\footnotetext{
${ }^{2}$ This is in line with previous literature highlighting the importance of these factors during more tranquil times (D'Acunto et al., 2020; Kuchler and Zafar, 2019; Malmendier and Nagel, 2011).
} 
received information. This suggests that households had not been fully informed about historical facts they consider relevant for the further development of the stock market, pointing to a role for information frictions in households' stock market expectations (Abel et al., 2007; Alvarez et al., 2012). Moreover, respondents update their expectations about their own wealth, their investment plans, and their long-term labor market activity in response to the information. We also find strong correlations between expected recovery duration with these outcomes in OLS regressions. These findings suggest that, next to incurred wealth shocks, expectations about the stock market going forward play an important causal role in shaping households' outlook regarding their own wealth and decisions.

We contribute to a literature studying the formation of households' subjective stock market expectations and their association with economic choices (Ameriks et al., 2019; Amromin and Sharpe, 2014; Das et al., 2017; Dominitz and Manski, 2007; Giglio et al., 2020a; Greenwood and Shleifer, 2014; Malmendier and Nagel, 2011; Vissing-Jorgensen, 2003). Giglio et al. (2020b) document that investor beliefs about the 1-year ahead stock market return declined following the February-March 2020 stock market crash, while expectations over the 10-year horizon remained stable. Guiso et al. (2018) and Weber et al. (2013) study the development of beliefs and risk-taking following the Financial Crisis 2008. We contribute to this literature by providing evidence on how stock market expectations affect individuals' economic outlook and plans in both financial and non-financial domains following a crash. Methodologically, we add to the literature on subjective stock market expectations by applying an information experiment. Such experiments have previously been used to study household expectations about inflation (Armantier et al., 2016; Binder and Rodrigue, 2018; Cavallo et al., 2017; Coibion et al., 2020a, 2019b, 2018), house prices (Armona et al., 2018; Fuster et al., 2019) and GDP growth (Roth and Wohlfart, 2019). To the best of our knowledge, our results provide the first direct causal evidence on the role of subjective return expectations in shaping individuals' planned stock investment behavior in a real-world setting, and the first evidence on the role of financial market expectations in shaping households' long-term plans about labor market activity. 
Our study also adds to previous work studying households' responses to changes in their stock market wealth. Several studies document the finding that households are unlikely to actively rebalance their portfolios to counteract passive changes to their portfolio allocation (Brunnermeier and Nagel, 2008; Calvet et al., 2009). Di Maggio et al. (2019) and Bräuer et al. (2020) estimate small marginal propensities to consume (MPC) out of passive changes in households' stock wealth. ${ }^{3}$ We provide real-time evidence on how stock wealth losses during a crash affect plans about trading, spending, debt as well as long-term labor market activity.

Finally, we contribute to a rapidly expanding literature on the economic and financial consequences of the spread of the coronavirus. Coibion et al. (2020b) study the effect of lockdowns on households' beliefs about inflation, unemployment, and mortgage interest rates, as well as their consumer spending. Binder (2020) examines how beliefs about inflation and unemployment respond to information about the Fed's interest rate response to the coronavirus crisis. Fetzer et al. (2020) study how perceptions of pandemic risk factors shape people's economic sentiment. Gormsen and Koijen (2020) use data on the aggregate equity market and dividend futures to quantify how investors' expectations about economic growth evolve in response to the outbreak of the virus and subsequent policy responses. Relatedly, Dietrich et al. (2020) provide survey evidence on households' perception of the effect of the coronavirus on US GDP growth. Bu et al. (2020) document a sharp decrease in risk-taking stemming from changes in beliefs after the onset of the coronavirus pandemic among survey respondents in China. Others study the impact of the coronavirus shock on labor markets (Adams-Prassl et al., 2020; Bick and Blandin, 2020; Coibion et al., 2020c) and on consumer spending (Andersen et al., 2020; Baker et al., 2020; Cox et al., 2020). We contribute to this literature by providing the first evidence on how financial wealth shocks during the coronavirus crisis affect households' medium-term plans about investment, spending, debt and labor market activity.

The remainder of the paper is structured as follows. In section 2 we describe the

\footnotetext{
${ }^{3} \mathrm{We}$ also relate to a literature making use of survey data on subjective beliefs to study the consumption response to changes in economic resources more generally (Christelis et al., 2019; Fuster et al., 2020; Jappelli and Padula, 2015).
} 
survey and the sample. Section 3 provides descriptive evidence on the distribution of wealth losses across the population. In section 4 we examine how wealth shocks affect households' economic decisions and plans. In section 5 we provide correlational and experimental analysis of the role of people's expectations about the further development of the stock market in their economic plans. Section 6 discusses implications of our findings and concludes.

\section{Survey design and data}

In this section we provide details on the structure and administration of our survey, as well as the characteristics of our sample. ${ }^{4}$

\subsection{Survey design}

Our survey starts with a set of questions on demographics such as age, gender and household income. The respondents then answer questions on the value of i) their retirement accounts and ii) the value of all financial assets they held outside of their retirement accounts at the end of January 2020. We ask them explicitly to think of the value of their assets before the start of the current crisis. To ease cognitive strain we ask our respondents to indicate the brackets into which the values of their assets fell instead of asking them for exact estimates. ${ }^{5}$ Respondents then report the percent shares of financial assets in retirement accounts and of financial assets in other accounts that were invested in stocks or stock mutual funds at the end of January. Finally, they estimate by what percent the value of their retirement accounts and the value of their other financial accounts changed as a result of the stock market developments since the beginning of the crisis until the day of the survey. The survey continues with questions on whether respondents lost their job since the beginning of the year, and whether their net household income in the first quarter of 2020 was higher or lower than they had expected before the crisis,

\footnotetext{
${ }^{4}$ The wording of the survey questions is available at https://sites.google.com/site/tobinhanspal/survey ${ }^{5}$ One concern might be that individuals are imperfectly informed about their retirement wealth. This concern is arguably mitigated by the fact that we conducted our survey at the beginning of April. Pension plan providers usually send out wealth statements to clients on a quarterly basis, so respondents should have received at least one such statement in the weeks prior to the survey. Moreover, plans about spending, investment and labor supply should be affected by perceived shocks to respondents' wealth, which is what we measure in our survey.
} 
and by what percent it was higher or lower.

Respondents then proceed to the short experimental part of the survey. They are randomly allocated into one of seven groups. Respondents in arms FinCrisisInfo and FinCrisisControl are asked to estimate the number of years it took the stock market to recover from the drop during the Financial Crisis in 2007. Only respondents in arm FinCrisisInfo are then provided with the actual number of years it took the stock market to reach its pre-crisis peak (5 1/2 years). Similarly, respondents in arms DotComInfo and DotComControl and in arms BlackMondayInfo and BlackMondayControl report prior estimates and respondents in the respective treatment arm receive information on the recovery duration from the burst of the Dot-com bubble in 2000 (7 years) and the Black Monday stock market crash in 1987 (2 years), respectively. ${ }^{6}$ Although asking respondents to estimate the number of years could have framing effects, such framing effects would likely occur with any method of eliciting these beliefs, and such effects should be common across treatment arms. Finally, respondents in the PureControl arm are not shown any questions on priors or information and immediately proceed to the next part of the survey. Online appendix Table A1 provides an overview of the treatment and control arms.

Next, all respondents report their beliefs about the recovery of the US stock market. They report the calendar year in which they expect the stock market to recover to its January 2020 level, as well as their agreement on three qualitative statements on the severity of the recent drop in stock prices on 7 -point scales. ${ }^{7}$ Respondents are also asked in which year they expect their own household's net wealth to recover to its pre-crisis level, including an option that their net wealth will never recover. Finally, the respondents allocate probabilities across eight intervals into which the US stock market return over the next 12 months might fall, which are mutually exclusive and collectively exhaustive. ${ }^{8}$

\footnotetext{
${ }^{6}$ The information treatments included a dynamic figure contrasting the respondent's prior belief with the information. Online appendix Figure A2 plots an example survey screen for the FinCrisisInfo information treatment.

${ }^{7}$ Specifically, respondents are asked to what extent they agree or disagree with the following statements: "The outbreak of the coronavirus will keep US stock prices below their January 2020 levels for many years."; "The outbreak of the coronavirus has set the level of the stock market back by many years."; "The US stock market will have recovered by the end of the year 2020."

${ }^{8}$ Specifically, respondents report the percent chance they assign to each of the following brackets of aggregate stock returns: less than -30 percent, between -30 and -15 percent, between -15 and -5 percent, between -5 and 0 percent, between 0 and 5 percent, between 5 and 15 percent, between 15 and 30 percent,
} 
The survey continues with a set of questions on respondents' expectations about their own economic and financial situation as well as their decisions. Specifically, respondents answer a qualitative question on the financial prospects of their household, and questions on whether they expect the total spending and the total net income of their household to be higher or lower in 2020 as compared to 2019, and by what percent they expect it to be higher or lower. Those who report an expected reduction in their household income also forecast the year in which they expect their household income to have recovered. The participants then respond to qualitative questions on whether the current crisis affects their expectations about their retirement age, their desired working hours in the next years, as well as their outstanding household debt at the end of 2020. Finally, those who held any equity in the beginning of 2020 are asked whether they have made any active adjustments to the share of their financial assets invested in stocks or stock mutual funds, and whether they plan to do so over the next weeks. The survey ends with additional background questions on topics such as stock investment experience or the value of real estate and debt holdings at the beginning of the year.

Our design with seven survey arms has important advantages. On the one hand, we can study the causal effect of information about past crashes on expectations and plans by comparing individuals who have reported priors and received information about a particular crash with those who only have reported priors (e.g. comparing the FinCrisisInfo and FinCrisisControl arms). On the other hand, we can use the pure control group, who has not received questions or information on past crashes, to provide descriptive evidence that is not affected by drawing people's attention to past crashes. Throughout the analysis, all descriptive figures on survey questions asked after the experimental stage are restricted to the pure control group. All non-experimental regressions using such questions as outcomes restrict the sample to the four control arms to increase power. In the appendix we show versions of these tables using only the pure control group, however. greater than 30 percent. 


\subsection{Data}

Survey administration We collaborated with the survey company Lucid, which is widely used in economic and financial research. The survey was conducted between 6 th and 13 th April 2020. The US stock market had partially recovered at the time of the survey, but still showed drastic losses of close to 20 percent compared to its pre-crisis level, and the number of initial jobless claims had escalated (Figure A1). ${ }^{9}$ Participants were recruited from the provider's online panel and then completed the survey on our own platform. They proceeded to the main survey after initial screening according to demographics in order to achieve representativeness in terms of observables. ${ }^{10}$ In total, 8,156 respondents completed our survey. We drop 162 respondents in the top and bottom percentiles of the response time, as very short or very long response times may indicate inattention to the survey. We also remove 547 respondents who refused to answer any of our questions on financial wealth holdings, as these questions are used extensively throughout the analysis. This leaves us with a sample of 7,447 respondents, who completed the survey within 16.6 minutes on average (13.7 minutes at the median).

Sample characteristics Table 1 shows summary statistics of our sample, including a comparison with targets from the 2018 American Community Survey (ACS). The composition of our sample is close to the general population in terms of gender ( 52 percent females vs 51 percent in the ACS), mean age (48.3 years compared to 47.6 years in the ACS) and median gross household income in the previous year $(\$ 62,500$ vs $\$ 65,700$ in the ACS), as well as Census region of residence. As it is common in online samples, a slightly larger fraction of our respondents have a Bachelor's degree compared to the general population (38 percent in our sample vs 31 percent in the ACS).

Integrity of the randomization Our sample is well-balanced across the seven arms of the experimental part of the survey for a set of key characteristics (see Table A2). To rule

\footnotetext{
${ }^{9}$ An advantage of the survey date is that it should give a more accurate picture of the longer-term wealth shocks due to the crash going beyond the very drastic short-term effects as of mid-March. We cannot meaningfully exploit variation within the one-week survey period, given that different population groups were targeted in the course of the week in order to achieve a representative sample.

${ }^{10}$ Respondents received a small reward for participating in the survey.
} 
out any concerns, we include a set of control variables not only in our non-experimental but also in our experimental estimations.

Variable definitions The survey elicits levels of household income, assets and liabilities by asking respondents to indicate the respective value bin. Shocks to households' financial wealth and net income during the first quarter of 2020 as well as expected differences in household net income and spending in 2020 compared to 2019 are elicited as numerical entries in percentage terms. In order to reduce the impact of outliers in these variables in our analysis, for each variable, we set the top and bottom 2 percent of the distribution to missing. When calculating changes in financial wealth components and income in dollar terms, we first translate percentage changes into dollar terms by multiplying respondents' reported percentage changes and base levels, and then trim the top and bottom 2 percent of the resulting dollar distribution, respectively. ${ }^{11}$ Finally, all dummy outcomes in our regressions are coded as either 0 or 100 in order to bring them on the same scale as independent variables referring to percent changes.

\section{Descriptive evidence: Exposure to the COVID-19 stock market crash}

The main goal of our survey was to examine how exposure to a stock market crash affects households' expectations about investment, spending and labor supply. However, our survey also offers a comprehensive real-time snapshot of the financial situation of households in the US during the early stages of the COVID-19 pandemic. In this section we describe how wealth shocks from the COVID-19 stock market crash are distributed across the population and how they are correlated with income shocks.

Unconditional wealth shocks Panel A of Figure 1 displays the average unconditional percent change (top row) in the value of household financial assets across groups, where those with no financial assets are coded as having experienced a shock of zero. Wealth losses due to the stock market crash are strongly increasing along the net wealth dis-

\footnotetext{
${ }^{11}$ Our results are not sensitive to the exact choice of the cutoff. Results are available upon request.
} 
tribution (left column), with overall financial losses amounting to 4 percent of pre-crisis financial wealth in the lowest quintile and to about 17 percent in the highest quintile. There is a similar gradient of wealth losses along the pre-crisis net income distribution (middle column). The distribution of dollar losses (bottom row) is naturally much more skewed along the net wealth and income distribution, reflecting the strong inequality in financial asset holdings across groups (as shown in Figure A3). Unconditional wealth losses in dollar terms amount to $\$ 30,415$ at the mean and $\$ 1,750$ at the median, and average $\$ 1,311$ in the lowest and $\$ 107,275$ in the highest net wealth quintile.

The right column of Figure 1 displays unconditional capital losses by age group. Percent changes in financial wealth are most pronounced for those aged between 25 and 54 (net capital losses of between 13 and 14 percent), and are markedly lower for younger individuals ( 8 percent) and for older individuals (11 percent for those aged 55-64 and 10 percent for those above 65). Wealth shocks in dollar terms increase in age, reflecting increasing wealth accumulation over people's working life. Across net wealth, income and age groups, both absolute and percent losses are larger for holdings in retirement accounts (e.g., 401Ks or IRAs) than for holdings outside of retirement accounts, largely reflecting higher wealth (see Figure A3) and higher stock shares (see Figure A4) inside retirement accounts.

Figure A5 shows that unconditional wealth shocks are strongly increasing in educational attainment, are stronger for men, and less pronounced for those retired or part-time employed compared to those full-time employed as of January 2020. Given that we ask about household wealth, one should interpret these patterns according to individual-level characteristics with caution.

Conditional wealth shocks The patterns in the distribution of unconditional losses in financial wealth reflect differences across groups in i) the fractions of households with no financial wealth before the crisis, who did not incur any losses, ii) the stock share in financial assets, which differs substantially across groups (see Figure A4), iii) the types of risky assets households invest in, or iv) the tendency to realize losses across groups. While our survey data are not granular enough to address iii), we explore i) and ii) in 
more detail by studying conditional wealth losses across groups. In subsection 4.1 we also address iv) by studying active adjustments to stockholdings across groups.

Figure A6 reproduces Figure 1 for the sample of households who report positive holdings of financial assets inside or outside of retirement accounts as of January $2020 .{ }^{12}$ As before, percent financial losses are increasing in net wealth and income, and are humpshaped in age. However, the patterns are substantially less pronounced than before. Due to differences in the value of financial assets, patterns of dollar changes in wealth across net wealth and income groups remain largely unchanged. Figure A7 restricts the sample further to households investing in stocks or stock mutual funds as of January 2020, which makes the patterns in percent losses across income and wealth groups almost uniform, while the age pattern remains. The last column of Figure A7 highlights that wealth losses are strongly increasing in the pre-crisis portfolio equity share. Finally, Figure A8 plots losses by equity share bin separately for different groups. Mean losses conditional on portfolio equity share are almost equal across groups. This highlights that conditional on holding positive financial wealth, differences in capital losses largely seem to be due to differences in portfolio shares invested in stocks and stock mutual funds. This becomes particularly evident when we compare mean experienced losses between the highest (5) and lowest (1) quintiles. As shown in Table A3, the difference in unconditional wealth losses between the most and least wealthy households of 13 percentage points shrinks to 7 percentage points if we condition on holding positive financial wealth, and declines further to 1.4 percentage points among those with positive investment in equities.

Income shocks How does the distribution of wealth shocks across groups compare with the distribution of income shocks during the early stages of the pandemic? Figure 1 Panel B displays average shocks to household net income in the first quarter of 2020 across groups. We calculate these shocks based on a survey question asking respondents by what percent their household income in the first quarter was higher or lower than they had expected before the crisis. Strikingly, income shocks exhibit the opposite pattern

\footnotetext{
${ }^{12}$ The values in the figure are conditional on positive overall financial wealth holdings and thereby hold the sample fixed across the three bars. The patterns look similar if we condition on positive retirement and non-retirement financial wealth holdings separately.
} 
compared to wealth shocks, with income losses being strongest for households in the bottom net wealth or income quintiles (7 and 6 percent respectively), and gradually becoming less severe, with those in the highest quintiles losing almost no income (top row). There is also a strong age gradient in income losses, with younger households being affected most severely and older households being more insulated. We convert these shocks into dollar changes using the approximation that, before the onset of the crisis, households had expected a quarter of their 2019 income for the first quarter of 2020 (bottom row). Unconditionally, respondents report to have lost $\$ 844$ of net household income over the first quarter 2020, on average. Income losses average $\$ 536$ in the lowest and $\$ 1,047$ in the highest net income quintile. While the income and wealth gradients naturally reverse, the age pattern remains fairly similar as for relative income losses.

Figure A9 provides evidence on the distribution of job losses, the main drivers of shocks to household incomes, among the respondents in our sample. A striking $26 \%$ of our respondents report that they have lost their job from January 2020 until the time of our survey in early April, in line with other recent evidence (Adams-Prassl et al., 2020; Bick and Blandin, 2020; Coibion et al., 2020c). Job losses broadly follow the same patterns as income losses. They are more prevalent for lower net wealth, for lower income and for younger households. Women, individuals with lower education, and part-time workers are also more likely to have lost their jobs.

Taken together, these findings imply that income losses and wealth losses during the early stages of the COVID-19 pandemic tend to be negatively correlated across groups. More generally, households' exposure to stock market crashes is concentrated among groups of households who tend to be less affected by income shocks during recessions (Hoynes et al., 2012). This is in line with earlier findings documenting that wealth inequality tends to decline during recessions, at least in the short run (Kuhn et al., 2019). ${ }^{13}$

\footnotetext{
${ }^{13}$ Given the concentration of stock ownership in households at the top of the distribution, decreasing stock prices tend to reduce wealth inequality across households. However, differences in the relative speed of recovery of equity and housing markets led to a spike in wealth inequality in the aftermath to the 2007-2009 Financial Crisis (Kuhn et al., 2019).
} 
Result 1. Shocks to financial wealth due to the COVID-19 stock market crash are strongly increasing in net wealth and income, and strongest for those in middle age. These patterns are largely due to differences in the fraction of households with no financial assets and in the stock share in financial assets across groups. Wealth shocks tend to be negatively correlated with income shocks during the early stage of the pandemic across groups.

\section{Main results: Effects of the COVID-19 stock market crash on behavior, expectations and plans}

In the previous section we have explored how different groups of households were affected by the February/March 2020 stock market crash. We now turn to our main findings on how households adjust their plans about investment, spending, debt and labor supply in response to the pandemic in general, and to wealth shocks in particular.

\subsection{Changes in risk-taking across groups}

Which groups make adjustments to the share of financial assets invested in stocks or stock mutual funds in response to the crash? Our survey asks all respondents who report positive stockholdings as of January 2020 whether they have actively increased or decreased their overall portfolio share invested in equities (combining retirement and other accounts) since the onset of the crisis, and whether they plan to make active adjustments in the weeks following the survey. The wording of these questions is such that respondents should abstract from passive changes to the equity share due to changes in market prices.

Figure 2 plots the fractions of stockholders who have made active adjustments to their portfolio equity share as a result of the coronavirus crisis across demographic groups (top row). Approximately 50 percent of pre-crisis stockholders have made no active adjustments to the share of their wealth invested in stocks since the onset of the crisis, in line with earlier evidence showing that many households do not rebalance passive changes in their asset allocation (Brunnermeier and Nagel, 2008; Calvet et al., 2009). The remaining stockholders were slightly more likely to actively increase (27.9 percent) than to decrease (22.8 percent) their portfolio share in equities. Households from lower 
wealth and income quintiles and those in older age groups are less likely to have made active changes to their portfolio. Interestingly, while the tendency to realize sales was rather uniform across groups, households higher up in the income distribution and those in younger age cohorts were more likely to actively increase their exposure to the stock market. The bottom row of Figure 2 shows that planned active changes in risk-taking over the next few weeks exhibit very similar patterns as realized adjustments in risk-taking.

What drives households' tendency to make adjustments to the share of their portfolio held in equities in the context of a stock market crash? In Table 2 we regress dummy variables indicating realized or planned active changes in risk-taking on a set of covariates. ${ }^{14}$ Stronger negative income shocks are associated with a stronger tendency to reduce stock investments, potentially due to liquidity needs. By contrast, larger financial losses are associated with a greater likelihood to plan to increase the portfolio equity share, consistent with portfolio rebalancing (Calvet et al., 2009) or a tendency to make up for paper losses due to loss aversion (Imas, 2016). ${ }^{15}$ Respondents who held a higher share of their wealth inside retirement accounts as of January 2020 are less likely to adjust their risk-taking, in line with stronger inertia in retirement accounts (Agnew et al., 2003; Ameriks and Zeldes, 2004; Bilias et al., 2010; Madrian and Shea, 2001). Having made losses in the stock market during the Financial Crisis 2007-9 is associated with a substantially higher tendency to plan and realize sales during the February/March 2020 crash, and a lower tendency to plan and realize purchases. The patterns are less pronounced for

\footnotetext{
${ }^{14}$ Our baseline set of controls includes the respondent's gender, age category, dummies for being married, separated or divorced, or widowed (single being the omitted category), dummies for highest educational attainment of highschool, some college or associate degree, or college degree or higher (below highschool being omitted), dummies for being self-employed, retired, unemployed or other labor market status (in paid employment omitted), a dummy or being the main earner in the household, a z-scored measure of the extent to which the respondent is involved in financial decision-making in the household, dummies for Republicans and for other party affiliation (Democrat being omitted), the logs of net household income, of financial wealth inside and outside of retirement accounts, of all real estate wealth, and of total household debt, a z-scored measure of perceived borrowing constraints, the share of financial wealth invested in stocks and stock mutual funds, a dummy for stock market participation, stock investment experience in years, as well as dummies for Census region and date of the survey. Table 2 uses only respondents in the four control groups, who have not received any information. Table A4 replicates the table using only respondents in the pure control group, who have not received any questions or information on past crashes.

${ }^{15}$ We cannot study the relationship between financial shocks and realized adjustments to risk-taking due to a potential reverse causality problem. Specifically, earlier or later realization of losses directly affects the capital losses households incurred during the pandemic.
} 
experiences during the earlier stock market crashes following the burst of the Dot-com bubble in 2000 or the Black Monday in 1987. These findings are in line with recency bias documented by the literature on the role of experiences in financial risk-taking (Andersen et al., 2019; Laudenbach et al., 2020; Malmendier and Nagel, 2011), and suggest that losing wealth during a stock market crash may have the negative long-run consequence of a greater tendency to sell stocks following market downturns. Finally, men are more likely to make adjustments to their portfolios, but there are no patterns according to education or political affiliation.

Overall, we find that investors were equally likely to reduce or increase their exposure to the stock market, although there is significant variation across groups. This is in line with Giglio et al. (2020b), who document that while respondents on average downward revised their short-run expectations about stock returns and GDP growth during the crash, they remained optimistic about the long-run outlook, and that disagreement across investors increased over the crash. In section 5 we explore our respondents' expectations about the future performance of the stock market and their role in driving plans about investments and other economic decisions.

Result 2. About half of investors make active adjustments to their risky portfolio share during the COVID-19 crisis, with about equal fractions increasing or decreasing their risky share.

\subsection{Effects of shocks on plans about spending, debt and labor supply}

How do US households' adjust their expectations about spending, debt, and labor market activity in response to wealth shocks during the pandemic, and how does the role of wealth shocks compare to that of income shocks?

\subsubsection{Expected spending growth}

The top row of Figure 3 plots households' expected nominal spending growth for the entire year 2020 compared to their spending in 2019 across groups. All groups on average report negative expected spending growth for 2020. Expected cuts to spending are most pronounced in the lowest net wealth quintile and in the middle of the income 
distribution, at about -7 percent. Individuals in age groups between 45 and 54, and between 55 and 64 report the strongest expected reduction in spending of about -10 and -8 percent, respectively. A large part of the average drop in spending is plausibly due to the shutdown of wide parts of society and the economy and the associated reduced consumption possibilities (Coibion et al., 2020b; Cox et al., 2020).

What are the roles of financial wealth and income shocks in households' expectations about their spending? Table 3 column 1 regresses expected percent spending growth on percent shocks to retirement and non-retirement financial wealth and percent shocks to household income in the first quarter of 2020, as well as the baseline set of controls. ${ }^{16}$ While income shocks are strongly associated with an expected spending reduction, there is no significant relationship between wealth shocks and expected changes in spending. To facilitate the interpretation of magnitudes, columns 2 and 3 translate all variables into dollar changes. Column 2 uses the realized shock to household income during the first quarter, while column 3 uses the dollar shock to expected annual household income for 2020 using a 2SLS procedure in order to bring outcome and independent variable to the same scale. ${ }^{17}$ While we find a significant but small expected MPC of 2 cents for a one dollar shock to financial assets in retirement accounts, the MPC out of unexpected income shocks is much larger at 45 cents for each dollar shock to annual income. Shocks to financial wealth outside retirement accounts have no significant effect on expected changes in spending. Figure A10 uses binned scatter plots based on the specification in column 2 to illustrate the strong relationship between income shocks and expected spending growth and the small effect of wealth shocks.

\footnotetext{
${ }^{16}$ Table 3 uses only respondents in the four control groups, who have not received any information. Table A5 replicates the table using only respondents in the pure control group, who have not received any questions or information on past crashes.

${ }^{17}$ The dollar changes in financial wealth are calculated from survey questions on levels and percent changes. The quarterly income change in column 2 is calculated from the survey question on the unexpected percent shock to household income in the first quarter and total 2019 household income, assuming that the respondent had expected its household to earn a quarter of its total 2019 income in the first quarter of 2020. For the annual dollar shock to income in column 3 we use the first quarter dollar income shock to instrument the total expected dollar change in 2020 household income compared to 2019, which is calculated from survey questions on the expected percent change and the level in 2019. The expected dollar change in annual household spending is calculated from questions on expected percent change in spending from 2019 to 2020 and CEX estimates on the levels of annual spending of different groups to proxy spending in 2019.
} 
In Figure A11 we examine heterogeneity in the effect of shocks to expected annual income on expected spending. Income shocks have the most pronounced effect for households with below median age, with below median incomes, or with no liquid assets, and for credit-constrained households, in line with the idea that these groups are more likely to exhibit hand-to-mouth behavior. Moreover, income shocks have particularly strong effects on expected spending of individuals who expect their incomes never to recover, in line with predictions from standard life-cycle models on the differential effects of permanent and transitory income shocks. Figure A12 plots effects of shocks to retirement financial wealth or other financial wealth on expected spending across groups. We find small effects of shocks to retirement wealth among older or retired households, with a $\$ 1$ shock to retirement wealth being associated with a $\$ 0.04$ reduction in expected spending among retired individuals, likely as these households consume or plan to consume from retirement assets. Overall, the small size of the effects of wealth shocks is in line with previous literature documenting small MPCs out of changes in stock wealth (Bräuer et al., 2020; Di Maggio et al., 2019). These findings are consistent with the view that for many households retirement wealth is less liquid and therefore less likely to be used to finance spending. In addition, shocks to financial wealth are most pronounced among households with access to liquidity and credit, and may therefore lead to much smaller adjustments in spending than income shocks during the pandemic.

How do these patterns relate to other findings on the consumption responses to the COVID-19 pandemic? The average reduction in expected percent spending growth in our sample is lower than the spending cuts documented in other recent work (Andersen et al., 2020; Baker et al., 2020; Coibion et al., 2020b). Moreover, Cox et al. (2020) document that households' initial spending responses were uncorrelated with income shocks. While these studies examine immediate spending responses at the onset of the pandemic, we provide evidence on expected spending growth over the entire year 2020. One way to reconcile these findings is that while the pandemic first evolved as a supply-side shock, households expect it to unfold as a demand-side shock in the course of the year. 


\subsubsection{Expected household debt}

Survey participants also report whether their expectations about outstanding household debt by the end of 2020 are altered by the current crisis. Overall, 36 percent of respondents report that they expect their household to have more debt outstanding by the end of the year as a result of the current crisis, while 11 percent say they expect lower debt. The bottom row of Figure 3 shows that the fractions of households expecting higher debt are substantial across groups, but more pronounced among those with lower net wealth, income, or those in younger age groups.

Table 3 column 4 shows that both wealth and income shocks are associated with a significantly higher tendency to report upward adjustments in expected outstanding household debt at the end of 2020. This suggests that households tend to smooth shocks to economic resources during the pandemic by taking out more debt or by postponing the repayment of debt. ${ }^{18}$ The top row of Figure A13 shows that income shocks are associated with upward adjustments in expected household debt particularly among those with lower incomes or higher age. We find no significant heterogeneity in the effect of wealth shocks on expectations about debt.

\subsubsection{Expected labor supply}

In addition, 53 percent and 44 percent of respondents in the labor force as of January report that the current crisis increases their desired working hours in the next years or their expected retirement age, respectively. As shown in Figure 4, upward adjustments in expected labor supply are pronounced across groups. However, those in lower net wealth or income quintiles or in younger age groups are more likely to increase their expectations about desired working hours, while increases in expected retirement age are more frequent in the middle of the wealth and income distributions and among older respondents. Naturally, younger households have more time to make up for lost wealth

\footnotetext{
${ }^{18}$ Households may choose to take out a loan in order to make ends meet after being hit by income shocks. Wealth shocks could have a direct effect on household debt levels if households postpone the repayment of debt such as mortgages in response to wealth shocks, or if they expect to make smaller down payments on planned major purchases. Alternatively, wealth shocks could make people more pessimistic about the overall situation of their household going forward through experiential learning (Kuchler and Zafar (2019); Malmendier and Nagel (2011); see Table 4).
} 
and income and may therefore be less likely to adjust their retirement expectations. These findings point to an increase in labor supply in the US in the coming years.

Coibion et al. (2020b) document that many workers who lost their job in early 2020 dropped out of the labor force by retiring early, particularly older individuals. Consistent with their findings, some of our respondents report downward adjustments to their expected retirement age due to the crisis, and the propensity to do so is twice as high for people who report to have lost their jobs over the crisis (6 percent vs 3 percent), and highest for newly unemployed of age 55 and higher.

Moreover, Table 3 columns 5 and 6 show that both wealth and income shocks are associated with a significantly higher tendency to report upward revisions of expected desired working hours in the next years and expected retirement age. For instance, a one percentage point larger shock to retirement wealth is associated with a 0.43 percentage point higher likelihood of upward adjusting expected retirement age, while a one percentage point larger shock to net household income during the first quarter has an effect of 0.19 percentage points. Together, the average shocks in our sample to financial wealth inside and outside retirement accounts, and to net household income of $-11,-8$, and -5 percent predict a 15 percentage points higher probability of upward adjusting the expected retirement age. This implies that incurred wealth and income shocks can account for one third of the overall increase in expected retirement age due to the coronavirus crisis. ${ }^{19}$ Figure A15 displays these regressions in the form of binned scatter plots, highlighting that our findings are not driven by outliers. As illustrated in Figures A13 and Figure A14, we find no systematic heterogeneity in the effect of shocks on expected labor supply by economic resources and across demographic groups. Overall, these findings indicate that households plan to make up for wealth and income losses experienced during the crisis by working more in the coming years. Moreover, the pronounced effects of wealth shocks suggest that household exposure to the stock market can lead to swings in labor supply in response to stock market fluctuations, supporting a key mechanism in models of portfolio choice with human capital (Bodie et al., 1992; Boerma and Heathcote, 2019;

\footnotetext{
${ }^{19}$ Given measurement error in the shock variables and potential non-linearities, this can be interpreted as a lower bound.
} 
Gollier, 2002).

Taken together, our third main result is the following:

Result 3. Larger wealth and income shocks are associated with greater adjustments to planned economic activity. Income shocks strongly affect expected spending, while wealth shocks only have minor effects. However, households plan to make up for lost income and wealth by increasing their desired working hours over the coming years and by increasing their retirement age. Income and wealth shocks are also associated with upward adjustments in expected household debt.

\section{Main results: Effects of expected stock market recovery duration on expectations and plans}

In the previous section we have explored how capital losses incurred during the crash affect households' expectations about their medium- to long-term economic outcomes. In this section we study the formation of respondents' expectations about the further development of the stock market, and how those expectations causally shape their outlook for their own wealth and economic plans.

\subsection{Descriptive evidence on beliefs about recovery}

The survey asks respondents in which calendar year they expect the US stock market to have recovered to its pre-crisis level of January 2020. Respondents who report capital losses or income losses during the first quarter of 2020 also report the calendar year in which they expect their own wealth or income to have recovered, including options that they expect their wealth or income never to recover. The wording of the questions is agnostic about whether respondents expect further decreases in the stock market or their own wealth or whether they believe those outcomes to be on an increasing path at the time of the survey.

As shown in the left column of Figure A16, respondents who have made financial losses estimate that it will take 1.68 years for the stock market and 1.58 years for their own household wealth to recover to pre-crisis levels, and these patterns are fairly uniform 
across groups, aside from younger respondents expecting a longer stock market recovery duration. ${ }^{20}$ Households who incurred income shocks expect their incomes to take 1.74 years to recover on average, with the lowest income, youngest, and oldest groups of respondents predicting a longer income recovery duration. The right column of Figure A16 documents that the fraction of respondents expecting their own financial wealth never to recover is highest among those with low net wealth or low net income, as well as among older respondents.

\subsection{Determinants of stock market and own wealth expectations}

What is driving households' expectations about the stock market and the development of their own wealth after a crash? Table 4 explores the role of different factors previous literature has identified as playing a crucial role in expectation formation. ${ }^{21}$

We start with the role of personal experiences, which have been shown to be an important determinant of expectations about the stock market (Malmendier and Nagel, 2011), house prices (Kuchler and Zafar, 2019) or inflation (D'Acunto et al., 2019b; GoldfaynFrank and Wohlfart, 2019; Malmendier and Nagel, 2016). Individuals who have experienced more negative income shocks expect the stock market to take more time to recover (column 1), expect lower stock returns (column 2), and perceive a higher probability of extreme negative stock market returns of below -30 percent (column 4) and a lower probability of very high stock returns (column 5). These patterns are somewhat weaker for financial wealth losses in the recent crash. Naturally, individuals who were hit harder expect a longer recovery duration for their own financial situation (columns 6-7). However, they are also more likely to expect a further worsening of their household's financial situation over the next year (column 8).

We also study the role of personal experiences made in historic crashes. Having experienced losses in the stock market during the Financial Crisis 2007-9 is associated

\footnotetext{
${ }^{20}$ Respondents who expect their wealth or income never to recover are excluded from the left column. The figure is based on respondents in the PureControl arm, who were not asked about nor received any information on the recovery duration in a previous crash.

${ }^{21}$ Table 4 reports multivariate regressions of these expectations on a set of covariates. It uses only respondents in the four control groups, who have not received information. Table A6 replicates the table using only respondents in the pure control group, who have not received any questions or information on past crashes.
} 
with more pessimistic expectations about the stock market and regarding the development of own wealth, while the patterns are less consistent for losses incurred in earlier crashes such as the burst of the Dot-com bubble or the Black Monday. This is in line with the previously documented recency bias in the role of personal experiences in macroeconomic expectation formation (Kuchler and Zafar, 2019; Malmendier and Nagel, 2011). These findings highlight that personal experience seems to be an important driver of individuals' expectations in the time following a market crash. Moreover, this evidence offers an explanation for the more pronounced tendency to reduce stock investments among those who have lost wealth during past crashes (see section 4.1).

Men predict shorter recovery durations of the market and of their own wealth and are significantly more optimistic about their household's financial prospects, in line with previously documented gender gaps in macroeconomic expectations (D'Acunto, 2020; D'Acunto et al., 2020). Finally, Republicans expect the recovery to be 0.7 years shorter compared to Democrats, they predict a six percentage point higher stock return, and are more optimistic about their own household's financial situation. These patterns are in line with earlier findings documenting strong partisan bias in reported survey expectations (Mian et al., 2018) and a partisan gap in stock investment following the presidential election of Donald Trump (Meeuwis et al., 2019). ${ }^{22}$ Given the pronounced heterogeneity in expectations according to political affiliation it seems surprising that we did not detect significant differences between Republicans and Democrats in active adjustments to risktaking in section 4.1 .

Result 4. Experienced losses in past crashes, gender as well as political affiliation are important determinants of beliefs about the recovery from the February/March 2020 stock market crash.

\footnotetext{
${ }^{22}$ Another driver of this result may be geographic and urban heterogeneity in social distancing and exposure to the coronavirus pandemic. Related research suggest that differences in exposure affect expectations and outcomes, and exposure and combative measures vary significantly geographically (Baker et al., 2020; Bu et al., 2020; Coibion et al., 2020b; Kuchler et al., 2020).
} 


\subsection{Learning from information about past crashes}

Our survey includes a short experimental section in which respondents report their prior beliefs about the duration of the recovery in the case of a historical stock market crash, and random subsets of respondents receive information on the actual recovery duration. We use this experimental setup i) to shed light on the role of beliefs about past crashes in shaping respondents' expectations in the current situation; and ii) to provide causal evidence on the role of stock market expectations in shaping respondents' outlook for their own situation and their planned economic behavior.

Stock market crashes are rare events, and can have a variety of different origins, ranging from corrections to the value of firms or industries to problems in the housing market or shocks to the real economy. Given the unprecedented speed and strength of the current crash, and given its origin in the first world-wide pandemic for more than 100 years, the historical database for predicting the further development of the stock market is arguably limited. Do our respondents believe that the current crash is "unique" in the sense that it is not comparable to previous crashes, or do they consider facts about historical crashes to be relevant for the current situation?

Figure 5 displays beliefs about the recovery duration from the current crash and from past crashes using respondents in the relevant survey arms. 65.8 percent underestimate the duration of recovery in the case of the Financial Crisis 2007-9 (5 1/2 years, top-right) and 63.2 percent do so for the Dot-com bubble in 2000 (7 years, bottom-left), but a majority of 79.4 percent overestimate the duration of recovery from the Black Monday crash 1987 (2 years, bottom-right). Respondents in the pure control group, who have not received any questions or information on past crises, predict a recovery duration of 1.9 years for the current crash. However, given differences in the scales on which these beliefs are elicited, one should interpret these differences with caution. ${ }^{23}$

Given these patterns in prior beliefs, the information that random subsets of our respondents receive can be seen as pessimistic (in the cases of the longer recovery durations

\footnotetext{
${ }^{23}$ Specifically, beliefs about historical crashes are elicited asking for number of years, while beliefs about the current situation are elicited asking for calendar year. The different elicitation scales have important advantages for our experimental analysis, as they mitigate concerns related to numerical anchoring.
} 
of the Financial Crisis 2007-9 or the Dot-com bubble 2000) or as optimistic (in case of the shorter recovery duration following the Black Monday crash). How do respondents change their beliefs about the current situation when provided with information on the length of recovery from past crashes? In Table 5 we regress respondents' post-treatment expectations about the stock market on dummy variables indicating whether they have received information. Panels A, D and G use all respondents in the relevant arms. Panels $\mathrm{B}, \mathrm{E}$ and $\mathrm{H}$ restrict the analysis to respondents who underestimate actual historic recovery durations in the case of the "pessimistic" Financial Crisis and Dot-com bubble treatments, or to respondents who overestimate the time until recovery in the "optimistic" Black Monday treatment. Panels C, F and I use only over- or underestimators who report positive stockholdings as of January 2020. The "pessimistic" treatments providing information on the Financial Crisis or the Dot-com bubble increase respondents' expected recovery duration by between 1.3 and 2.3 years, while the "optimistic" treatment providing information on the Black Monday crash reduces the expected recovery duration by about one year (column 1). Given a standard deviation of expected recovery beliefs of 3.2 years, the economic magnitude of these effects is substantial.

The treatments also lead to shifts between 0.1 and 0.3 standard deviations in respondents' extent of agreement to verbal statements describing the severity of the current crash (columns 2-4). ${ }^{24}$ The Financial Crisis and the Black Monday treatments move respondents' expected stock returns by up to -3 and up to 2 percentage points, respectively (column 5), and change the subjective probabilities assigned to extreme return realizations accordingly (columns 7-8). The size of these effects amounts to about half of the strong partisan gap in expectations documented in Table 4. Most of the coefficient estimates increase in absolute size when restricting the sample to over- or under-estimators, although we lack the power to meaningfully explore differences in effect sizes across groups. ${ }^{25}$

\footnotetext{
${ }^{24}$ Specifically, the treatments change respondents' agreement on 7-point categorical scales (which we z-score using the mean and standard deviation in our sample) with the following statements: "The outbreak of the coronavirus will keep US stock prices below their January 2020 levels for many years." (column 2); "The outbreak of the coronavirus has set the level of the stock market back by many years." (column 3); "The US stock market will have recovered by the end of the year 2020." (column 4).

${ }^{25}$ The experimental findings on the effect of shocks to beliefs about past crashes are mirrored in correlations between priors about historical recovery durations and current stock market expectations using respondents in the control groups, which are reported in Table A7.
} 
Taken together, the strong effects of information on respondents' expectations about the stock market highlight that households continue to form expectations based on their beliefs about stock market developments in the past, even in very unique and unprecedented situations. Moreover, these findings imply that information about historical stock market developments had not been fully incorporated into respondents' prior expectations, pointing to an important role of information frictions in the formation of households' stock market expectations. This is consistent with models in which information is costly to acquire or to process (Abel et al., 2007; Alvarez et al., 2012), which may result in a lack of preparation particularly for rare events (Maćkowiak and Wiederholt, 2018).

\subsection{Expected stock market recovery and own outlook and plans}

Do expectations about the further development of the stock market have similar effects on households' economic plans as capital losses already incurred during the crash (see section 4.1)? Our randomized provision of information about past crashes generates exogenous variation in our respondents' recovery expectations. We exploit this setting to shed light on the causal effects of households' stock market expectations on their outlook regarding their own wealth and their plans about investment, spending, debt and labor supply.

In Table 6 we regress different outcomes on respondents' expected recovery duration of the stock market and our baseline set of control variables. First, the table shows OLS estimations using respondents in all control groups, who have not received any information (Panels A and B). Second, the table shows 2SLS estimations, where the respondents' expected recovery duration is instrumented with the dummy for the relevant information treatment assignment, as well as the corresponding OLS estimates in the relevant subsamples (Panels C-H). Panels B-H restrict the sample to stockholders as of January 2020, and Panels C-H are restricted to the majorities of respondents who overestimated (Panels C-F) or who underestimated (Panels G-H) the duration of recovery from the corresponding historical crash. ${ }^{26}$ In addition, Table A9 displays OLS estimates

\footnotetext{
${ }^{26}$ This increases the strength of our first stage estimates and ensures that the monotonicity assumption (that the first stage shifts all respondents' beliefs in the same direction) holds. Table A8 presents reduced form estimates of the effects of the information treatments on wealth expectations and plans.
} 
for different subgroups using all control groups. ${ }^{27}$

Expectations about own wealth Respondents' beliefs about the recovery duration of the stock market are strongly correlated with their expectations about their own wealth (Table 6 column 1). Among stockholders, a one year longer expected stock market recovery translates into a 0.45 years longer expected recovery of respondents' own wealth and a 0.09 standard deviations reduction in people's financial prospects for their household (column 2). For comparison, already incurred financial wealth losses of 11 percent (the mean losses in our sample), are associated with a longer expected recovery of own wealth by 0.39 years and a reduction in household's financial prospects by 0.06 of a standard deviation (see Table 4). The 2SLS estimates exploiting the experimental variation are mostly highly significant and of similar size as the OLS estimates. Table A9 columns 1-2 show that stock market recovery expectations play a significantly larger role for the wealth expectations of older stockholders, those with lower net wealth and for men. These findings indicate that beliefs about the further development of the stock market play a substantial causal role in shaping households' wealth expectations, particularly among those who have less time during their working life to make up for these losses.

Investment plans Do people's expectations about the further development of the stock market also affect their planned investment behavior? A substantial literature has studied correlations between subjective expectations and stock market participation or the equity portfolio share (Ameriks et al., 2019; Amromin and Sharpe, 2014; Dominitz and Manski, 2007; Giglio et al., 2020a; Hudomiet et al., 2011; Vissing-Jørgensen, 2002). While our survey only contains self-reported investment plans, the randomized information provision allows us to provide, to the best of our knowledge, the first causal evidence on the role of subjective return expectations in (planned) investment decisions. Respondents who expect a longer recovery are 0.58 percentage points more likely to plan to increase the share of their portfolio invested in equities and 0.53 percentage points less likely to plan a reduction (Table 6 columns 3 and 4). The results of the IV estimations exploiting the

\footnotetext{
${ }^{27}$ We are not powered to conduct IV estimations on subsamples due to the smaller sample available for each instrument.
} 
"pessimistic" Financial Crisis and Dot-com instruments are insignificant. However, when we use the "optimistic" Black Monday instrument we estimate significant causal effects of expected recovery duration on plans to increase and to decrease the share invested in stocks by -4.3 and by 3.7 percentages points, respectively. Average tendencies to plan increases or decreases are 28 and 23 percent in our sample, highlighting that expectations seem to play an important role in shaping investment plans following a crash. Table A9 columns 3-4 show that the association of expectations and investment plans seems to be fairly uniform across groups. Future research could link survey and administrative data to examine whether investment decisions are more elastic to beliefs during times of market turmoil than during more tranquil times, when the role of beliefs seems to be moderate (Giglio et al., 2020a).

Expected spending and debt How do people's expectations about the stock market recovery affect their plans in other domains? Expectations about the duration of the stock market recovery are negatively correlated with respondents' expectations about their spending growth (Table 6 column 5). However, none of the causal estimates from the 2SLS regressions are significant. This is in line with our earlier finding that financial wealth shocks incurred during the February/March 2020 stock market crash are not reflected in significant changes in expected spending growth (see section 4.2 and Figure A10). More pessimistic expectations about the stock market recovery are associated with a significantly higher tendency to report upward adjustments in expected household debt for the end of 2020 (column 6). However, this correlation turns insignificant once we restrict the sample to stockholders. Among the causal estimates only the Black Monday treatment gives a marginally significant estimate. We interpret this as mixed evidence for an effect of stock market expectations on expectations about household debt

Expected labor market activity Portfolio choice models including human capital predict that households should adjust their labor supply in response to wealth fluctuations (Bodie et al., 1992; Boerma and Heathcote, 2019; Gollier, 2002). Among stockholders, a one year increase in expected stock market recovery duration is associated with 2 percentage point increases in the tendencies to upward adjust expectations about desired working hours 
over the next years (Table 6 column 7) and about retirement age (column 8). Moreover, using the "pessimistic" Financial Crisis instrument we find significant causal effects of about 5 percentage points on the tendency to upward adjust these expectations. ${ }^{28}$ The economic magnitudes of these effects is substantial, corresponding to the effects of having experienced a shock to retirement financial wealth of 21 or 13 percentage points, respectively. Table A9 columns 7-8 highlight that the effects of stock market expectations on planned labor market activity are particularly pronounced among those with lower net wealth, suggesting that these households' long-term plans did not include a buffer for the case of large wealth losses during a crash. To the best of our knowledge our experimental findings are the first direct causal evidence on the role of expectations about financial markets in shaping people's long-term plans regarding work. This highlights that rising exposure to the stock market among households can have important consequences for households' long-term planning and for labor markets.

Taken together, these results suggest that not only wealth shocks incurred during the crash, but also beliefs about the performance of the stock market in the next years play an important role in shaping US households' expectations about their own economic situation and plans. Our fifth main result is the following:

Result 5. Households' beliefs about the duration of recovery from the stock market crash are strongly correlated with expectations about their own wealth, their planned investment behavior and their long-term expectations about labor market activity. Results from IV estimations exploiting randomized information provision suggest that part of these effects are causal.

\subsection{Robustness}

Cross-learning Respondents update their expectations about their own wealth and their economic plans in response to the provided information, plausibly through direct effects working through their stock market expectations. Alternatively, there could be crosslearning in the sense that respondents may update their beliefs about overall GDP growth

\footnotetext{
${ }^{28}$ While we find no significant effects using the other instruments, we note that also the OLS estimates in the relevant arms are insignificant.
} 
and labor markets in response to the information. We view such cross-learning as a natural by-product of changes in expectations induced by random information provision. For instance, changes in stock return expectations in panel data from existing surveys tend to be associated with changes in GDP growth expectations (Amromin and Sharpe, 2014; Giglio et al., 2020a), raising the question whether it would be a meaningful exercise to change people's expectations about stock returns, while holding fixed their expectations about growth. However, we do not believe that cross-learning about GDP growth or labor markets is the main driver behind our findings. First, we find mostly insignificant treatment effects when we restrict our sample to non-stockholders. Second, we find only minor effects on respondents' income expectations due to our information treatments. These results are unreported for brevity but available upon request.

Numerical anchoring One concern about our experimental findings could be unconscious numerical anchoring on the provided information (Cavallo et al., 2017; Coibion et al., 2019b). We believe that in our setting this concern is likely much less severe than in other settings because the response scales of the post-treatment questions are different to the scale of the provided information (calendar year, 7-point agreement scale, or density distribution instead of number of years). Moreover, previous studies have documented only small changes of reported survey expectations in response to the provision of irrelevant numerical anchors (Coibion et al., 2019b; Roth and Wohlfart, 2019).

Experimenter demand effects Relatedly, our experimental findings could be driven by experimenter demand effects, i.e. by subjects guessing the experimental hypothesis and reporting posterior beliefs such as to confirm with the hypothesis. We think that our experimental findings are unlikely driven by demand effects for three reasons: i) our study is fully based on a between-subject design, where no question is asked twice in the survey (i.e. both before and after the treatment, as in within-subject designs), arguably mitigating demand effects; ii) at the end of our survey we explicitly asked our respondents to report their beliefs about the purpose of the study, and less than 10 respondents suspected the survey to contain some form of experimental treatment (Table A10); iii) experimenter demand effects have been shown to be of limited importance in comparable 
online surveys (de Quidt et al., 2018).

\section{Implications and conclusion}

With increasing stock market participation, households around the world have become more exposed to stock market downturns. We have conducted a survey on a representative sample of more than 8,000 US households, which offers a comprehensive real-time snapshot of US households' finances and expectations about the future in the time following one such crash. We document that shocks to households' financial wealth due to the COVID-19 stock market decline tend to be negatively correlated with income shocks experienced during the early stages of the pandemic. While about half of all stock owners made adjustments to their investments in the course of the crash, there was no systematic tendency to rebalance portfolios in response to the passive reduction in equity portfolio shares. Financial wealth shocks are associated with adjustments in expectations about household debt, retirement age and desired working hours, but have no substantial effect on expected spending. Finally, beliefs about the recovery of the stock market causally shape individuals' expectations about their own wealth and their plans regarding investment, debt and labor market activity in the future.

Our findings highlight that exposure to stock market downturns is concentrated among groups who tend to be less exposed to income shocks and job losses during recessions. Moreover, when households experience shocks to their retirement wealth during a stock market crash, they plan to make up for it by increasing their labor supply in the following years and by postponing their retirement age. Similarly, their expectations about the stock market recovery directly shape their expectations about own labor market activity. This implies that households who invest their retirement wealth in stocks accept fluctuations in their long-term expectations about retirement age and working life, in line with a key mechanism in portfolio choice models including human capital (Bodie et al., 1992; Gollier, 2002). Households who are unwilling to accept such fluctuations may be reluctant to invest in stocks, contributing to the widely-documented non-participation in the stock market across groups (Guiso and Sodini, 2013; Haliassos and Bertaut, 1995). Moreover, 
since for older households it is more difficult to make up for wealth losses by extending labor supply, this mechanism can explain reductions in the equity share as people age. At a macro level, our results suggest that increasing household exposure to the stock market may generate a link from financial market developments to medium-term swings in labor supply.

Our results have several more specific implications for the economic and financial consequences of the COVID-19 pandemic. First, in order to adequately gauge the shortrun impact of the current crisis on inequality in overall economic resources one should consider both income shocks and wealth shocks. Second, our findings on substantial increases in expected retirement age or desired working hours suggest that there will be an increase of labor supply in the US after the lockdowns are lifted, as households are trying to make up for the lost wealth and income. This could put downward pressure on wages and further aggravate economic hardships for those in the bottom of the distribution. Third, beliefs about the recovery of the stock market seem to be central to individuals' subjective economic prospects and expected decisions, indicating that policymakers may stimulate the economic recovery after the lockdown by managing these expectations.

\section{References}

Abel, Andrew B, Janice C Eberly, and Stavros Panageas, "Optimal Inattention to the Stock Market," American Economic Review, 2007, 97 (2), 244-249.

Adams-Prassl, Abi, Teodora Boneva, Marta Golin, and Christopher Rauh, "Inequality in the Impact of the Coronavirus Shock: Evidence from Real Time Surveys," Working Paper, 2020.

Agnew, Julie, Pierluigi Balduzzi, and Annika Sundén, "Portfolio Choice and Trading in a Large 401(k) Plan," American Economic Review, March 2003, 93 (1), 193-215.

Alvarez, Fernando, Luigi Guiso, and Francesco Lippi, "Durable Consumption and Asset Management with Transaction and Observation Costs," American Economic Review, 2012, $102(5), 2272-2300$.

Ameriks, John and Stephen P Zeldes, "How do Household Portfolio Shares Vary with Age?," Working Paper, 2004.

_ , Gábor Kézdi, Minjoon Lee, and Matthew D Shapiro, "Heterogeneity in Expectations, Risk Tolerance, and Household Stock Shares: The Attenuation Puzzle," Journal of Business $\&$ Economic Statistics, 2019, pp. 1-27. 
Amromin, Gene and Steven A Sharpe, "From the Horse's Mouth: Economic Conditions and Investor Expectations of Risk and Return," Management Science, 2014, 60 (4), $845-866$.

Andersen, Asger Lau, Emil Toft Hansen, Niels Johannesen, and Adam Sheridan, "Consumer Responses to the COVID-19 Crisis: Evidence from Bank Account Transaction Data," Working Paper, 2020.

Andersen, Steffen, Tobin Hanspal, and Kasper Meisner Nielsen, "Once Bitten, Twice Shy: The Power of Personal Experiences in Risk Taking," Journal of Financial Economics, 2019, 132 (3), 97-117.

Armantier, Olivier, Scott Nelson, Giorgio Topa, Wilbert van der Klaauw, and Basit Zafar, "The Price Is Right: Updating Inflation Expectations in a Randomized Price Information Experiment," Review of Economics and Statistics, 2016, 98 (3), 503-523.

Armona, Luis C, Andreas Fuster, and Basit Zafar, "Home Price Expectations and Behavior: Evidence from a Randomized Information Experiment," The Review of Economic Studies, 2018, 86 (4), 1371-1410.

Bachmann, Rüdiger, Tim O Berg, and Eric R Sims, "Inflation Expectations and Readiness to Spend: Cross-Sectional Evidence," American Economic Journal: Economic Policy, 2015, 7, 1-35.

Bailey, Michael, Ruiqing Cao, Theresa Kuchler, and Johannes Stroebel, "The Economic Effects of Social Networks: Evidence from the Housing Market," Journal of Political Economy, 2017, 126 (6), 2224-2276.

Baker, Scott, R.A. Farrokhnia, Steffen Meyer, Michaela Pagel, and Constantine Yannelis, "How Does Household Spending Respond to an Epidemic? Consumption During the 2020 COVID-19 Pandemic," Working Paper, 2020.

Bick, Alexander and Adam Blandin, "Real Time Labor Market Estimates During the 2020 Coronavirus Outbreak," Working Paper, 2020.

Bilias, Yannis, Dimitris Georgarakos, and Michael Haliassos, "Portfolio Inertia and Stock Market Fluctuations," Journal of Money, Credit and Banking, 2010, 42 (4), 715-742.

Binder, Carola, "Coronavirus Fears and Macroeconomic Expectations," Review of Economics and Statistics, 2020.

- and Alex Rodrigue, "Household Informedness and Long-Run Inflation Expectations: Experimental Evidence," Southern Economic Journal, 2018.

Bodie, Zvi, Robert C. Merton, and William F. Samuelson, "Labor Supply Flexibility and Portfolio Choice in a Life Cycle Model," Journal of Economic Dynamics and Control, 1992, $16(3), 427-449$.

Boerma, Job and Jonathan Heathcote, "Illiquid Wealth and the Timing of Retirement," Working Paper, 2019.

Bräuer, Konstantin, Andreas Hackethal, and Tobin Hanspal, "Consuming Dividends," Working Paper, 2020. 
Brunnermeier, Markus K and Stefan Nagel, "Do Wealth Fluctuations Generate TimeVarying Risk Aversion? Micro-Evidence on Individuals," American Economic Review, 2008, 98 (3), 713-36.

Bu, Di, Tobin Hanspal, Yin Liao, and Yong Liu, "Risk Taking During a Global Crisis: Evidence from Wuhan," Working Paper, 2020.

Calvet, Laurent E., John Y. Campbell, and Paolo Sodini, "Fight or Flight? Portfolio Rebalancing by Individual Investors*," The Quarterly Journal of Economics, 02 2009, 124 (1), 301-348.

Cavallo, Alberto, Guillermo Cruces, and Ricardo Perez-Truglia, "Inflation Expectations, Learning and Supermarket Prices: Evidence from Field Experiments," American Economic Journal: Macroeconomics, 2017, 9 (3), 1-35.

Christelis, Dimitris, Dimitris Georgarakos, Tullio Jappelli, Luigi Pistaferri, and Maarten van Rooij, "Wealth Shocks and MPC Heterogeneity," Working Paper, 2019.

Coibion, Olivier, Dimitris Georgarakos, Yuriy Gorodnichenko, and Maarten van Rooij, "How Does Consumption Respond to News about Inflation? Field Evidence from a Randomized Control Trial," Working Paper, 2019.

_, , , , and Michael Weber, "Forward Guidance and Household Expectations," Working Paper, 2020.

_, Yuriy Gorodnichenko, and Michael Weber, "Monetary Policy Communications and Their Effects on Household Inflation Expectations," Working Paper, 2019.

_ , _ , and _ , "The Cost of the COVID-19 Crisis: Lockdowns, Macroeconomic Expectations, and Consumer Spending," Working Paper, 2020.

_ , _ , and _ , "Labor Markets during the Covid-19 Crisis: A Preliminary View," Working Paper, 2020.

_, _, and Saten Kumar, "How Do Firms Form Their Expectations? New Survey Evidence," American Economic Review, September 2018, 108 (9), 2671-2713.

Cox, Natalie, Diana Farrell, Peter Ganong, and Fiona Greig, "The Initial Household Spending Response to COVID-19: Evidence from Credit Card Transactions," Working Paper, 2020.

D’Acunto, Francesco, "Identity and Choice under Risk," Working Paper, 2020.

_ , Daniel Hoang, and Michael Weber, "Managing Households' Expectations with Simple Economic Policies," Working Paper, 2019.

D'Acunto, Francesco, Ulrike Malmendier, and Michael Weber, "Gender Roles and the Gender Expectations Gap," Working Paper, 2020.

D’Acunto, Ulrike Malmendier, Juan Ospina, and Michael Weber, "Exposure to Daily Price Changes and Inflation Expectations," Working Paper, 2019.

Das, Sreyoshi, Camelia M Kuhnen, and Stefan Nagel, "Socioeconomic Status and Macroeconomic Expectations," Working Paper, 2017. 
de Quidt, Jonathan, Johannes Haushofer, and Christopher Roth, "Measuring and Bounding Experimenter Demand," American Economic Review, 2018, 108 (11), 32663302 .

Di Maggio, Marco, Amir Kermani, and Kaveh Majlesi, "Stock Market Returns and Consumption," Journal of Finance, 2019.

Dietrich, Alexander, Keith Kuester, Gernot Müller, and Raphael Schoenle, "News and Uncertainty about COVID-19: Survey Evidence and Short-Run Economic Impact," Working Paper, 2020.

Dominitz, Jeff and Charles F Manski, "Expected Equity Returns and Portfolio Choice: Evidence from the Health and Retirement Study," Journal of the European Economic Association, 2007, 5 (2-3), 369-379.

Fetzer, Thiemo, Lukas Hensel, Johannes Hermle, and Christopher Roth, "Coronavirus Perceptions and Economic Anxiety," Working Paper, 2020.

Fuster, Andreas, Greg Kaplan, and Basit Zafar, "What Would You Do With \$500? Spending Responses to Gains, Losses, News and Loans," Working Paper, 2020.

_ , Ricardo Perez-Truglia, Mirko Wiederholt, and Basit Zafar, "Expectations with Endogenous Information Acquisition: An Experimental Investigation," Working Paper, 2019 .

Giglio, Stefano, Matteo Maggiori, Johannes Stroebel, and Stephen P Utkus, "Five Facts About Beliefs and Portfolios," Working Paper, 2020.

_ , _ , , and _ , "Inside the Mind of a Stock Market Crash," Working Paper, 2020.

Goldfayn-Frank, Olga and Johannes Wohlfart, "Expectation Formation in a New Environment: Evidence from the German Reunification," Journal of Monetary Economics, 2019 .

Gollier, Christian, "Time Diversification, Liquidity Constraints, and Decreasing Aversion to Risk on Wealth," Journal of Monetary Economics, 2002, 49 (7), 1439-1459.

Gormsen, Niels Joachim and Ralph SJ Koijen, "Coronavirus: Impact on Stock Prices and Growth Expectations," Working Paper, 2020.

Greenwood, Robin and Andrei Shleifer, "Expectations of Returns and Expected Returns," The Review of Financial Studies, 2014, 27 (3), 714-746.

Guiso, Luigi and Paolo Sodini, "Household Finance: An Emerging Field," in "Handbook of the Economics of Finance," Vol. 2, Elsevier, 2013, pp. 1397-1532.

_ , Paola Sapienza, and Luigi Zingales, "Time Varying Risk Aversion," Journal of Financial Economics, 2018, 128 (3), 403-421.

Haliassos, Michael and Carol C. Bertaut, "Why do so Few Hold Stocks?," The Economic Journal, 1995, 105 (432), 1110-1129.

Hoynes, Hilary, Douglas L Miller, and Jessamyn Schaller, "Who Suffers During Recessions?," The Journal of Economic Perspectives, 2012, 26 (3), 27-47. 
Hudomiet, Peter, Gábor Kézdi, and Robert J Willis, "Stock Market Crash and Expectations of American Households," Journal of Applied Econometrics, 2011, 26 (3), $393-415$.

Imas, Alex, "The Realization Effect: Risk-taking After Realized versus Paper Losses," American Economic Review, 2016, 106 (8), 2086-2109.

Jappelli, Tullio and Mario Padula, "The Consumption and Wealth Effects of an Unanticipated Change in Lifetime Resources," Management Science, 2015, 62 (5), 1458-1471.

Kuchler, Theresa and Basit Zafar, "Personal Experiences and Expectations about Aggregate Outcomes," Journal of Finance, 2019, 74 (5), 2491-2542.

_, Dominic Russel, and Johannes Stroebel, "The Geographic Spread of COVID-19 Correlates with Structure of Social Networks as Measured by Facebook," Working Paper, 2020.

Kuhn, Moritz, Moritz Schularick, and Ulrike Steins, "Income and Wealth Inequality in America," Journal of Political Economy, 2019.

Laudenbach, Christine, Benjamin Loos, Jenny Pirschel, and Johannes Wohlfart, "The Trading Response of Individual Investors to Local Bankruptcies," Working Paper, 2020.

Maćkowiak, Bartosz and Mirko Wiederholt, "Lack of Preparation for Rare Events," Journal of Monetary Economics, 2018, 100, 35-47.

Madrian, Brigitte C and Dennis F Shea, "The Power of Suggestion: Inertia in 401 (k) Participation and Savings Behavior," Quarterly Journal of Economics, 2001, 116 (4), 1149-1187.

Malmendier, Ulrike and Stefan Nagel, "Depression Babies: Do Macroeconomic Experiences Affect Risk-Taking?," The Quarterly Journal of Economics, 2011, 126 (1), 373416.

_ and _, "Learning from Inflation Experiences," The Quarterly Journal of Economics, 2016, 131 (1), 53-87.

Meeuwis, Maarten, Jonathan A Parker, Antoinette Schoar, and Duncan I Simester, "Belief Disagreement and Portfolio Choice," Working Paper, 2019.

Mian, Atif, Amir Sufi, and Nasim Khoshkhou, "Partisan Bias, Economic Expectations, and Household Spending," Working Paper, 2018.

Roth, Christopher and Johannes Wohlfart, "How Do Expectations About the Macroeconomy Affect Personal Expectations and Behavior?," Review of Economics and Statistics, 2019.

Vissing-Jørgensen, Annette, "Limited Asset Market Participation and the Elasticity of Intertemporal Substitution," Journal of Political Economy, 2002, 110 (4), 825-853.

Vissing-Jorgensen, Annette, "Perspectives on Behavioral Finance: Does "Irrationality" Disappear with Wealth? Evidence from Expectations and Actions," NBER Macroeconomics Annual, 2003, 18, 139-194. 
Weber, Martin, Elke U Weber, and Alen Nosić, "Who Takes Risks When and Why: Determinants of Changes in Investor Risk Taking," Review of Finance, 2013, 17 (3), $847-883$.

\section{Main figures}


Figure 1: Wealth and income shocks across groups

Panel A: Financial wealth shocks

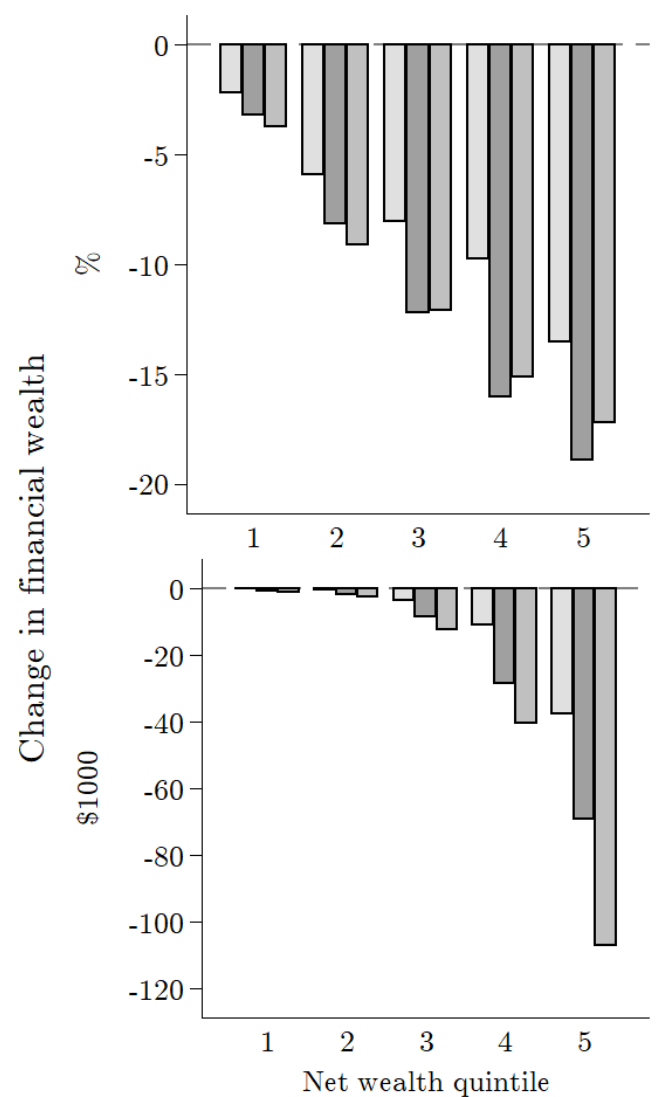

$\square$ Other financial wealth
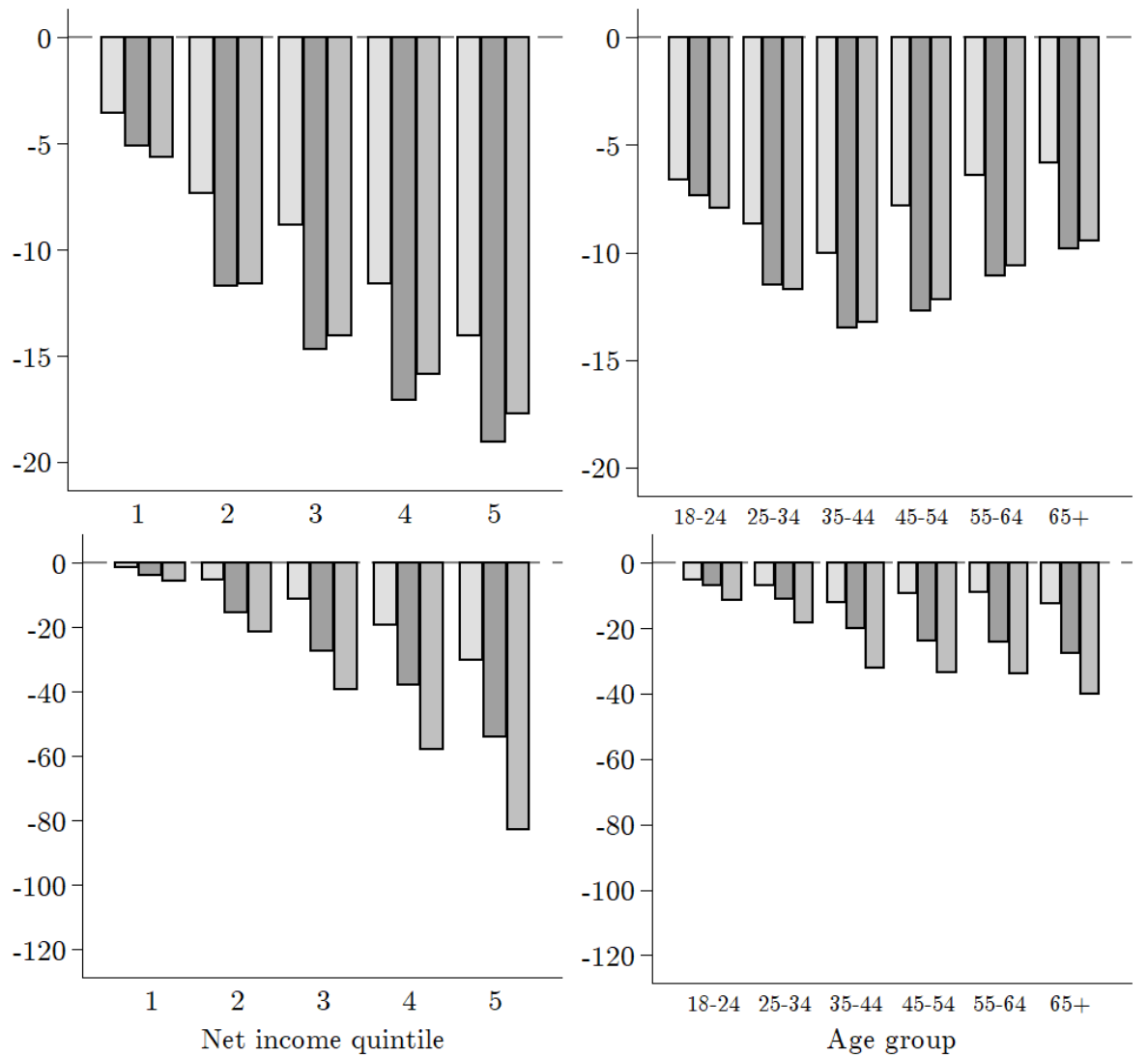

$\square$ Retirement wealth

$\square$ Total financial wealth 
Panel B: Household net income shocks
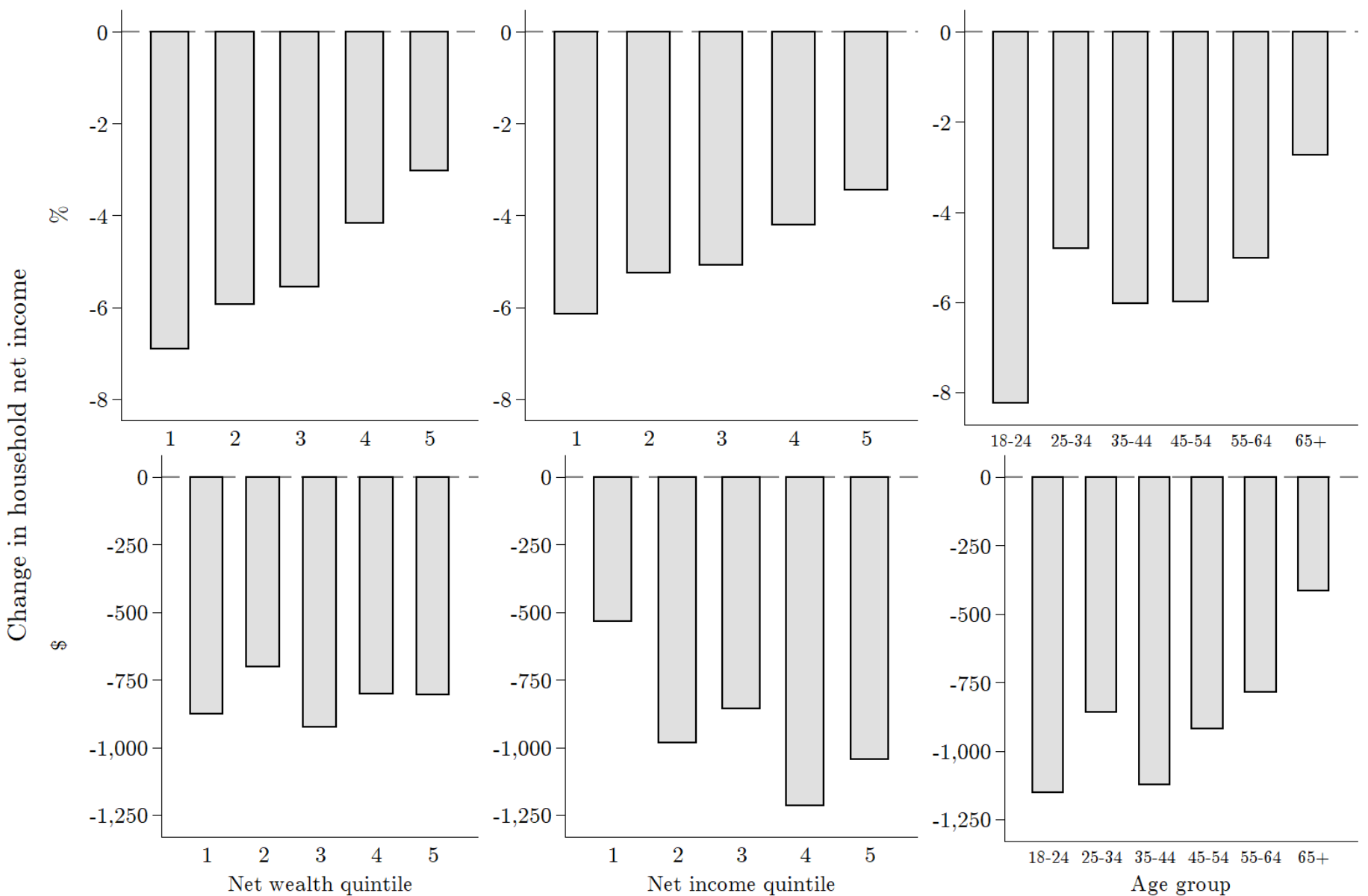

Notes: This figure displays the change in the value of financial assets due to the February/March 2020 stock market drop until the survey date in percentage terms and in USD (Panel A) and unexpected changes in net household incomes during the first quarter of 2020 in percentages and USD (Panel B), by quintile of the pre-crisis net wealth distribution (left column), by quintile of the pre-crisis net income distribution (middle column) and by age group (right column). Changes in the value of household financial assets are displayed separately for financial assets outside of retirement accounts (other financial wealth), for financial assets in retirement accounts, and for the combined value of financial assets. Changes in value of financial assets are net capital losses for the majority of respondents, and net capital gains for a small fraction of respondents. We trim reported shocks to income and financial wealth at the 2nd and 98th percentiles. The sample is the full sample without missings in the relevant survey questions. Note that the average percent reduction in overall financial wealth can be larger than both average percent reductions for the individual components. This is due to the fact that we coded those with no wealth in a given category as having experienced a shock of zero percent in that category. These cases occur particularly in groups with lower wealth holdings. 
Figure 2: Realized and planned adjustments to stock share across groups
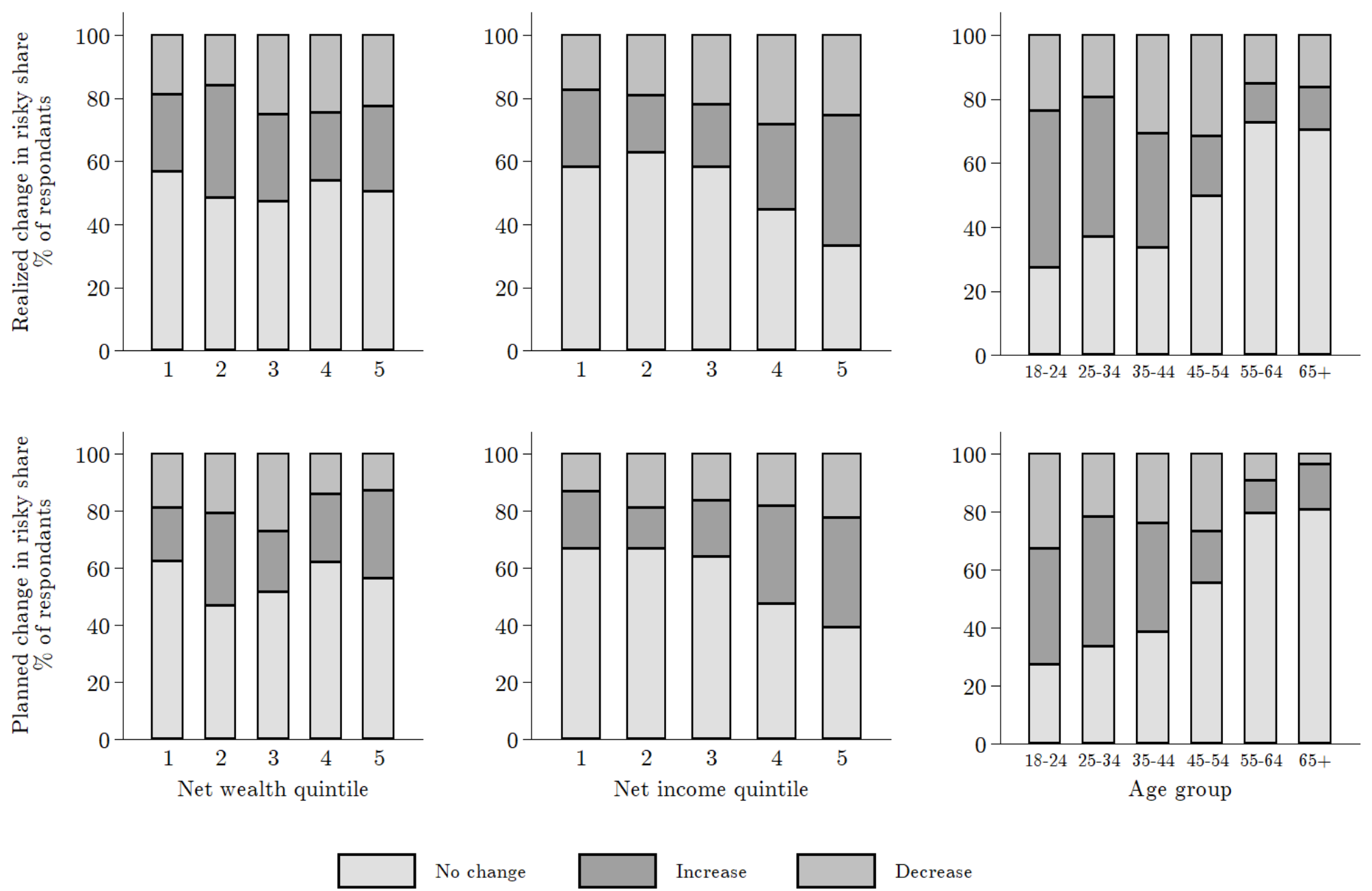

No change
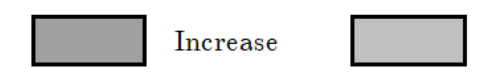

Decrease

Notes: The top row of this figure displays the fractions of pre-crisis stockholders in different groups reporting that they made no active change, actively increased, or actively decreased the share of their overall financial assets (including retirement and non-retirement accounts) that is invested in the stock market since the beginning of the crisis, while the bottom row plots the percent of respondents who stated that they are planning to make no change, increase, or decrease their investment in the following weeks. The fractions are plotted by quintile of the pre-crisis net wealth distribution (left), quintile of the pre-crisis net income distribution (middle), and age group (right). The sample consists of all pre-crisis stock investors in the pure control group, who have not received any questions or information on past crashes before answering to the questions on investment behavior. 
Figure 3: Changes in expected spending and debt across groups
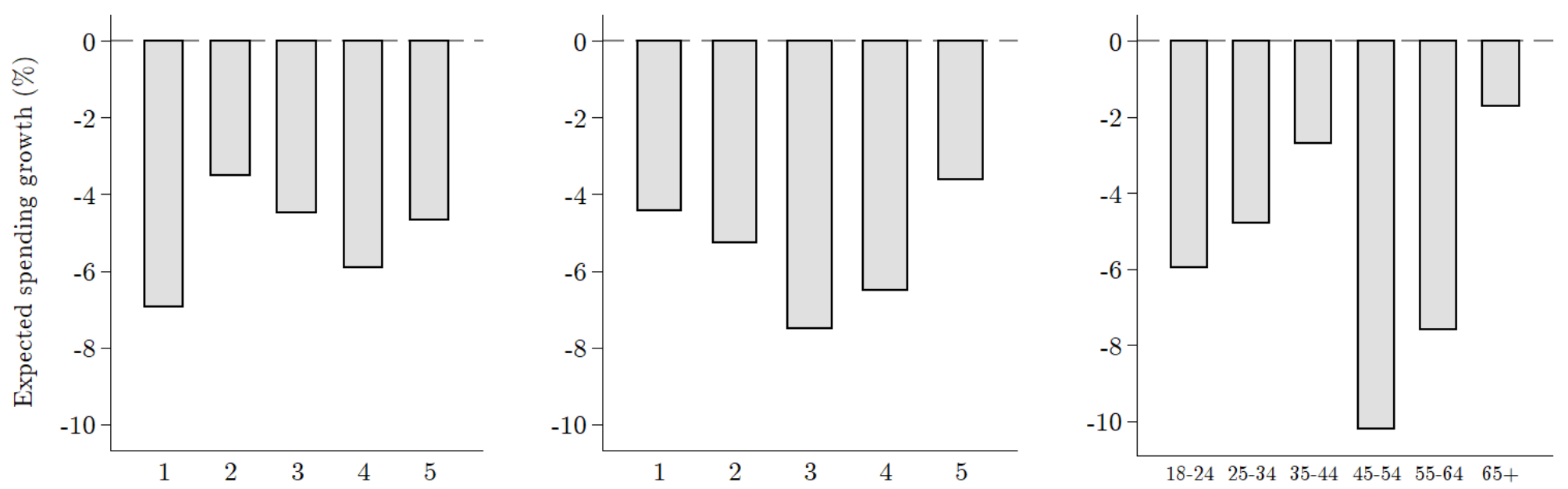

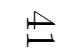
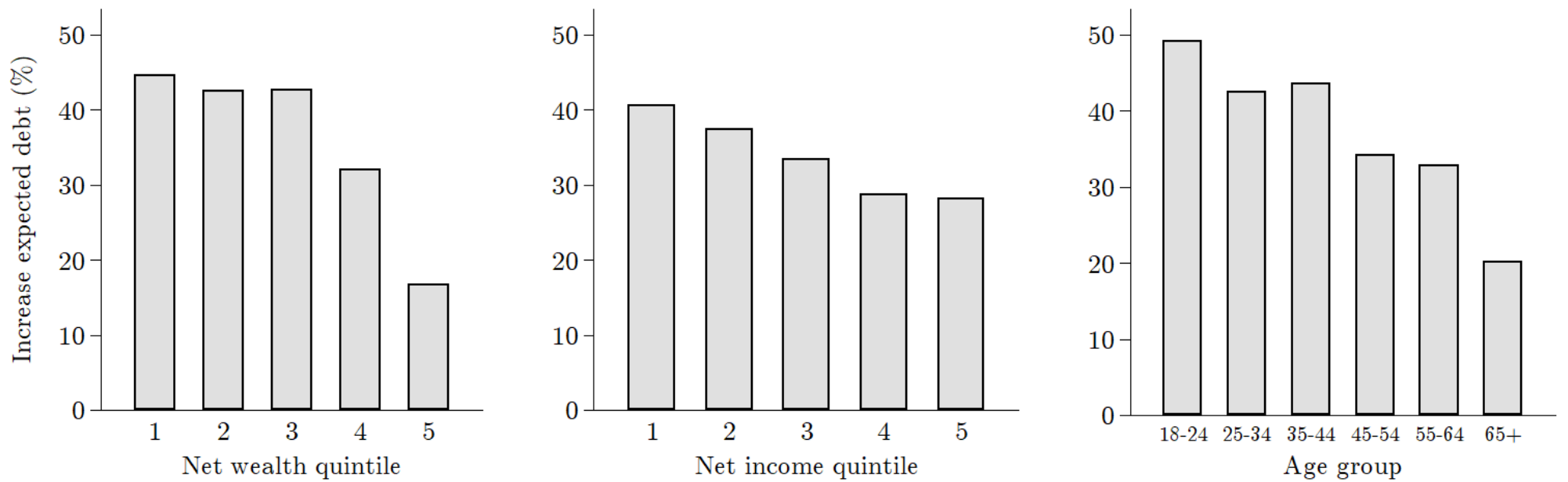

Notes: This figure displays the average percent change in expected total nominal household spending in 2020 compared to 2019 (top row) and the percent of respondents reporting that the current crisis increases their expected outstanding household debt by the end of the year 2020 (bottom row), by quintile of the pre-crisis net wealth distribution (left), by quintile of the pre-crisis net income distribution (middle) and by age group (right). The sample consists of respondents in the pure control group, who have not received any questions or information on past crashes before answering to the questions on spending and debt. 
Figure 4: Changes in expected labor market activity across groups
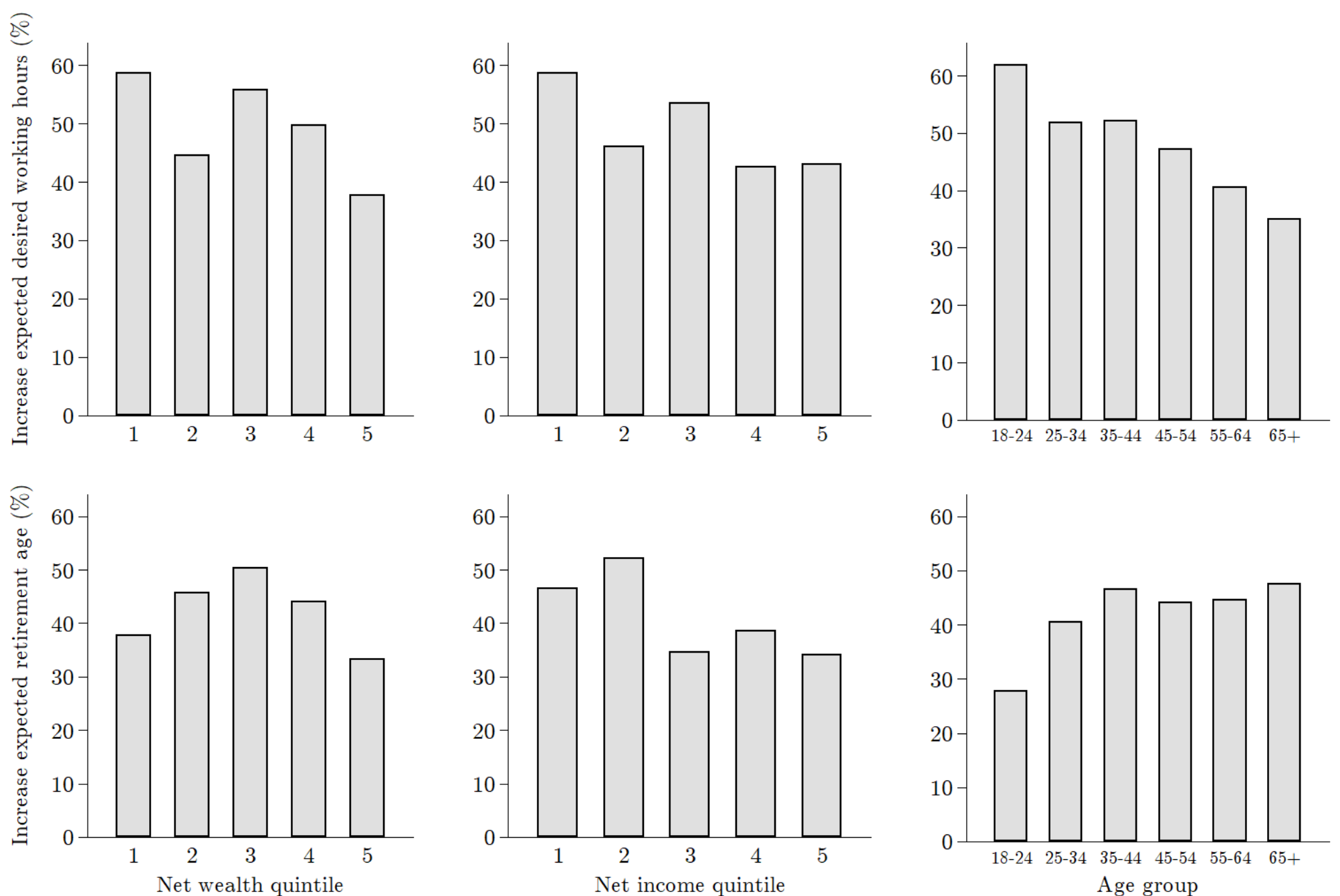

Notes: This figure displays the percent of respondents who report that they have upward adjusted their expectations about desired working hours in the next years (top row) or their retirement age (bottom row) due to the current crisis (bottom row), by quintile of the pre-crisis net wealth distribution (left), by quintile of the pre-crisis net income distribution (middle) and by age group (right). The sample consists of respondents in the pure control group, who have not received any questions or information on past crashes before answering to the questions on expected labor market activity. 
Figure 5: Beliefs about durations of current and historical stock market recoveries
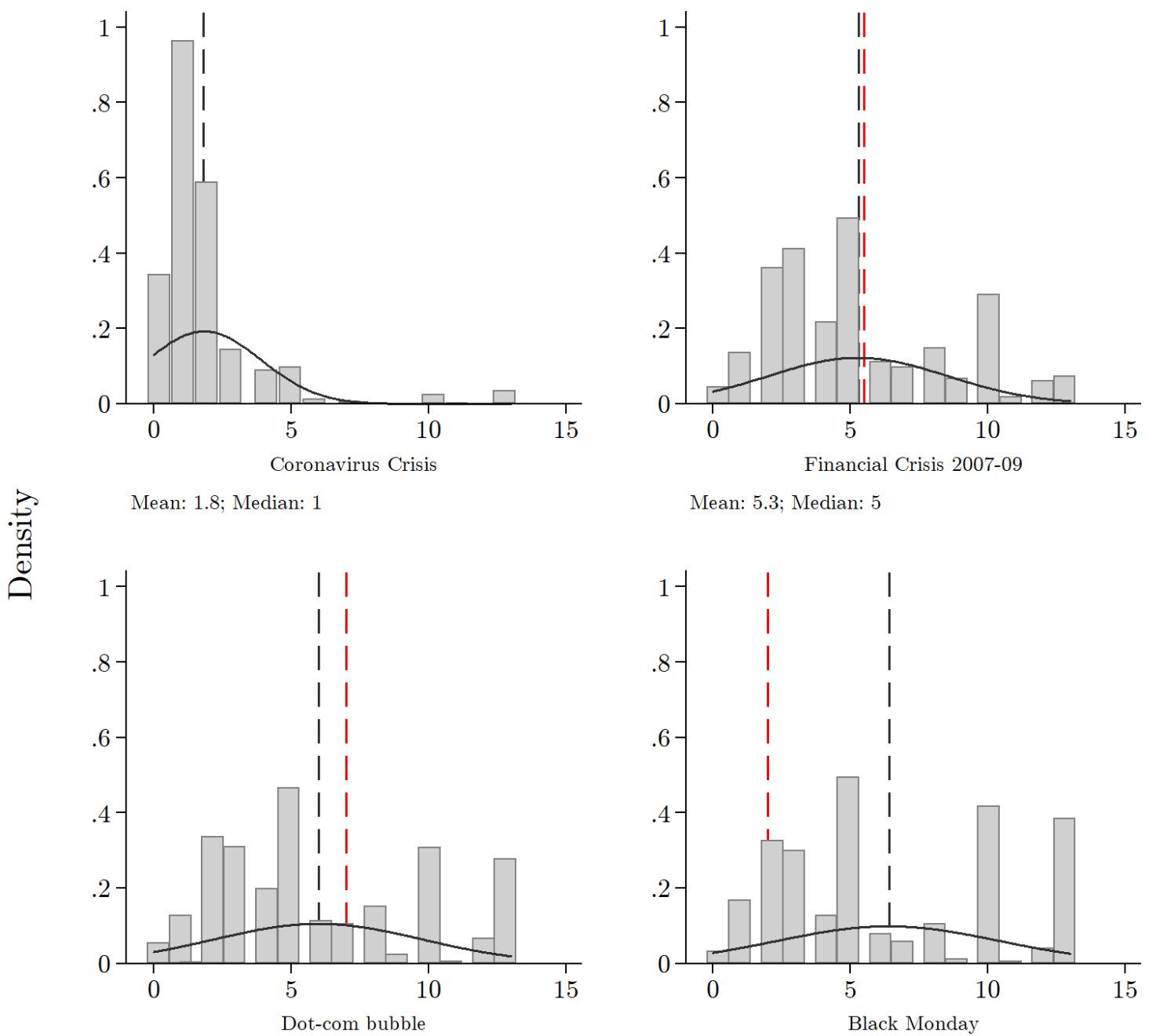

Mean: 6; Median: 5

Mean: 5.3; Median: 5

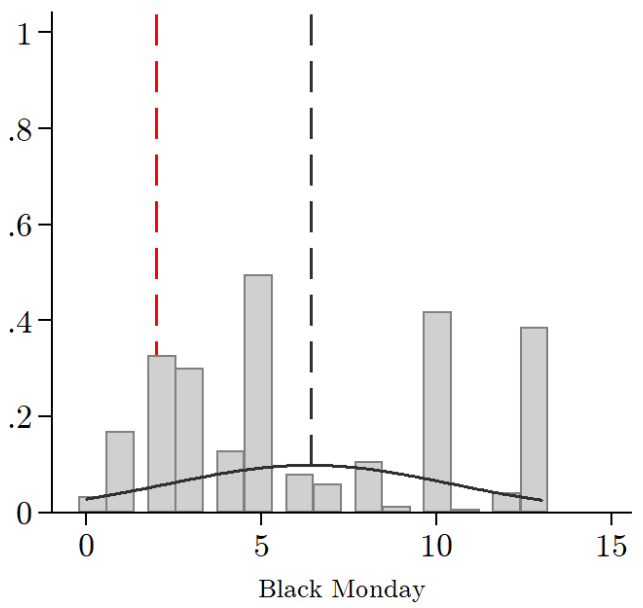

Mean: 6.4; Median: 5

\section{Years to recovery}

Notes: This figure displays respondents' subjective beliefs about the duration of the recovery of the US stock market in years for the Coronavirus crisis (top left), the Financial Crisis of 2007-2009 (top right), the Dot-com bubble (bottom left) and the crisis following Black Monday on October 19, 1987 (bottom right). The sample for the Coronavirus crisis consists of the pure control sample, where respondents did not receive any questions or information on past crashes before answering the question on expected recovery duration from the current crash. For the Financial Crisis, the Dot-com bubble and Black Monday it consists of the control and treatment samples in the relevant arms that answered questions on the corresponding crash. The expected duration is elicited prior to the respondent receiving information about the true duration (red dashed line). The mean estimate of the recovery duration is displayed as the black dashed line. Recovery duration is winsorized at 13 years in each subfigure. 


\section{Main tables}

Table 1: Descriptive statistics

\begin{tabular}{|c|c|c|c|c|c|c|c|c|}
\hline & \multicolumn{6}{|c|}{ Our sample } & \multicolumn{2}{|c|}{ ACS } \\
\hline & Mean & $\mathrm{SD}$ & $\mathrm{P} 10$ & Median & $\mathrm{P} 90$ & Obs. & Mean & Median \\
\hline Female & 0.51 & 0.50 & 0 & 1 & 1 & 7,447 & 0.51 & \\
\hline Age (years) & 48.64 & 16.29 & 26 & 49 & 70 & 7,447 & 47.60 & \\
\hline - $18-24$ years $(d)$ & 0.10 & 0.30 & 0 & 0 & 0 & 7,447 & 0.12 & \\
\hline - 25-34 years (d) & 0.16 & 0.36 & 0 & 0 & 1 & 7,447 & 0.18 & \\
\hline - 35-44 years $(d)$ & 0.19 & 0.39 & 0 & 0 & 1 & 7,447 & 0.16 & \\
\hline$-45-54$ years $(\mathrm{d})$ & 0.17 & 0.38 & 0 & 0 & 1 & 7,447 & 0.16 & \\
\hline - 55-65 years $(\mathrm{d})$ & 0.20 & 0.40 & 0 & 0 & 1 & 7,447 & 0.18 & \\
\hline - 65 years and older $(\mathrm{d})$ & 0.19 & 0.39 & 0 & 0 & 1 & 7,447 & 0.19 & \\
\hline Bachelor's degree or higher (d) & 0.39 & 0.49 & 0 & 0 & 1 & 7,447 & 0.30 & \\
\hline Some college $(\mathrm{d})$ & 0.40 & 0.49 & 0 & 0 & 1 & 7,447 & & \\
\hline High school (d) & 0.19 & 0.39 & 0 & 0 & 1 & 7,447 & & \\
\hline Married (d) & 0.53 & 0.50 & 0 & 1 & 1 & 7,447 & & \\
\hline Separated (d) & 0.13 & 0.34 & 0 & 0 & 1 & 7,447 & & \\
\hline Widowed (d) & 0.05 & 0.21 & 0 & 0 & 0 & 7,447 & & \\
\hline Household income (gross, USD) & 80,952 & 57,246 & 20,000 & 62,500 & 175,000 & 7,417 & 91,673 & 65,700 \\
\hline$-<15,000(\mathrm{~d})$ & 0.09 & 0.29 & 0 & 0 & 0 & 7,417 & 0.10 & \\
\hline$-15,000-25,000(\mathrm{~d})$ & 0.08 & 0.28 & 0 & 0 & 0 & 7,417 & 0.08 & \\
\hline - 25,000-50,000 (d) & 0.21 & 0.41 & 0 & 0 & 1 & 7,417 & 0.20 & \\
\hline - 50,000-75,000 (d) & 0.17 & 0.38 & 0 & 0 & 1 & 7,417 & 0.17 & \\
\hline$-75,000-100,000(d)$ & 0.14 & 0.35 & 0 & 0 & 1 & 7,417 & 0.13 & \\
\hline$-100,000-150,000(\mathrm{~d})$ & 0.17 & 0.38 & 0 & 0 & 1 & 7,417 & 0.16 & \\
\hline$-150,000-200,000(d)$ & 0.07 & 0.26 & 0 & 0 & 0 & 7,417 & 0.07 & \\
\hline$->200,000(\mathrm{~d})$ & 0.05 & 0.23 & 0 & 0 & 0 & 7,417 & 0.09 & \\
\hline \multicolumn{9}{|l|}{ Census Region (d) } \\
\hline - West & 0.22 & 0.41 & 0 & 0 & 1 & 7,447 & 0.24 & \\
\hline - Midwest & 0.25 & 0.43 & 0 & 0 & 1 & 7,447 & 0.21 & \\
\hline - Northeast & 0.21 & 0.41 & 0 & 0 & 1 & 7,447 & 0.18 & \\
\hline - South & 0.33 & 0.47 & 0 & 0 & 1 & 7,447 & 0.38 & \\
\hline Democrat & 0.39 & 0.49 & 0 & 0 & 1 & 7,447 & & \\
\hline Republican & 0.37 & 0.48 & 0 & 0 & 1 & 7,447 & & \\
\hline \multicolumn{9}{|l|}{ Employment situation (d) } \\
\hline - Employed & 0.53 & 0.50 & 0 & 1 & 1 & 7,447 & $0.62^{1)}$ & \\
\hline - Self-employed & 0.07 & 0.25 & 0 & 0 & 0 & 7,447 & & \\
\hline - Unemployed & 0.07 & 0.25 & 0 & 0 & 0 & 7,447 & 0.03 & \\
\hline - Out of labor force & 0.33 & 0.47 & 0 & 0 & 1 & 7,447 & 0.35 & \\
\hline Retired & 0.21 & 0.41 & 0 & 0 & 1 & 7,447 & & \\
\hline Other & 0.12 & 0.33 & 0 & 0 & 1 & 7,447 & & \\
\hline Financial wealth (USD) & 208,528 & 315,752 & 0 & 55,000 & 662,500 & 7,447 & & \\
\hline Retirement wealth (USD) & 120,738 & 180,658 & 0 & 17,500 & 575,000 & 7,447 & & \\
\hline Other financial wealth (USD) & 87,790 & 159,373 & 0 & 7,500 & 325,000 & 7,447 & & \\
\hline Real estate wealth (USD) & 223,761 & 338,990 & 0 & 150,000 & 625,000 & 7,447 & & \\
\hline Debt outstanding (USD) & 70,827 & 137,519 & 0 & 7,500 & 250,000 & 7,447 & & \\
\hline Household net wealth (USD) & 357,326 & 536,009 & $-11,500$ & 132,500 & $1,150,000$ & 7,447 & & \\
\hline Stock investor $(\mathrm{d})$ & 0.61 & 0.49 & 0 & 1 & 1 & 7,447 & & \\
\hline$\%$ Equity in fin. wealth (\%) & 39.14 & 33.23 & 0 & 40 & 91 & 5,835 & & \\
\hline Inv. experience $>10$ yrs. (d) & 0.55 & 0.50 & 0 & 1 & 1 & 4,567 & & \\
\hline Credit constrained (1-5) & 2.53 & 1.45 & 1 & 2 & 5 & 7,447 & & \\
\hline
\end{tabular}

Notes: The table shows summary statistics for the 7,447 respondents in the final sample. Stock market experience is elicited for stock investors only. The share of equity in total financial assets is conditional on positive financial asset holdings as of January 2020. Observation numbers for some wealth items vary due to item non-response. ${ }^{1)}$ includes self-employed. 
Table 2: Determinants of realized and planned adjustments to stock share

\begin{tabular}{|c|c|c|c|c|c|c|}
\hline & $\begin{array}{l}\text { Changed } \\
\text { stock } \\
\text { share }\end{array}$ & $\begin{array}{l}\text { Increased } \\
\text { stock } \\
\text { share }\end{array}$ & $\begin{array}{l}\text { Decreased } \\
\text { stock } \\
\text { share }\end{array}$ & $\begin{array}{c}\text { Plan change } \\
\text { stock } \\
\text { share }\end{array}$ & $\begin{array}{l}\text { Plan incr. } \\
\text { stock } \\
\text { share }\end{array}$ & $\begin{array}{c}\text { Plan decr. } \\
\text { stock } \\
\text { share }\end{array}$ \\
\hline & (1) & $(2)$ & $(3)$ & $(4)$ & $(5)$ & (6) \\
\hline$\Delta$ Net income $(\%)$ & $\begin{array}{l}-0.036 \\
(0.052)\end{array}$ & $\begin{array}{l}0.137^{* *} \\
(0.054)\end{array}$ & $\begin{array}{c}-0.173^{* * *} \\
(0.056)\end{array}$ & $\begin{array}{l}-0.062 \\
(0.055)\end{array}$ & $\begin{array}{c}0.100 \\
(0.062)\end{array}$ & $\begin{array}{c}-0.161^{* * *} \\
(0.058)\end{array}$ \\
\hline$\Delta$ Retirement fin. wealth $(\%)$ & & & & $\begin{array}{l}-0.090 \\
(0.088)\end{array}$ & $\begin{array}{l}-0.158^{*} \\
(0.084)\end{array}$ & $\begin{array}{c}0.068 \\
(0.073)\end{array}$ \\
\hline$\Delta$ Other fin. wealth $(\%)$ & & & & $\begin{array}{c}-0.269^{* * *} \\
(0.090)\end{array}$ & $\begin{array}{c}-0.214^{* *} \\
(0.088)\end{array}$ & $\begin{array}{l}-0.055 \\
(0.077)\end{array}$ \\
\hline Ln(Total fin. wealth) & $\begin{array}{c}2.836^{* * *} \\
(0.873)\end{array}$ & $\begin{array}{l}1.896^{* *} \\
(0.810)\end{array}$ & $\begin{array}{c}0.939 \\
(0.824)\end{array}$ & $\begin{array}{c}0.635 \\
(0.879)\end{array}$ & $\begin{array}{c}0.827 \\
(0.861)\end{array}$ & $\begin{array}{c}-0.191 \\
(0.822)\end{array}$ \\
\hline Stock share in ret. wealth & $\begin{array}{l}-0.049 \\
(0.034)\end{array}$ & $\begin{array}{c}0.000 \\
(0.029)\end{array}$ & $\begin{array}{l}-0.050^{*} \\
(0.028)\end{array}$ & $\begin{array}{c}-0.082^{* *} \\
(0.034)\end{array}$ & $\begin{array}{c}0.042 \\
(0.031)\end{array}$ & $\begin{array}{c}-0.124^{* * *} \\
(0.025)\end{array}$ \\
\hline Stock share in ot. fin wealth & $\begin{array}{c}0.010 \\
(0.033)\end{array}$ & $\begin{array}{c}0.020 \\
(0.028)\end{array}$ & $\begin{array}{l}-0.011 \\
(0.028)\end{array}$ & $\begin{array}{c}0.026 \\
(0.034)\end{array}$ & $\begin{array}{c}0.042 \\
(0.031)\end{array}$ & $\begin{array}{c}-0.016 \\
(0.026)\end{array}$ \\
\hline Share ret. in tot. fin. wealth & $\begin{array}{c}-0.151^{* * *} \\
(0.047)\end{array}$ & $\begin{array}{c}-0.103^{* *} \\
(0.042)\end{array}$ & $\begin{array}{l}-0.048 \\
(0.044)\end{array}$ & $\begin{array}{c}-0.173^{* * *} \\
(0.047)\end{array}$ & $\begin{array}{c}-0.177^{* * *} \\
(0.045)\end{array}$ & $\begin{array}{c}0.004 \\
(0.039)\end{array}$ \\
\hline Any loss fin. crisis & $\begin{array}{c}7.627^{* * *} \\
(2.538)\end{array}$ & $\begin{array}{c}3.634 \\
(2.493)\end{array}$ & $\begin{array}{c}3.993^{*} \\
(2.343)\end{array}$ & $\begin{array}{c}7.134^{* * *} \\
(2.525)\end{array}$ & $\begin{array}{l}-0.788 \\
(2.552)\end{array}$ & $\begin{array}{c}7.922^{* * *} \\
(2.222)\end{array}$ \\
\hline Big loss fin. crisis & $\begin{array}{c}1.199 \\
(3.152)\end{array}$ & $\begin{array}{c}-7.420^{* * *} \\
(2.681)\end{array}$ & $\begin{array}{c}8.619^{* * *} \\
(3.051)\end{array}$ & $\begin{array}{c}-6.637^{* *} \\
(3.011)\end{array}$ & $\begin{array}{c}-7.127^{* *} \\
(2.829)\end{array}$ & $\begin{array}{c}0.490 \\
(2.503)\end{array}$ \\
\hline Any loss dot-com & $\begin{array}{c}3.371 \\
(2.572)\end{array}$ & $\begin{array}{l}-1.338 \\
(2.359)\end{array}$ & $\begin{array}{l}4.709^{*} \\
(2.419)\end{array}$ & $\begin{array}{c}3.412 \\
(2.497)\end{array}$ & $\begin{array}{c}2.768 \\
(2.449)\end{array}$ & $\begin{array}{c}0.644 \\
(2.121)\end{array}$ \\
\hline Big loss dot-com & $\begin{array}{c}4.381 \\
(4.443)\end{array}$ & $\begin{array}{l}7.365^{*} \\
(4.023)\end{array}$ & $\begin{array}{l}-2.985 \\
(4.241)\end{array}$ & $\begin{array}{l}8.189^{*} \\
(4.445)\end{array}$ & $\begin{array}{l}7.820^{*} \\
(4.605)\end{array}$ & $\begin{array}{c}0.369 \\
(3.793)\end{array}$ \\
\hline Any loss Black Monday & $\begin{array}{l}8.085^{* *} \\
(3.312)\end{array}$ & $\begin{array}{c}0.340 \\
(2.576)\end{array}$ & $\begin{array}{l}7.745^{* * *} \\
(2.996)\end{array}$ & $\begin{array}{l}5.669^{*} \\
(3.112)\end{array}$ & $\begin{array}{c}2.839 \\
(2.752)\end{array}$ & $\begin{array}{c}2.829 \\
(2.349)\end{array}$ \\
\hline Big loss Black Monday & $\begin{array}{l}-2.557 \\
(6.099)\end{array}$ & $\begin{array}{c}2.844 \\
(4.796)\end{array}$ & $\begin{array}{l}-5.401 \\
(5.411)\end{array}$ & $\begin{array}{l}-0.854 \\
(6.063)\end{array}$ & $\begin{array}{l}-5.163 \\
(5.254)\end{array}$ & $\begin{array}{c}4.309 \\
(4.515)\end{array}$ \\
\hline Male & $\begin{array}{c}11.591^{* * *} \\
(2.350)\end{array}$ & $\begin{array}{c}7.224^{* * *} \\
(2.194)\end{array}$ & $\begin{array}{l}4.367^{* *} \\
(2.138)\end{array}$ & $\begin{array}{c}11.618^{* * *} \\
(2.418)\end{array}$ & $\begin{array}{c}9.003^{* * *} \\
(2.364)\end{array}$ & $\begin{array}{c}2.615 \\
(1.993)\end{array}$ \\
\hline At least bachelor & $\begin{array}{c}1.938 \\
(10.936)\end{array}$ & $\begin{array}{c}9.179 \\
(10.930)\end{array}$ & $\begin{array}{c}-7.240 \\
(11.352)\end{array}$ & $\begin{array}{c}-4.709 \\
(10.091)\end{array}$ & $\begin{array}{c}16.862 \\
(10.723)\end{array}$ & $\begin{array}{l}-21.572^{*} \\
(11.961)\end{array}$ \\
\hline Republican & $\begin{array}{l}-1.158 \\
(2.184)\end{array}$ & $\begin{array}{c}1.710 \\
(2.089)\end{array}$ & $\begin{array}{l}-2.868 \\
(2.058)\end{array}$ & $\begin{array}{c}3.080 \\
(2.182)\end{array}$ & $\begin{array}{l}3.661^{*} \\
(2.168)\end{array}$ & $\begin{array}{l}-0.581 \\
(1.923)\end{array}$ \\
\hline Individual controls & Yes & Yes & Yes & Yes & Yes & Yes \\
\hline Adj. R-squared & .213 & .148 & .045 & .27 & .132 & .119 \\
\hline Observations & 2,148 & 2,148 & 2,148 & 1,999 & 1,999 & 1,999 \\
\hline
\end{tabular}

Notes: This table shows OLS estimates of the determinants of realized and planned adjustments of the overall portfolio equity share. The outcomes are dummies indicating whether the respondent's household has made any change, has increased or has decreased the share of stocks and stock mutual funds in overall financial assets since the beginning of the stock market drop (columns 1-3) and dummies indicating plans to change, increase or decrease the equity share in overall financial assets in the weeks after the survey (columns 4-6), all coded as 0 or 100. All specifications are based on the four control arms, which have not received any information, using only respondents who report positive stockholdings as of January 2020. All specifications control for shocks to income, trimmed at the 2nd and 98th percentiles, dummies for having lost any wealth or substantial wealth during past stock market crashes, gender, age, employment status, being the main earner, being financial decision-maker, party affiliation, log net household income, log of total financial wealth, of real estate wealth, and of debt, share of total financial wealth in retirement accounts, borrowing constraints, stock market participation, stock shares in retirement and other accounts, investment experience, Census region, survey date, and the survey arm. Columns 4-6 additionally control for shocks to retirement and other financial wealth, trimmed at the 2 nd and 98 th percentile. Robust standard errors are reported in parentheses. $*$ denotes significance at the 10 pct., $* *$ at the 5 pct., and $* * *$ at the 1 pct. level. 
Table 3: Effects of wealth and income shocks on expected behavior and plans

\begin{tabular}{|c|c|c|c|c|c|c|}
\hline & $\begin{array}{c}\text { Exp. } \\
\text { spend. } \\
\text { growth }(\%) \\
\end{array}$ & $\begin{array}{c}\text { Exp. } \\
\text { spend. } \\
\text { growth }(\$)\end{array}$ & $\begin{array}{c}\text { Exp. } \\
\text { spend. } \\
\text { growth }(\$)\end{array}$ & $\begin{array}{l}\text { Incr. } \\
\text { exp. } \\
\text { debt }\end{array}$ & $\begin{array}{c}\text { Incr. exp. } \\
\text { desired } \\
\text { hours } \\
\end{array}$ & $\begin{array}{l}\text { Incr. exp. } \\
\text { retirement } \\
\text { age }\end{array}$ \\
\hline & (1) & $(2)$ & $(3)$ & (4) & $(5)$ & (6) \\
\hline$\Delta$ Retirement fin. wealth $(\%)$ & $\begin{array}{c}0.054 \\
(0.036)\end{array}$ & & & $\begin{array}{c}-0.206^{* * *} \\
(0.073)\end{array}$ & $\begin{array}{c}-0.302^{* * *} \\
(0.089)\end{array}$ & $\begin{array}{c}-0.398^{* * *} \\
(0.096)\end{array}$ \\
\hline$\Delta$ Other fin. wealth $(\%)$ & $\begin{array}{l}-0.044 \\
(0.037)\end{array}$ & & & $\begin{array}{c}-0.432^{* * *} \\
(0.073)\end{array}$ & $\begin{array}{c}-0.401^{* * *} \\
(0.090)\end{array}$ & $\begin{array}{c}-0.257^{* * *} \\
(0.094)\end{array}$ \\
\hline$\Delta$ Net income (quarterly, \%) & $\begin{array}{c}0.171^{* * *} \\
(0.027)\end{array}$ & & & $\begin{array}{c}-0.320^{* * *} \\
(0.042)\end{array}$ & $\begin{array}{c}-0.328^{* * *} \\
(0.049)\end{array}$ & $\begin{array}{c}-0.221^{* * *} \\
(0.054)\end{array}$ \\
\hline$\Delta$ Retirement fin. wealth $(\$)$ & & $\begin{array}{c}0.024^{\text {*** }} \\
(0.009)\end{array}$ & $\begin{array}{c}0.021^{* *} \\
(0.009)\end{array}$ & & & \\
\hline$\Delta$ Other fin. wealth $(\$)$ & & $\begin{array}{c}-0.001 \\
(0.012)\end{array}$ & $\begin{array}{c}-0.004 \\
(0.012)\end{array}$ & & & \\
\hline$\Delta$ Net income (quarterly, $\$$ ) & & $\begin{array}{c}0.655^{* * *} \\
(0.104)\end{array}$ & & & & \\
\hline$\Delta$ Net income (annual, $\$$ ) & & & $\begin{array}{c}0.454^{* * *} \\
(0.071)\end{array}$ & & & \\
\hline Individual controls & Yes & Yes & Yes & Yes & Yes & Yes \\
\hline Adj. R-squared & .041 & .053 & .084 & .215 & .146 & .095 \\
\hline Observations & 3,761 & 3,565 & 3,535 & 3,845 & 2,377 & 2,377 \\
\hline
\end{tabular}

Notes: This table shows estimates of the association of shocks to the respondent's household financial wealth and net income with expected economic decisions. The outcomes are expected growth of yearly household spending from 2019 to 2020 in percent, trimmed at the 2nd and 98th percentiles (column 1); expected household spending growth in dollars, trimmed at the 2nd and 98th percentiles (columns 2-3); and dummies indicating whether the coronavirus crisis increases the respondent's expectations about outstanding household debt by the end of 2020 (column 4), expected desired working hours over the next years (column 5, only if in labor force) or expected retirement age (column 6, only if in labor force), all coded as 0 or 100. Dollar changes in columns 2 and 3 are constructed from survey questions for retirement and other financial wealth and for income (assuming that the respondent expected a quarter of her 2019 income in the first quarter of 2020), and for spending from the survey question on percent changes and estimates of the level of spending of different groups in 2019 from the CEX. Columns 1, 2, 4, 5 and 6 show simple OLS estimates. Column 3 shows 2SLS estimates, where the respondent's expected dollar change in household income from 2019 to 2020 is instrumented with the unexpected shock to household income over the first quarter of 2020. All specifications are based on the four control arms, which have not received any information. All specifications control for gender, age, employment status, being the main earner, being financial decision-maker, party affiliation, log net household income, logs of retirement wealth, of other financial wealth, of real estate wealth, and of debt, borrowing constraints, stock market participation, the equity share in total financial assets, investment experience, Census region, survey date, and the survey arm. Robust standard errors are reported in parentheses. ${ }^{*}$ denotes significance at the 10 pct., ${ }^{* *}$ at the 5 pct., and $* * *$ at the 1 pct. level. 
Table 4: Determinants of expectations about the stock market and own wealth

\begin{tabular}{|c|c|c|c|c|c|c|c|c|}
\hline & $\begin{array}{c}\begin{array}{c}\text { Stock } \\
\text { recovery } \\
\text { duration }\end{array} \\
\end{array}$ & $\begin{array}{c}\text { Stock } \\
\text { return: } \\
\text { Mean } \\
\end{array}$ & $\begin{array}{l}\text { Stock } \\
\text { return: } \\
\text { SD } \\
\end{array}$ & $\begin{array}{l}\text { Stock } \\
\text { return } \\
<-30 \% \\
\end{array}$ & $\begin{array}{l}\text { Stock } \\
\text { return } \\
>30 \% \\
\end{array}$ & $\begin{array}{l}\text { Wealth } \\
\text { recovery } \\
\text { duration } \\
\end{array}$ & $\begin{array}{l}\text { Exp. wealth } \\
\text { never to } \\
\text { recover } \\
\end{array}$ & $\begin{array}{c}\text { Household } \\
\text { financial } \\
\text { prospects } \\
\end{array}$ \\
\hline & $(1)$ & $(2)$ & $(3)$ & $(4)$ & $(5)$ & $(6)$ & (7) & $(8)$ \\
\hline$\Delta$ Fin. wealth $(\%)$ & $\begin{array}{l}-0.005 \\
(0.004)\end{array}$ & $\begin{array}{c}-0.012 \\
(0.026)\end{array}$ & $\begin{array}{c}-0.045^{* * *} \\
(0.013)\end{array}$ & $\begin{array}{l}-0.014 \\
(0.030)\end{array}$ & $\begin{array}{c}-0.077^{*} \\
(0.039)\end{array}$ & $\begin{array}{c}-0.034^{* * *} \\
(0.003)\end{array}$ & $\begin{array}{c}-0.159^{* * *} \\
(0.054)\end{array}$ & $\begin{array}{c}0.005^{* * *} \\
(0.002)\end{array}$ \\
\hline$\Delta$ Net income $(\%)$ & $\begin{array}{c}-0.010^{* * *} \\
(0.003)\end{array}$ & $\begin{array}{c}0.085^{* * *} \\
(0.017)\end{array}$ & $\begin{array}{l}-0.001 \\
(0.009)\end{array}$ & $\begin{array}{c}-0.100^{* * *} \\
(0.023)\end{array}$ & $\begin{array}{c}0.067^{* * *} \\
(0.022)\end{array}$ & $\begin{array}{c}-0.005^{* * *} \\
(0.002)\end{array}$ & $\begin{array}{c}-0.088^{* *} \\
(0.038)\end{array}$ & $\begin{array}{c}0.007^{* * *} \\
(0.001)\end{array}$ \\
\hline Any loss fin. crisis & $\begin{array}{l}-0.007 \\
(0.120)\end{array}$ & $\begin{array}{c}-1.679^{* *} \\
(0.804)\end{array}$ & $\begin{array}{c}0.602 \\
(0.414)\end{array}$ & $\begin{array}{c}1.289 \\
(1.006)\end{array}$ & $\begin{array}{l}-1.504 \\
(1.162)\end{array}$ & $\begin{array}{c}0.237^{* * *} \\
(0.084)\end{array}$ & $\begin{array}{c}4.460^{* * *} \\
(1.691)\end{array}$ & $\begin{array}{c}-0.077^{*} \\
(0.046)\end{array}$ \\
\hline Big loss fin. crisis & $\begin{array}{l}0.302^{* *} \\
(0.150)\end{array}$ & $\begin{array}{l}-1.965^{*} \\
(1.128)\end{array}$ & $\begin{array}{l}-0.542 \\
(0.515)\end{array}$ & $\begin{array}{c}2.302 \\
(1.451)\end{array}$ & $\begin{array}{l}-0.404 \\
(1.593)\end{array}$ & $\begin{array}{c}0.156 \\
(0.128)\end{array}$ & $\begin{array}{l}-0.540 \\
(2.166)\end{array}$ & $\begin{array}{c}-0.260^{* * *} \\
(0.062)\end{array}$ \\
\hline Any loss dot-com & $\begin{array}{c}-0.069 \\
(0.125)\end{array}$ & $\begin{array}{l}-0.362 \\
(0.861)\end{array}$ & $\begin{array}{l}1.088^{* *} \\
(0.428)\end{array}$ & $\begin{array}{c}0.261 \\
(1.117)\end{array}$ & $\begin{array}{c}-1.162 \\
(1.206)\end{array}$ & $\begin{array}{c}0.012 \\
(0.106)\end{array}$ & $\begin{array}{c}0.223 \\
(1.745)\end{array}$ & $\begin{array}{l}-0.009 \\
(0.049)\end{array}$ \\
\hline Big loss dot-com & $\begin{array}{l}-0.215 \\
(0.219)\end{array}$ & $\begin{array}{l}-1.588 \\
(1.662)\end{array}$ & $\begin{array}{l}-0.860 \\
(0.705)\end{array}$ & $\begin{array}{l}4.313^{*} \\
(2.359)\end{array}$ & $\begin{array}{c}0.608 \\
(2.182)\end{array}$ & $\begin{array}{l}-0.258^{*} \\
(0.155)\end{array}$ & $\begin{array}{c}3.862 \\
(3.267)\end{array}$ & $\begin{array}{l}-0.040 \\
(0.098)\end{array}$ \\
\hline Any loss Black Monday & $\begin{array}{l}0.282^{*} \\
(0.154)\end{array}$ & $\begin{array}{l}-1.478 \\
(1.046)\end{array}$ & $\begin{array}{l}-0.700 \\
(0.520)\end{array}$ & $\begin{array}{l}-0.900 \\
(1.354)\end{array}$ & $\begin{array}{c}-3.558^{* *} \\
(1.530)\end{array}$ & $\begin{array}{l}0.239^{*} \\
(0.122)\end{array}$ & $\begin{array}{l}-0.998 \\
(2.049)\end{array}$ & $\begin{array}{l}-0.057 \\
(0.054)\end{array}$ \\
\hline Big loss Black Monday & $\begin{array}{c}0.206 \\
(0.289)\end{array}$ & $\begin{array}{c}0.649 \\
(1.976)\end{array}$ & $\begin{array}{l}-0.596 \\
(0.813)\end{array}$ & $\begin{array}{c}0.403 \\
(2.798)\end{array}$ & $\begin{array}{c}1.511 \\
(2.551)\end{array}$ & $\begin{array}{c}0.280 \\
(0.248)\end{array}$ & $\begin{array}{c}5.851 \\
(4.212)\end{array}$ & $\begin{array}{l}-0.042 \\
(0.104)\end{array}$ \\
\hline Male & $\begin{array}{c}-0.640^{* * *} \\
(0.103)\end{array}$ & $\begin{array}{c}0.218 \\
(0.709)\end{array}$ & $\begin{array}{l}0.693^{* *} \\
(0.345)\end{array}$ & $\begin{array}{l}-1.167 \\
(0.913)\end{array}$ & $\begin{array}{c}0.082 \\
(1.047)\end{array}$ & $\begin{array}{c}-0.184^{* * *} \\
(0.059)\end{array}$ & $\begin{array}{l}-1.000 \\
(1.404)\end{array}$ & $\begin{array}{c}0.186^{* * *} \\
(0.037)\end{array}$ \\
\hline At least bachelor & $\begin{array}{l}-0.069 \\
(0.317)\end{array}$ & $\begin{array}{c}0.279 \\
(2.083)\end{array}$ & $\begin{array}{l}-1.090 \\
(1.003)\end{array}$ & $\begin{array}{c}-5.728^{*} \\
(3.022)\end{array}$ & $\begin{array}{l}-1.814 \\
(2.820)\end{array}$ & $\begin{array}{c}-0.303^{* *} \\
(0.145)\end{array}$ & $\begin{array}{c}-10.735^{* *} \\
(4.637)\end{array}$ & $\begin{array}{c}0.093 \\
(0.104)\end{array}$ \\
\hline Republican & $\begin{array}{c}-0.657^{* * *} \\
(0.095)\end{array}$ & $\begin{array}{c}5.844^{* * *} \\
(0.680)\end{array}$ & $\begin{array}{c}-0.808^{* *} \\
(0.337)\end{array}$ & $\begin{array}{c}-3.577^{* * *} \\
(0.862)\end{array}$ & $\begin{array}{c}7.224^{* * *} \\
(1.010)\end{array}$ & $\begin{array}{c}-0.222^{* * *} \\
(0.064)\end{array}$ & $\begin{array}{c}-4.639^{* * *} \\
(1.361)\end{array}$ & $\begin{array}{c}0.240^{* * *} \\
(0.036)\end{array}$ \\
\hline Stock investor & $\begin{array}{c}-0.445^{* *} \\
(0.194)\end{array}$ & $\begin{array}{c}0.088 \\
(1.309)\end{array}$ & $\begin{array}{l}1.314^{*} \\
(0.682)\end{array}$ & $\begin{array}{l}-0.400 \\
(1.676)\end{array}$ & $\begin{array}{c}-0.482 \\
(1.865)\end{array}$ & $\begin{array}{c}0.469^{* * *} \\
(0.125)\end{array}$ & $\begin{array}{c}2.493 \\
(2.754)\end{array}$ & $\begin{array}{l}0.137^{*} \\
(0.072)\end{array}$ \\
\hline Individual controls & Yes & Yes & Yes & Yes & Yes & Yes & Yes & Yes \\
\hline Adj. R-squared & .092 & .048 & .054 & .024 & .037 & .304 & .081 & .088 \\
\hline Observations & 3,918 & 3,918 & 3,918 & 3,918 & 3,918 & 3,614 & 3,918 & 3,918 \\
\hline
\end{tabular}

Notes: This table shows OLS estimates of the determinants of respondents' expectations about the stock market and their own wealth. The outcomes are the expected duration of the recovery of the US stock market to its pre-crisis level of January 2020 in years (column 1); mean and standard deviation as well as probabilities assigned to extreme return realizations based on the respondent's reported probability distribution over the one year-ahead stock market return (columns 2-5); the expected recovery duration of the respondent's household net wealth (column 6); a dummy indicating whether the respondent thinks her household net wealth will never recover, coded as 0 or 100 (column 7); and a categorical measure of the respondent's subjective household financial prospects, z-scored using the mean and standard deviation in the sample (column 8). All specifications are based on the four control arms, which have not received any information. All specifications control for shocks to income and financial wealth, trimmed at the 2nd and 98th percentiles, dummies for having lost any wealth or substantial wealth during past stock market crashes, gender, age, employment status, being the main earner, being financial decision-maker, party affiliation, log net household income, logs of retirement wealth, of other financial wealth, of real estate wealth, and of debt, borrowing constraints, stock market participation, the equity share in total financial assets, investment experience, Census region, survey date, and the survey arm. Robust standard errors are reported in parentheses. ${ }^{*}$ denotes significance at the 10 pct., ${ }^{* *}$ at the 5 pct., and ${ }^{* * *}$ at the 1 pct. level. 
Table 5: Effects of information on stock market expectations: Experimental first stage

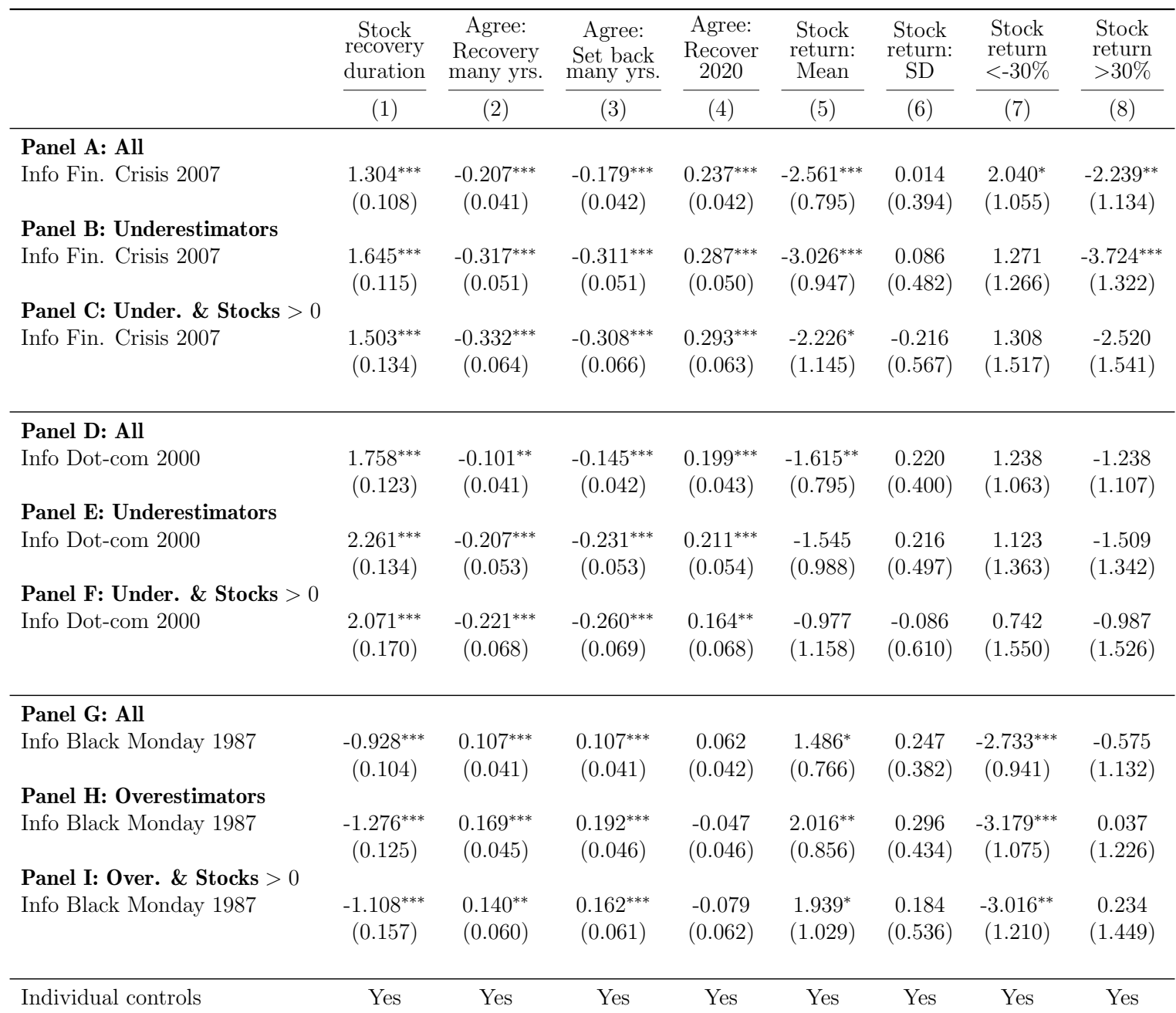

Notes: This table shows OLS estimates of the effect of being shown information on the duration of a historical stock market crash on respondent's expectations about the stock market. The outcomes are the expected duration of the recovery of the US stock market to its pre-crisis level of January 2020 in years (column 1); agreement on 7-point scales to statements describing the severity of the current stock market crash, z-scored using the mean and the standard deviation in the sample (columns 2-4); mean and standard deviation as well as probabilities assigned to extreme return realizations based on the respondent's reported probability distribution over the one year-ahead stock market return (columns 5-8). Panels A-C are based on the treatment and control arms including information or questions on the Financial Crisis 2007. Panels D-F are based on the treatment and control arms including information or questions on the burst of the Dot-com bubble 2000. Panels G-I are based on the treatment and control arms including information or questions on the Black Monday 1987. Panels A, D and G are based on the full sample in the corresponding arms. Panels B, E and $\mathrm{H}$ are based only on under-estimators (for Financial Crisis and Dot-com bubble) or over-estimators (for Black Monday) of the length of the recovery from the crash. Panels C, F and I are based only on under-estimators or over-estimators who participated in the stock market before the current crisis. All specifications control for the respondent's prior belief about the recovery duration following the corresponding crash as well as for gender, age, employment status, being the main earner, being financial decision-maker, party affiliation, log net household income, logs of retirement wealth, of other financial wealth, of real estate wealth, and of debt, borrowing constraints, stock market participation, the equity share in total financial assets, investment experience, Census region and survey date. Robust standard errors are reported in parentheses. ${ }^{*}$ denotes significance at the 10 pct., ${ }^{* *}$ at the 5 pct., and ${ }^{* * *}$ at the 1 pct. level. 
Table 6: Effects of expected stock market recovery on own outlook and plans: OLS and 2SLS estimates

\begin{tabular}{|c|c|c|c|c|c|c|c|c|}
\hline & $\begin{array}{l}\text { Wealth } \\
\text { recovery } \\
\text { duration }\end{array}$ & $\begin{array}{l}\text { Household } \\
\text { financial } \\
\text { prospects }\end{array}$ & $\begin{array}{l}\text { Plan incr. } \\
\text { stock } \\
\text { share }\end{array}$ & $\begin{array}{l}\text { Plan decr. } \\
\text { stock } \\
\text { share }\end{array}$ & $\begin{array}{l}\text { Exp. } \\
\text { spend. } \\
\text { growth }\end{array}$ & $\begin{array}{l}\text { Incr. } \\
\text { exp. } \\
\text { debt }\end{array}$ & $\begin{array}{c}\text { Incr. exp. } \\
\text { desired } \\
\text { hours }\end{array}$ & $\begin{array}{l}\text { Incr. exp. } \\
\text { retirement } \\
\text { age }\end{array}$ \\
\hline & (1) & $(2)$ & $(3)$ & $(4)$ & $(5)$ & (6) & $(7)$ & (8) \\
\hline \multicolumn{9}{|l|}{ Panel A: All control groups (OLS) } \\
\hline Expected stock recovery duration (years) & $\begin{array}{c}0.223^{* * *} \\
(0.017)\end{array}$ & $\begin{array}{c}-0.070^{* * *} \\
(0.006)\end{array}$ & $\begin{array}{c}-0.584^{* *} \\
(0.282)\end{array}$ & $\begin{array}{c}0.530^{*} \\
(0.280)\end{array}$ & $\begin{array}{l}-0.250^{*} \\
(0.138)\end{array}$ & $\begin{array}{c}1.063^{* * *} \\
(0.258)\end{array}$ & $\begin{array}{c}1.303^{* * *} \\
(0.356)\end{array}$ & $\begin{array}{c}1.727^{* * *} \\
(0.362)\end{array}$ \\
\hline Observations & 3,903 & 4,260 & 2,599 & 2,599 & 4,097 & 4,260 & 2,682 & 2,682 \\
\hline \multicolumn{9}{|l|}{ Panel B: All control groups\&Stocks (OLS) } \\
\hline Expected stock recovery duration (years) & $\begin{array}{c}0.455^{* * *} \\
(0.029)\end{array}$ & $\begin{array}{c}-0.088^{* * *} \\
(0.009)\end{array}$ & $\begin{array}{c}-0.584^{* *} \\
(0.282)\end{array}$ & $\begin{array}{c}0.530^{*} \\
(0.280)\end{array}$ & $\begin{array}{c}-0.546^{* * *} \\
(0.178)\end{array}$ & $\begin{array}{c}0.517 \\
(0.342)\end{array}$ & $\begin{array}{c}2.050^{* * *} \\
(0.453)\end{array}$ & $\begin{array}{c}2.065^{* * *} \\
(0.464)\end{array}$ \\
\hline Observations & 2,297 & 2,599 & 2,599 & 2,599 & 2,515 & 2,599 & 1,915 & 1,915 \\
\hline \multicolumn{9}{|l|}{ Panel C: Fin. Cris. Und.\&Stocks (OLS) } \\
\hline Expected stock recovery duration (years) & $\begin{array}{c}0.407^{* * *} \\
(0.043)\end{array}$ & $\begin{array}{c}-0.113^{* * *} \\
(0.017)\end{array}$ & $\begin{array}{l}-0.300 \\
(0.556)\end{array}$ & $\begin{array}{c}0.517 \\
(0.625)\end{array}$ & $\begin{array}{c}-0.693^{*} \\
(0.372)\end{array}$ & $\begin{array}{c}2.102^{* * *} \\
(0.714)\end{array}$ & $\begin{array}{c}3.079^{* * *} \\
(0.894)\end{array}$ & $\begin{array}{c}4.184^{* * *} \\
(0.789)\end{array}$ \\
\hline \multicolumn{9}{|l|}{ Panel D: Fin. Cris. Und.\&Stocks (2SLS) } \\
\hline Expected stock recovery duration (years) & $\begin{array}{c}0.487^{* * *} \\
(0.072)\end{array}$ & $\begin{array}{c}-0.091^{* *} \\
(0.042)\end{array}$ & $\begin{array}{c}1.844 \\
(1.491)\end{array}$ & $\begin{array}{c}2.096 \\
(1.413)\end{array}$ & $\begin{array}{l}-0.844 \\
(0.852)\end{array}$ & $\begin{array}{c}2.063 \\
(1.936)\end{array}$ & $\begin{array}{l}5.770^{* *} \\
(2.321)\end{array}$ & $\begin{array}{l}5.704^{* *} \\
(2.377)\end{array}$ \\
\hline First-stage F-stat & 130.984 & 125.897 & 131.394 & 131.394 & 129.047 & 125.897 & 108.424 & 108.424 \\
\hline Observations & 781 & 879 & 879 & 879 & 854 & 879 & 675 & 675 \\
\hline \multicolumn{9}{|l|}{ Panel E: Dot-com Und.\&Stocks (OLS) } \\
\hline Expected stock recovery duration (years) & $\begin{array}{c}0.429^{* * *} \\
(0.046)\end{array}$ & $\begin{array}{c}-0.073^{* * *} \\
(0.014)\end{array}$ & $\begin{array}{l}-0.190 \\
(0.537)\end{array}$ & $\begin{array}{c}0.337 \\
(0.477)\end{array}$ & $\begin{array}{c}-0.402 \\
(0.309)\end{array}$ & $\begin{array}{c}0.426 \\
(0.552)\end{array}$ & $\begin{array}{c}0.870 \\
(0.707)\end{array}$ & $\begin{array}{c}0.958 \\
(0.715)\end{array}$ \\
\hline \multicolumn{9}{|l|}{ Panel F: Dot-com Und.\&Stocks (2SLS) } \\
\hline Expected stock recovery duration (years) & $\begin{array}{c}0.519^{* * *} \\
(0.073)\end{array}$ & $\begin{array}{c}0.025 \\
(0.033)\end{array}$ & $\begin{array}{c}0.553 \\
(1.215)\end{array}$ & $\begin{array}{l}-1.428 \\
(1.075)\end{array}$ & $\begin{array}{c}0.371 \\
(0.639)\end{array}$ & $\begin{array}{c}0.081 \\
(1.362)\end{array}$ & $\begin{array}{c}-0.639 \\
(1.779)\end{array}$ & $\begin{array}{l}-1.924 \\
(1.867)\end{array}$ \\
\hline First-stage F-stat & 119.547 & 148.127 & 150.857 & 150.857 & 150.266 & 148.127 & 112.237 & 112.237 \\
\hline Observations & 740 & 839 & 839 & 839 & 823 & 839 & 625 & 625 \\
\hline \multicolumn{9}{|l|}{ Panel G: Black Mon. Over.\&Stocks (OLS) } \\
\hline Expected stock recovery duration (years) & $\begin{array}{c}0.531^{* * *} \\
(0.040)\end{array}$ & $\begin{array}{c}-0.081^{* * *} \\
(0.012)\end{array}$ & $\begin{array}{c}-1.680^{* * *} \\
(0.415)\end{array}$ & $\begin{array}{c}1.192^{* * *} \\
(0.409)\end{array}$ & $\begin{array}{c}-1.196^{* * *} \\
(0.266)\end{array}$ & $\begin{array}{c}0.635 \\
(0.534)\end{array}$ & $\begin{array}{c}1.124 \\
(0.727)\end{array}$ & $\begin{array}{c}0.837 \\
(0.718)\end{array}$ \\
\hline \multicolumn{9}{|l|}{ Panel H: Black Mon. Over.\&Stocks (2SLS) } \\
\hline Expected stock recovery duration (years) & $\begin{array}{c}0.341^{* * *} \\
(0.102)\end{array}$ & $\begin{array}{l}-0.087 \\
(0.054)\end{array}$ & $\begin{array}{c}-4.298^{* *} \\
(2.058)\end{array}$ & $\begin{array}{l}3.773^{* *} \\
(1.820)\end{array}$ & $\begin{array}{l}-1.118 \\
(1.136)\end{array}$ & $\begin{array}{l}4.532^{*} \\
(2.453)\end{array}$ & $\begin{array}{c}1.220 \\
(3.600)\end{array}$ & $\begin{array}{c}3.828 \\
(3.716)\end{array}$ \\
\hline First-stage F-stat & 48.703 & 50.007 & 48.322 & 48.322 & 54.393 & 50.007 & 27.102 & 27.102 \\
\hline Observations & 903 & 1,033 & 1,033 & 1,033 & 993 & 1,033 & 756 & 756 \\
\hline Individual controls & Yes & Yes & Yes & Yes & Yes & Yes & Yes & Yes \\
\hline
\end{tabular}

Notes: This table shows OLS and 2SLS estimates of the effect of respondents' expected stock market recovery duration on their expectations about their own financial situation and behavior. The outcomes are the expected recovery duration of the respondent's household net wealth (column 1); a categorical measure of the respondent's subjective household financial prospects, z-scored using the mean and standard deviation in the sample (column 2); dummies indicating plans to increase or decrease the equity share in overall financial assets in the weeks after the survey (columns 3-4, only for stockholders); expected growth of yearly household spending from 2019 to 2020 in percent, trimmed at the 2 nd and 98 th percentiles (column 5); dummies indicating whether the coronavirus crisis increases the respondent's expectations about outstanding household debt by the end of 2020 (column 6), expected desired working hours over the next years (column 7, only if in labor force) or expected retirement age (column 8 , only if in labor force). All dummy outcomes are coded as 0 or 100. Panels A and B are based on the four control arms, which have not received any information. In Panels D, F and $\mathrm{H}$, we use the relevant information treatment dummy as instrument for expected recovery duration. Panels C-D are based on the treatment and control arms including information or questions on the Financial Crisis 2007, Panels E-F are based on the Dot-com arms, and Panels G-H are based on the Black Monday arms. Panels C-F are restricted to under-estimators and Panels G-H to over-estimators. Panels B-H are restricted to those who participated in the stock market before the current crisis. All specifications control for gender, age, employment status, being the main earner, being financial decision-maker, party affiliation, log net household income, logs of retirement wealth, of other financial wealth, of real estate wealth, and of debt, borrowing constraints, stock market participation, the equity share in total financial assets, investment experience, Census region and survey date. The specifications on planned stock trading in columns 3 and 4 also control for realized trading since the onset of the crisis. Panels C-H also control for the respondent's prior belief about the recovery duration following the corresponding crash. Robust standard errors are reported in parentheses. * denotes significance at the 10 pct., ** at the 5 pct., and *** at the 1 pct. level. 


\title{
Online Appendix: Exposure to the COVID-19 Stock Market

\author{
Crash and its Effect on Household Expectations
}

\author{
Tobin Hanspal $^{1} \quad$ Annika Weber ${ }^{2} \quad$ Johannes Wohlfart $^{3}$
}

\section{A Additional figures}

Figure A1: US stock market and number of initial jobless claims around the survey period

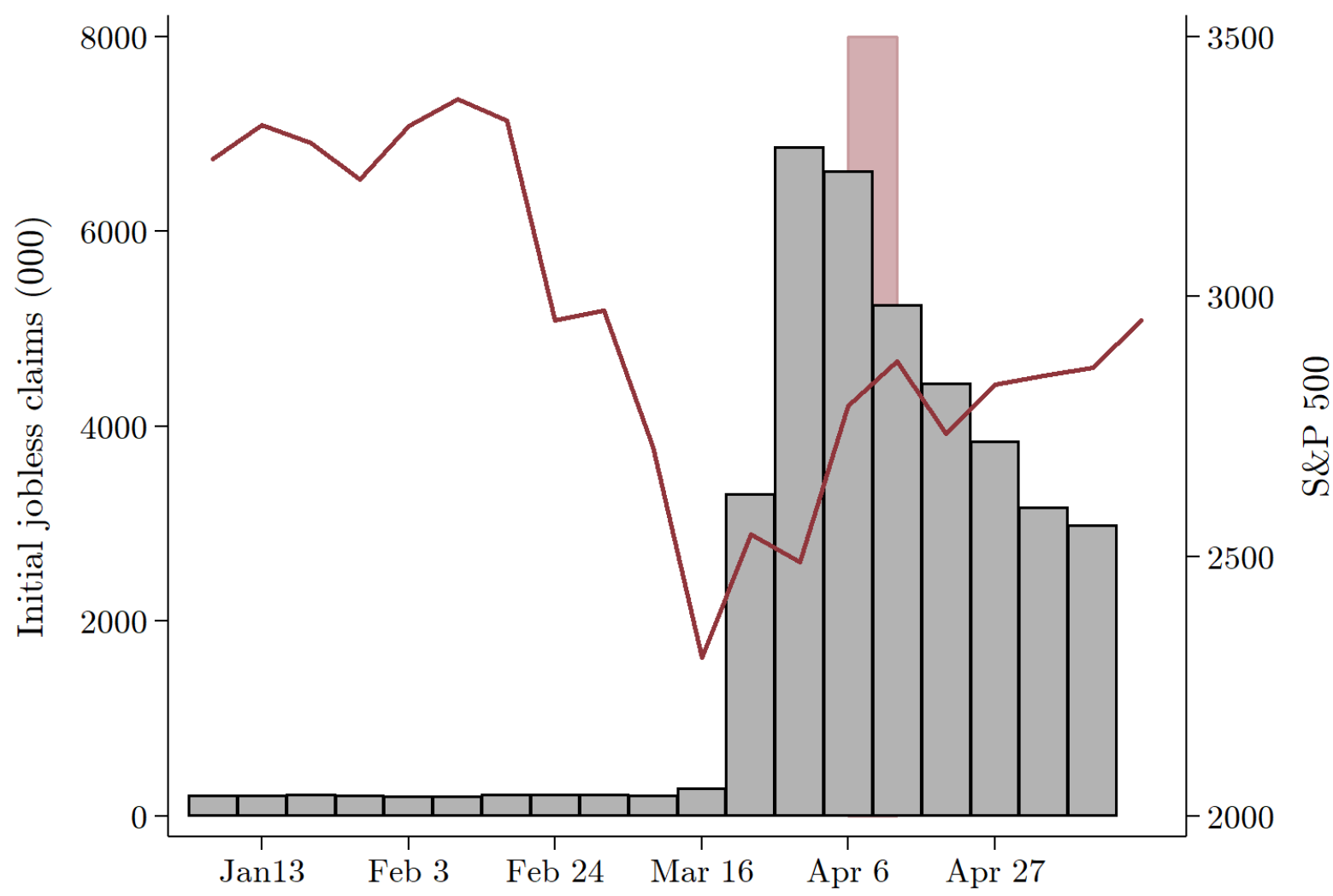

Notes: This figure displays the number of initial jobless claims (in thousands, left axis) and the development of the S\&P500 stock market index (index points, right axis) over the first 19 weeks in 2020, on a weekly basis. The April 6-13 survey period is highlighted in light red.

\footnotetext{
${ }^{1}$ Tobin Hanspal, Department of Finance, Accounting and Statistics, WU Vienna University of Economics and Business, e-mail: tobin.hanspal@wu.ac.at

${ }^{2}$ Annika Weber, Department of Finance, Goethe University Frankfurt, e-mail: annika.weber@hof.unifrankfurt.de

${ }^{3}$ Johannes Wohlfart, Department of Economics and CEBI, University of Copenhagen, CESifo, e-mail: johannes.wohlfart@econ.ku.dk
} 
Figure A2: Information Treatment FinCrisisInfo

You estimated that stock prices recovered to their pre-crisis level 5 years after the

beginning of their drop in October 2007.

We now provide you with information on the actual development of stock prices during the

Financial Crisis that started in 2007.

Starting from the beginning of the drop in stock prices in October 2007, it took about $51 / 2$

years until stock prices recovered to their pre-crisis level in March 2013.

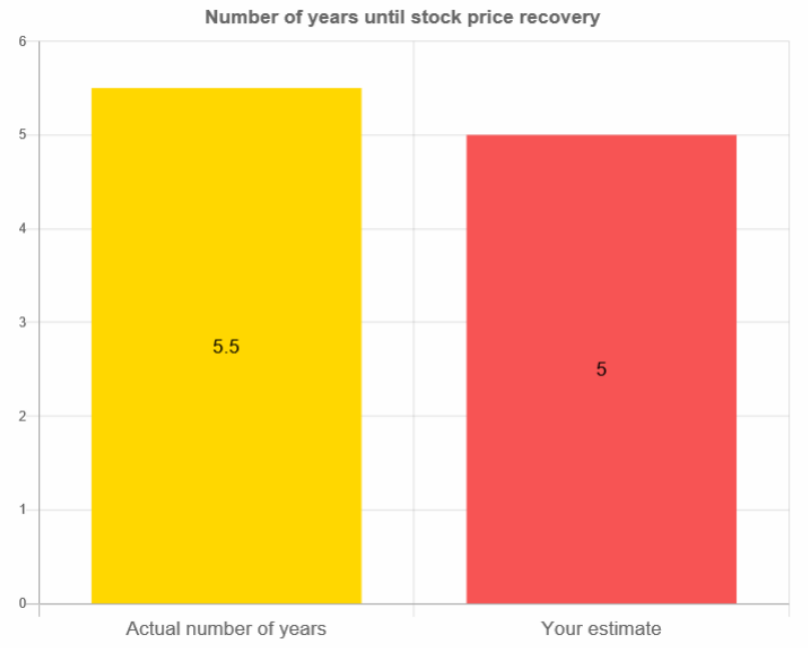

Source: The number is based on the time that the stock market index S\&P500 needed to recover to its pre-crisis level

Note: You will be able to go to the next slide after you have spent a few seconds on this slide.

Notes: This figure illustrates the information treatment screen, providing an example of the FinCrisisInfo treatment arm. The information treatment includes a dynamic figure contrasting the respondent's prior belief (in dark orange, on the right) with the actual number of years it took for the US stock market to recover to its levels before the 2007-2009 Financial Crisis (in yellow, on the left). Recovery durations for the three different information treatments FinCrisisInfo, BlackMondayInfo and DotComInfo are calculated based on monthly time series data of the S\&P500. 
Figure A3: Financial assets and incomes across groups
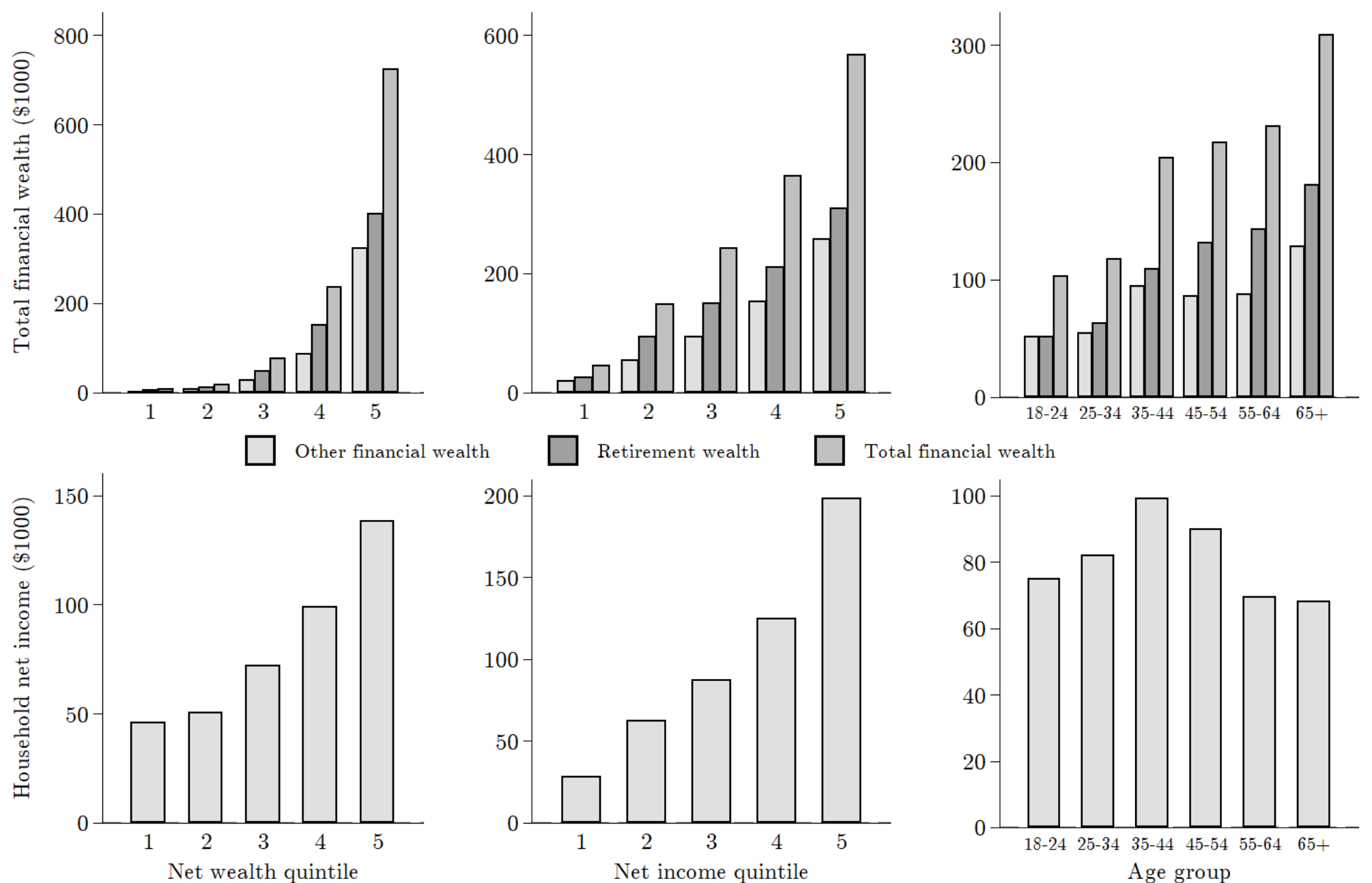

Notes: This figure displays the average value of financial assets (top row) and gross household income during the first quarter of 2020 (bottom row), by quintile of the pre-crisis net worth distribution (left column), by quintile of the pre-crisis net income distribution (middle column) and by age group (right column). Values of financial assets are displayed separately for financial assets outside of retirement accounts, for financial assets in retirement accounts, and for the combined value of all financial assets. The sample is the full sample without missings in the relevant survey questions. 
Figure A4: Participation and stock share of financial wealth across groups
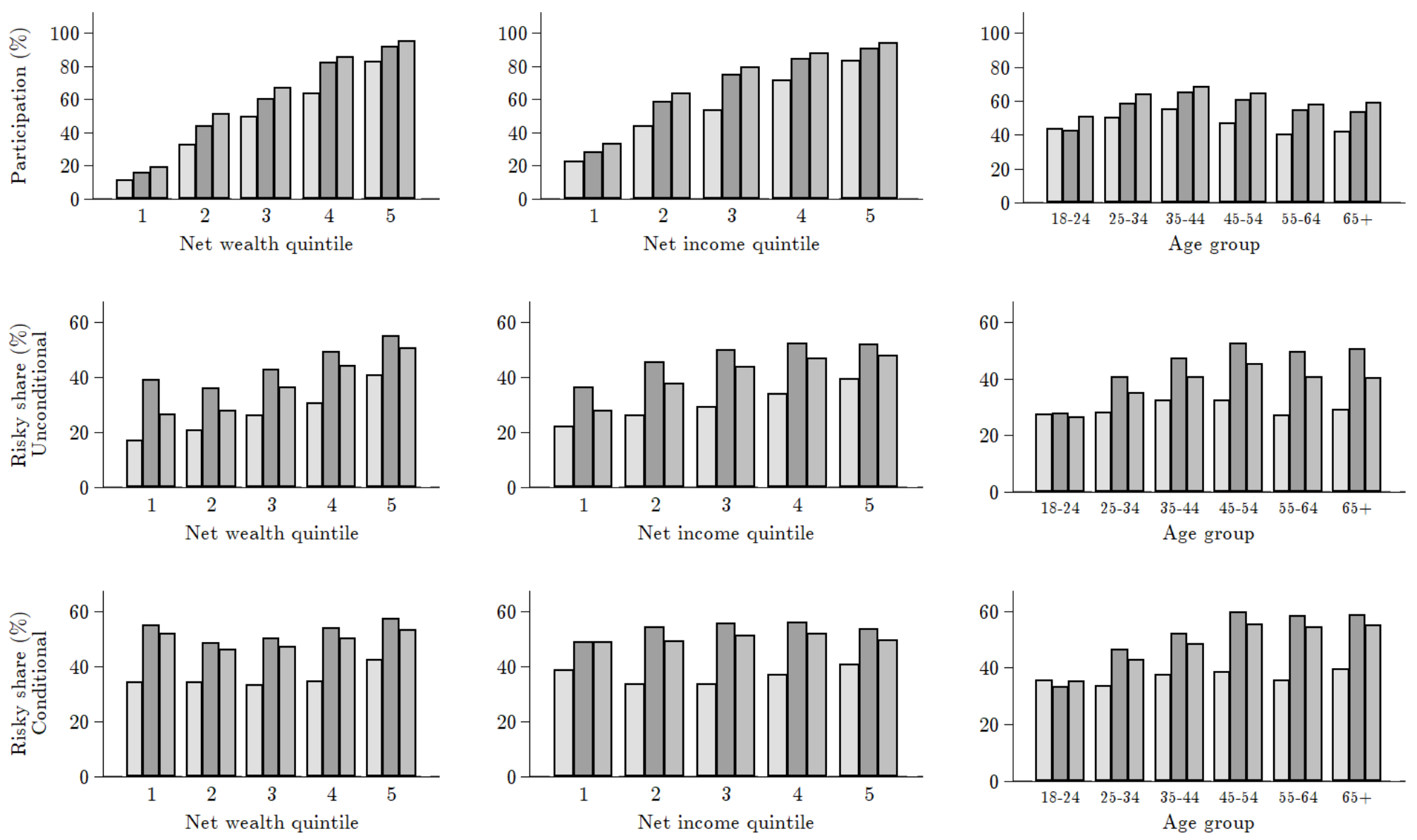

$\square$ Other financial wealth

$\square$ Retirement wealth

Total financial wealth

Notes: This figure displays participation, and the share of financial wealth held, in stocks or mutual funds by quintiles of pre-crisis net wealth (left column) and of pre-crisis net income, (middle), and by age group (right), respectively. The top row plots the rate of participation in stocks and stock mutual funds in the full sample. The middle row plots the unconditional equity share, and the bottom plots the conditional equity share including only respondents that report positive holdings of stocks or stock mutual funds as of January 2020. Equity shares are displayed separately for financial assets outside retirement accounts, for financial assets in retirement accounts, and for the combined value of financial assets. The sample includes all respondents without missings in the relevant survey questions. 
Figure A5: Income and wealth shocks across groups
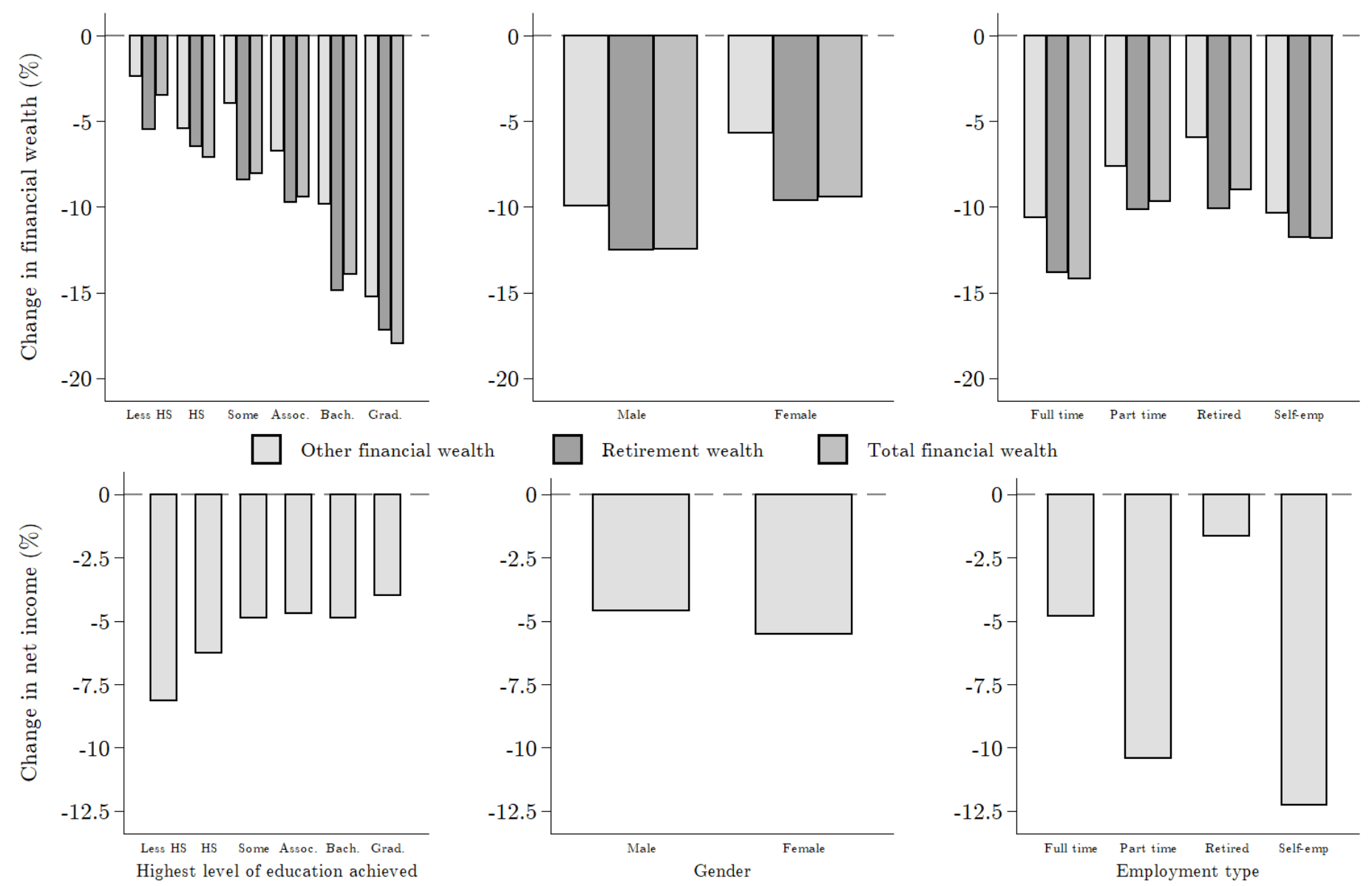

Notes: This figure displays the change in the value of financial assets due to the February/March 2020 stock market drop until the survey date in percentage terms as amounts in USD (top panel) and unexpected changes in net household incomes during the first quarter of 2020 in percentages and USD amounts (bottom panel), by highest level of education achieved (left column), gender (middle column), and pre-crisis employment type (right column). Changes in the value of financial assets are displayed separately for financial assets outside of retirement accounts, for financial assets in retirement accounts, and for the combined value of all financial assets. Changes in value of financial assets are net capital losses for the majority of respondents, and net capital gains for a small fraction of respondents. We trim reported shocks to income and financial wealth at the 2nd and 98th percentiles. The sample is the full sample without missings in the relevant survey questions. Note that the average percent reduction in overall financial wealth can be larger than both average percent reductions for the individual components. This is due to the fact that we coded those with no wealth in a given category as having experienced a shock of zero percent in that category. These cases occur particularly in groups with lower wealth holdings. 
Figure A6: Conditional wealth shocks across groups (Financial wealth >0)
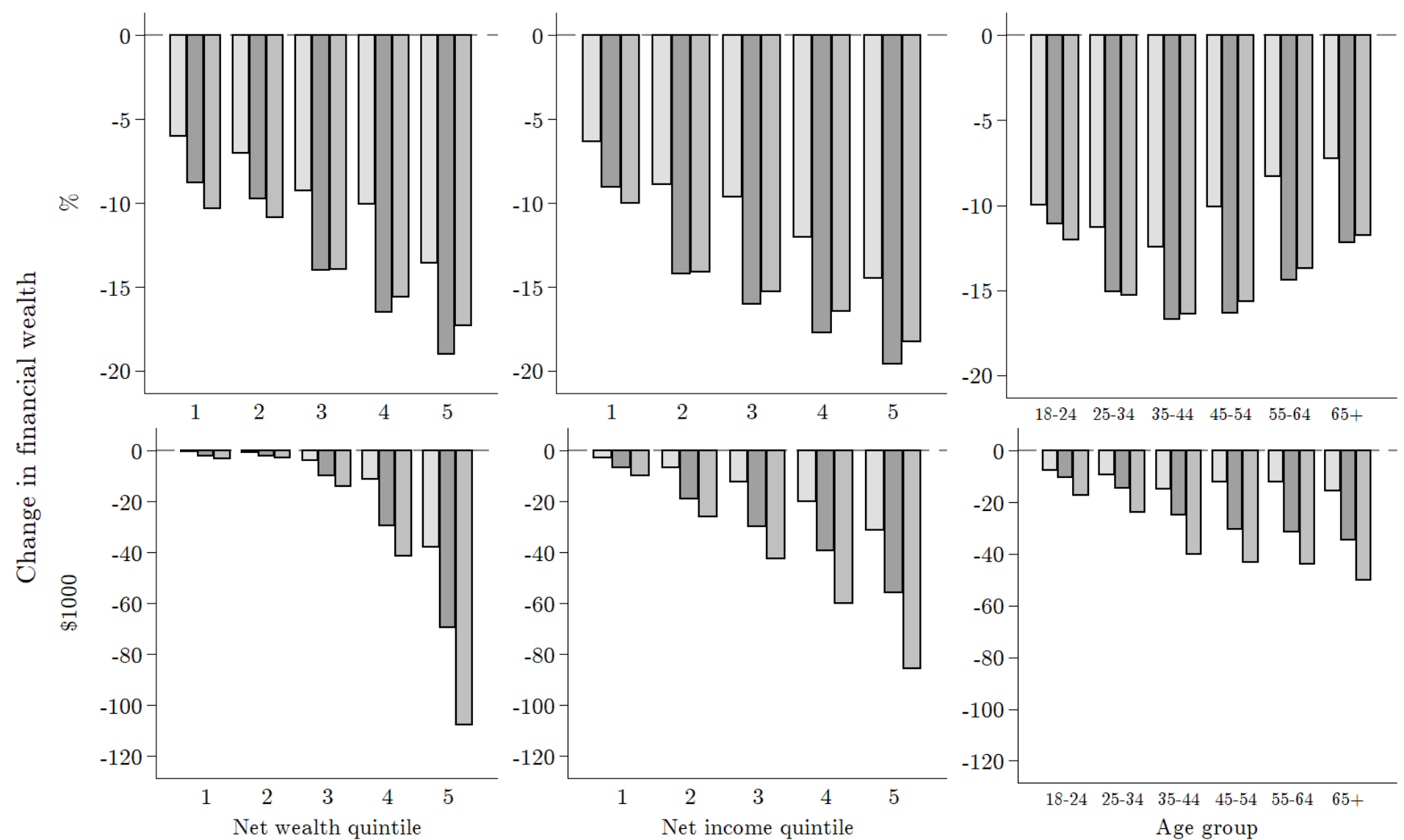

Other financial wealth

Retirement wealth

Total financial wealth

Notes: This figure displays the change in the value of financial assets due to the February/March 2020 stock market drop until the survey date in percentage terms and as amounts in USD, by quintile of the pre-crisis net worth distribution (left column), by quintile of the pre-crisis net income distribution (middle column) and by age group (right column). Changes in the value of financial assets are displayed separately for financial assets outside of retirement accounts, for financial assets in retirement accounts, and for the combined value of all financial assets. The values are conditional on positive financial wealth in January 2020 . Changes in the value of financial assets are net capital losses for the majority of respondents, and net capital gains for a small fraction of respondents. We trim reported shocks to financial wealth at the 2nd and 98th percentiles. The sample is the full sample without missings in the relevant survey questions. Note that the average percent reduction in overall financial wealth can be larger than both average percent reductions for the individual components. This is due to the fact that we coded those with no wealth in a given category as having experienced a shock of zero percent in that category. These cases occur particularly in groups with lower wealth holdings. 
Figure A7: Conditional wealth shocks across groups (Risky share $>0$ )
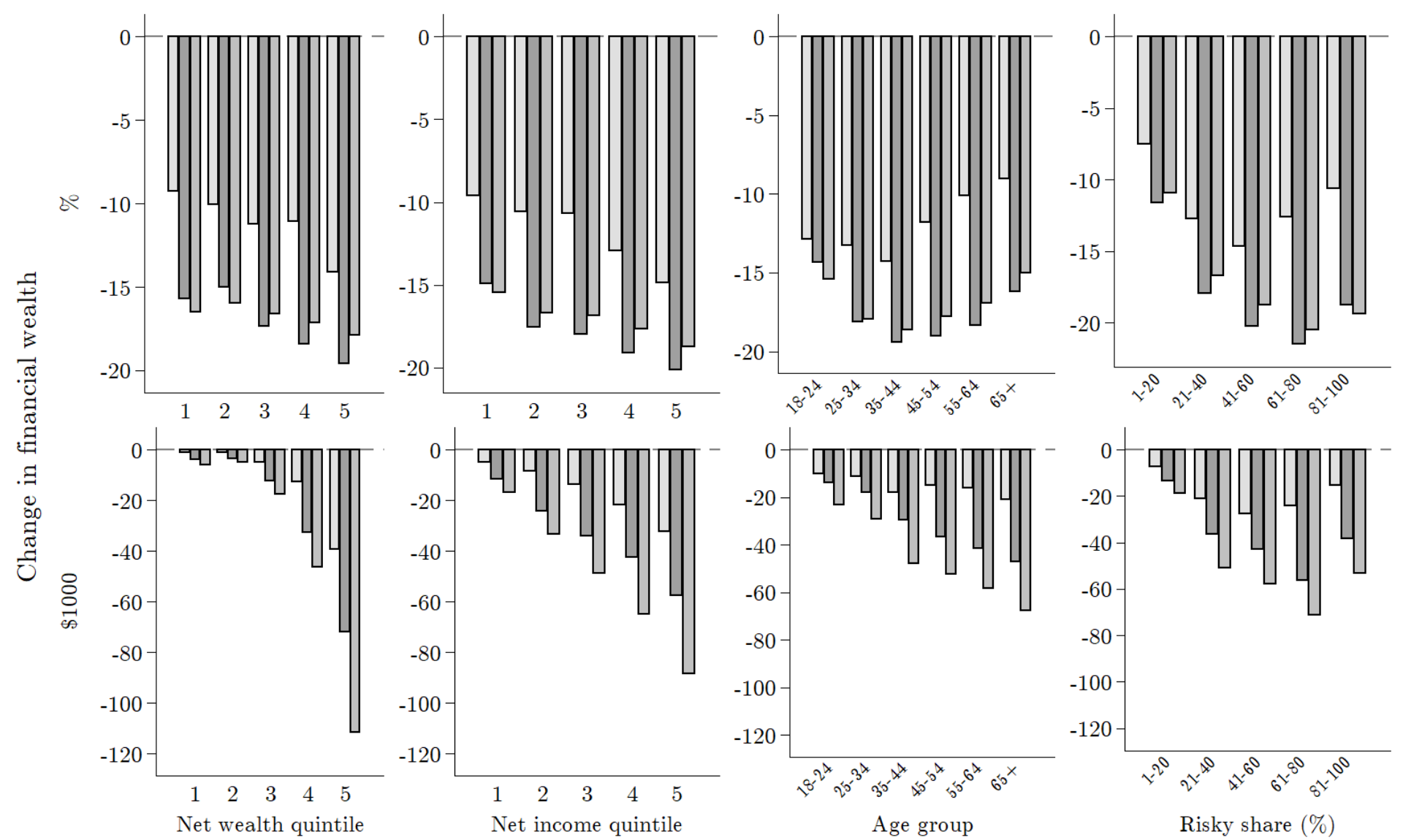

Other financial wealth

Retirement wealth

Total financial wealth

Notes: This figure displays the change in the value of financial assets due to the February/March 2020 stock market drop until the survey date in percentage terms, and as amounts in USD, by quintile of the pre-crisis net worth distribution (left column), by quintile of the pre-crisis net income distribution (second column), by age group (third column), and by bin of the equity share in total financial wealth. Changes in the value of financial assets are displayed separately for financial assets outside of retirement accounts, for financial assets in retirement accounts, and for the combined value of financial assets. The values are conditional on positive equity investments in January 2020. Changes in the value of financial assets are net capital losses for the majority of respondents, and net capital gains for a small fraction of respondents. We trim reported shocks to financial wealth at the 2 nd and 98 th percentiles. The sample is the full sample without missings in the relevant survey questions. Note that the average percent reduction in overall financial wealth can be larger than the average percent reductions for both individual components. This is due to the fact that we coded those with no wealth in a given category as having experienced a shock of zero percent in that category. These cases occur particularly in groups with lower wealth holdings. 
Figure A8: Wealth shocks across groups by risky share

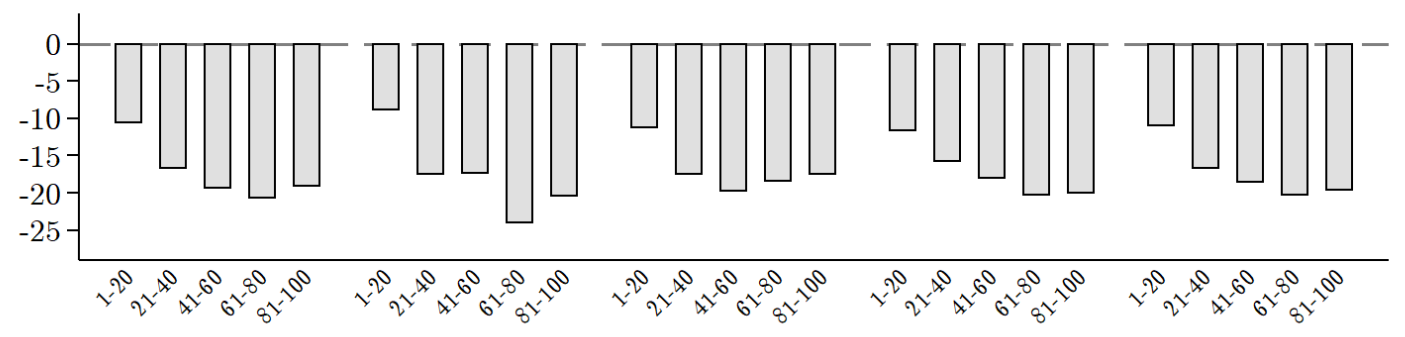

1

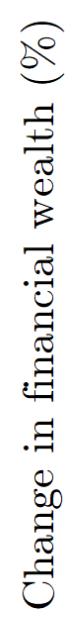

1
2

Net wealth quintile
4

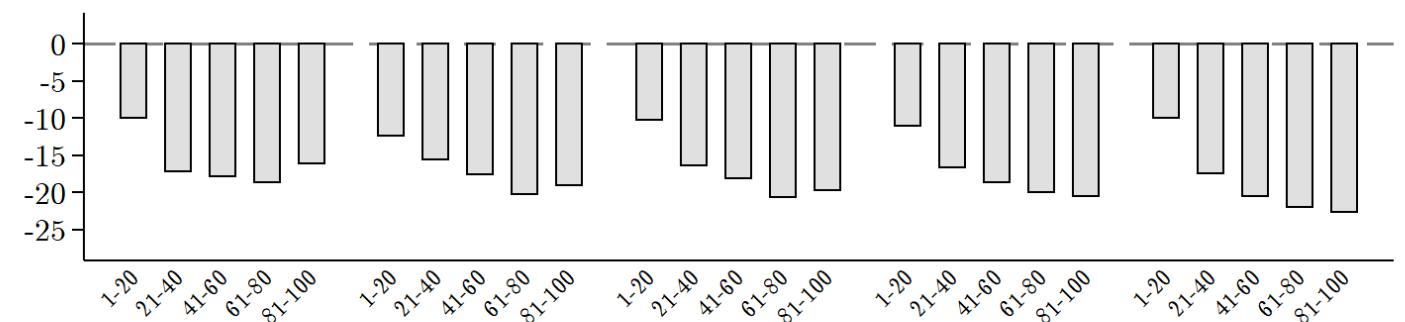

2

3

4

5

Net income quintile

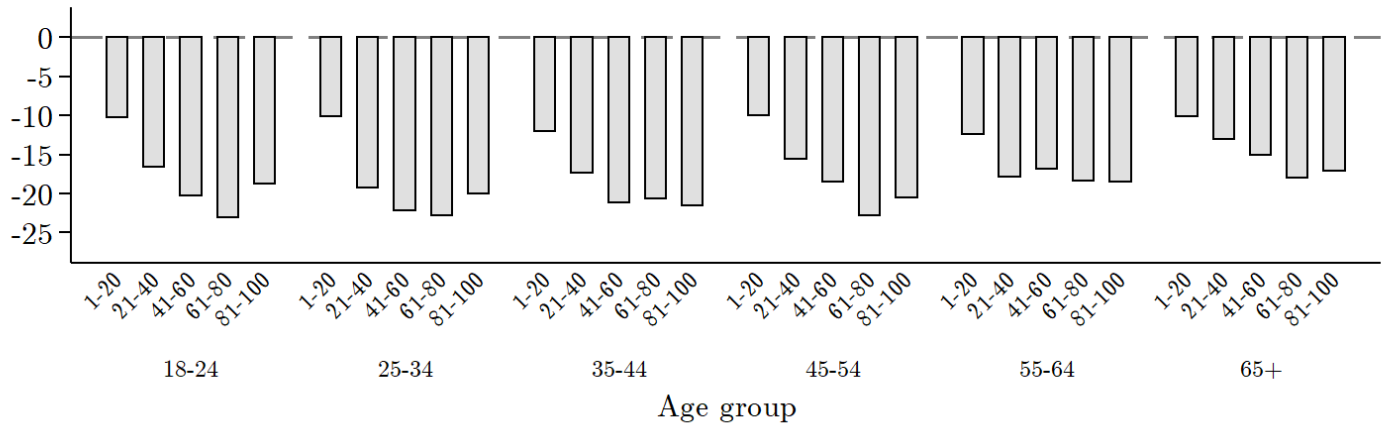

January 2020 risky share allocation

Notes: This figure displays the change in the value of financial assets due to the February/March 2020 stock market drop until the survey date in percentage terms by equity portfolio share bin, separately by quintile of the pre-crisis net worth distribution (top row), by quintile of the pre-crisis net income distribution (middle row), by age group (bottom row). Changes in the value of financial assets are for the combined value of financial assets inside and outside of retirement accounts. The values are conditional on positive equity investments in January 2020. Changes in the value of financial assets are net capital losses for the majority of respondents, and net capital gains for a small fraction of respondents. We trim reported shocks to financial wealth at the 2 nd and 98 th percentiles. The sample is the full sample without missings in the relevant survey questions. 
Figure A9: Job losses across groups
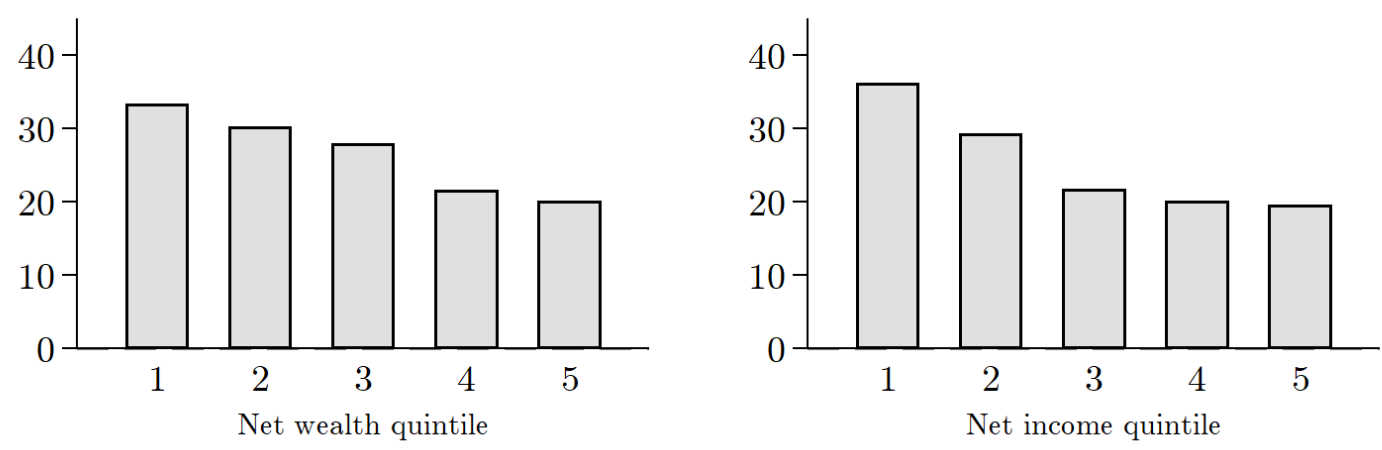

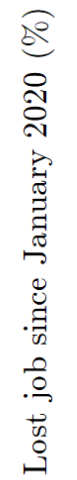
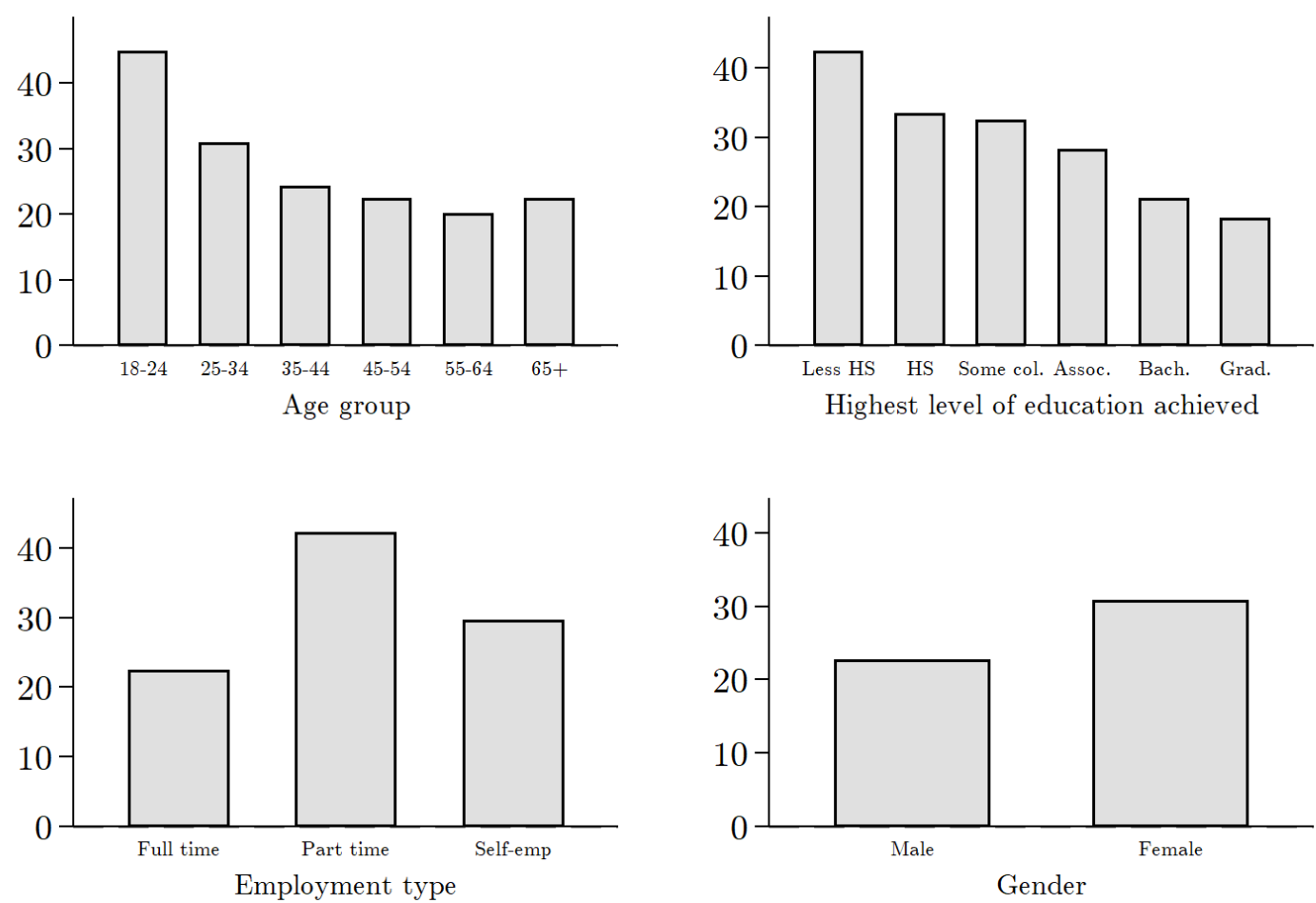

Notes: This figure displays the percentage of respondents who lost their job since January 2020 by precrisis net wealth quintile (top left), pre-crisis net income quintile (top right), age (middle left), education (middle right), pre-crisis employment type (bottom left), and gender (bottom right). The question is presented only to respondents who report to have been employed as of January 2020. The sample is the full sample without missings in the relevant survey questions. 
Figure A10: Effects of wealth and income shocks on expected spending
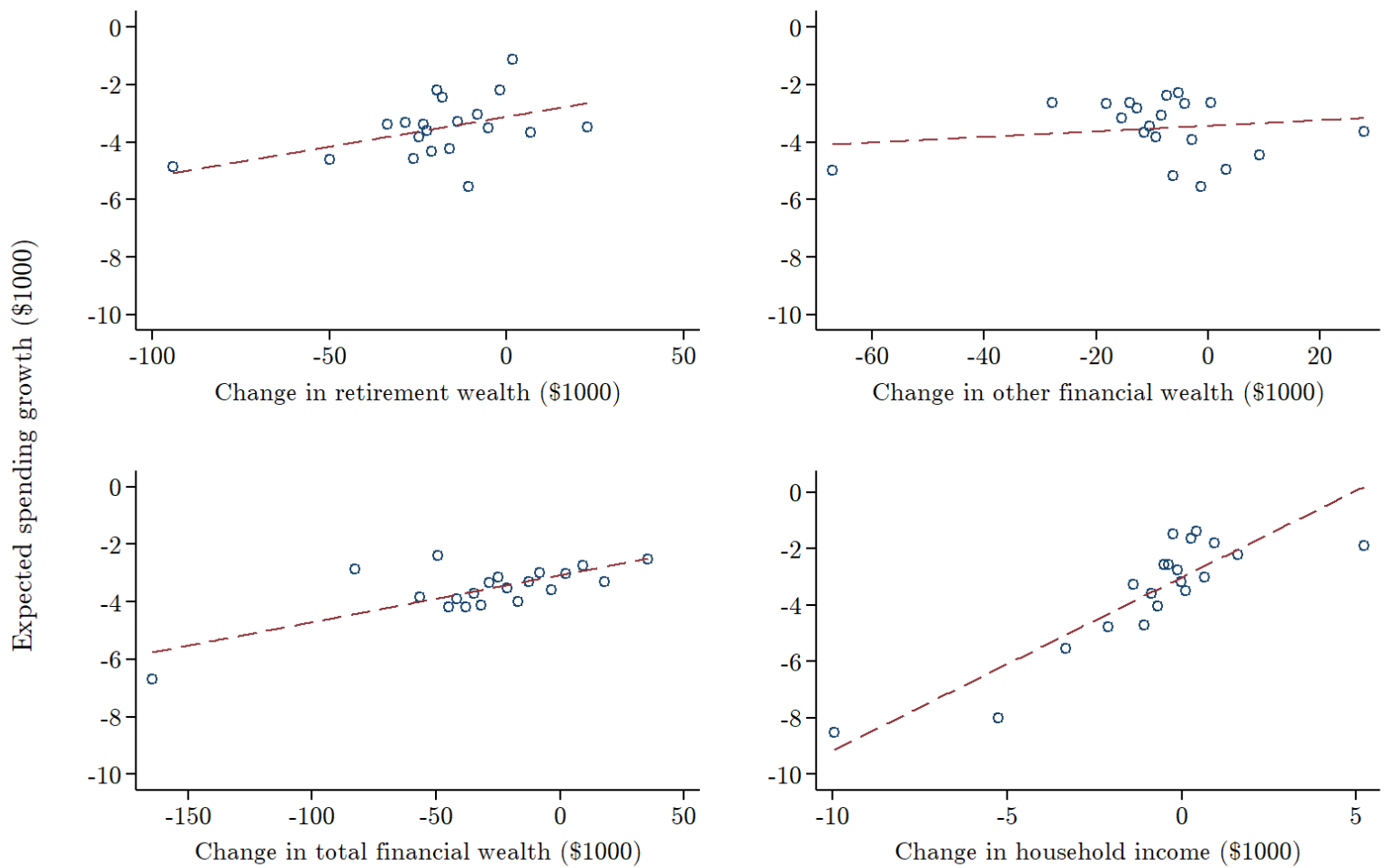

Notes: This figure shows binned scatter plots of the association of shocks to the respondent's household financial wealth and net income with expected growth of total nominal household spending in 2020 compared to 2019. The plots in the top row and in the bottom right are based on specification 2 shown in Table 3, which jointly includes shocks to income, retirement financial wealth and other financial wealth. The plot in the bottom left is based on a similar specification replacing the shocks to financial wealth in retirement accounts and in non-retirement accounts with the shock to overall financial wealth. The outcome is expected household spending growth in dollars, trimmed at the 2nd and 98th percentiles. Dollar changes are constructed from survey questions for retirement and other financial wealth and for income (assuming that the respondent expected a quarter of her 2019 income for the first quarter of 2020), and for spending from the survey question on percent changes and estimates of the level of spending of different groups in 2019 from the CEX. All specifications are based on respondents in the four control arms, who have not received any information. All specifications control for gender, age, employment status, being the main earner, being financial decision-maker, party affiliation, log net household income, logs of retirement wealth, of other financial wealth, of real estate wealth, and of debt, borrowing constraints, stock market participation, the equity share in total financial assets, investment experience, Census region, survey date, and the survey arm. 
Figure A11: Effects of income shocks on expected spending: Heterogeneity
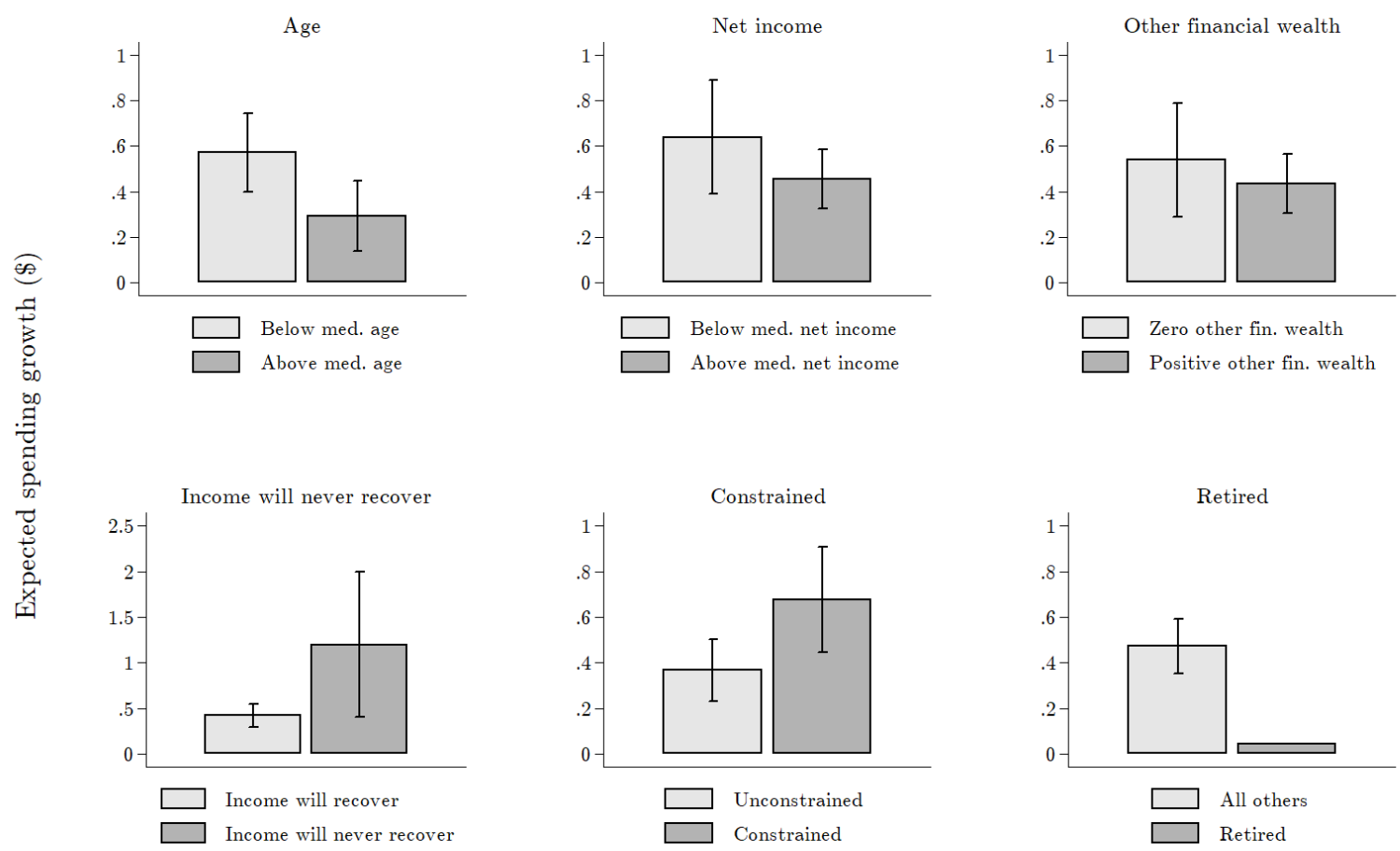

Notes: This figure shows heterogeneity in the effect of income shocks on expected growth of total nominal household spending in 2020 compared to 2019 across groups. The plots are based on the 2SLS specification shown in Table 3 column 3, where the respondent's expected dollar change in household income from 2019 to 2020 is instrumented with the unexpected shock to household income in the first quarter, estimated for different subsamples. The different panels show median splits (below and equal to median vs. strictly above median) according to age (top left) and pre-crisis household net income (top middle), by an indicator (0 vs. 1) for holding other (non-retirement) financial wealth in January 2020 (top right), by an indicator for believing household income will never recover (bottom left), by an indicator for the respondent's household facing credit constraints (bottom middle), and being retired (bottom right). The outcome is expected household spending growth in dollars, trimmed at the 2nd and 98th percentiles. Dollar changes are constructed from survey questions for retirement and other financial wealth and for income (assuming that the respondent expected a quarter of her 2019 income in the first quarter of 2020), and for spending from the survey question on percent changes and estimates of the level of spending of different groups in 2019 from the CEX. In the bottom right panel we do not include confidence bands as the interval is large and insignificant. For all others we include $90 \%$ confidence intervals. All specifications are based on respondents in the four control arms, who have not received any information. All specifications control for gender, age, employment status, being the main earner, being financial decision-maker, party affiliation, log net household income, logs of retirement wealth, of other financial wealth, of real estate wealth, and of debt, borrowing constraints, stock market participation, the equity share in total financial assets, investment experience, Census region, survey date, and the survey arm. 
Figure A12: Effects of wealth shocks on expected spending: Heterogeneity
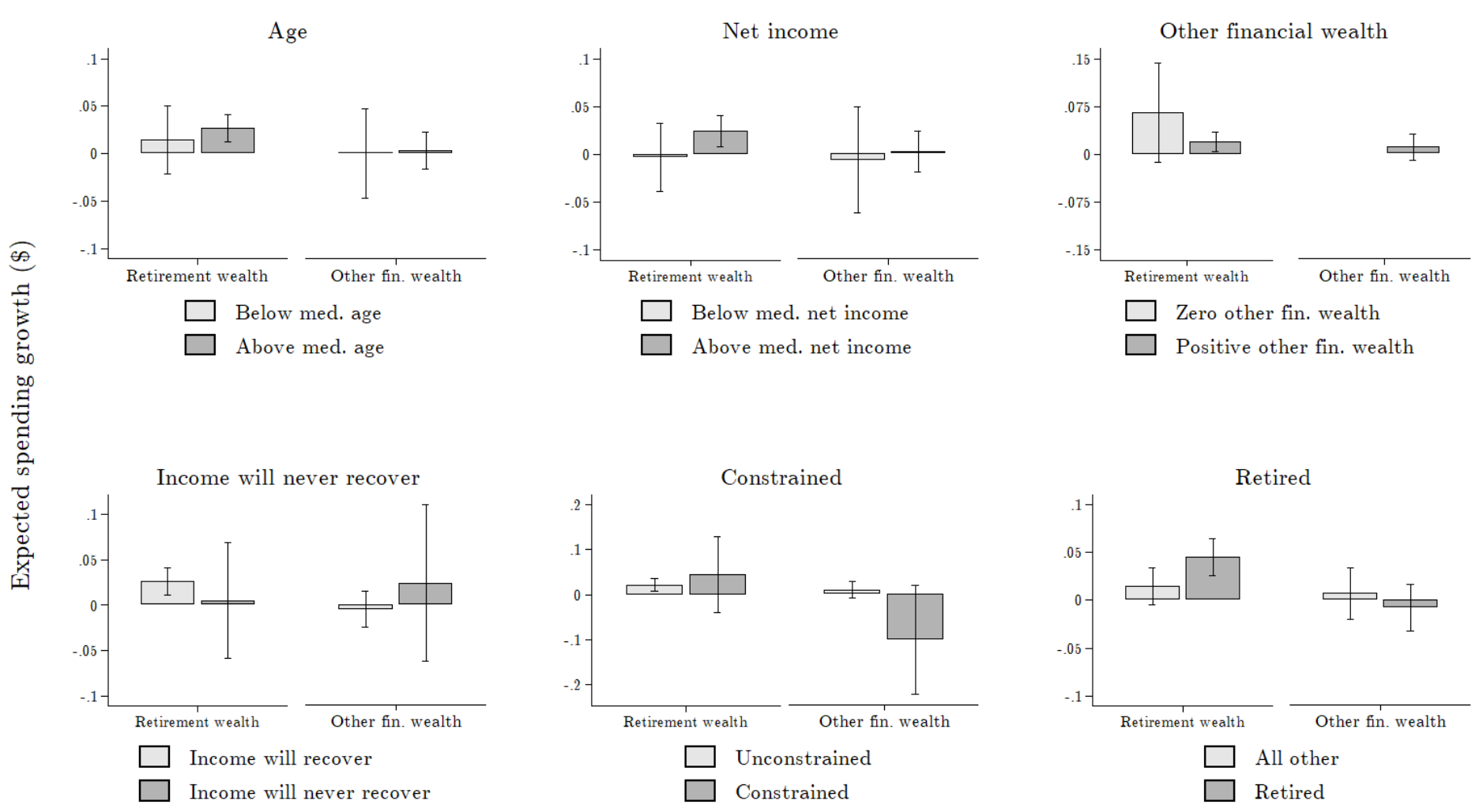

Notes: This figure shows heterogeneity in the association of shocks to the respondent's household retirement financial wealth and non-retirement financial wealth and the expected growth of total nominal household spending in 2020 compared to 2019. The plots for wealth shocks are based on the reduced-form specification controlling for the first quarter-income shock shown in Table 3 column 2, estimated for different subsamples. The outcome is expected household spending growth in dollars, trimmed at the 2nd and 98th percentiles. Dollar changes are constructed from survey questions for retirement and other financial wealth and for spending from the survey question on percent changes and estimates of the level of spending of different groups in 2019 from the CEX. We plot coefficients on changes to a respondent's household retirement financial wealth and other financial wealth by median splits (below and equal to median vs. strictly above median) according to age (top left) and pre-crisis household net income (top middle), by an indicator (0 vs. 1) for holding other (non-retirement) financial wealth in January 2020 (top right), by an indicator for believing individual income will never recover (bottom left), by an indicator for the respondent's household facing credit constraints (bottom middle), and by being retired (bottom right). 90\% confidence intervals are displayed in all figures. All specifications are based on respondents in the four control arms, who have not received any information. All specifications control for gender, age, employment status, being the main earner, being financial decisionmaker, party affiliation, log net household income, logs of retirement wealth, of other financial wealth, of real estate wealth, and of debt, borrowing constraints, stock market participation, risky portfolio share, investment experience, Census region, survey date, and the survey arm. 
Figure A13: Effects of wealth and income shocks on economic plans: Heterogeneity I
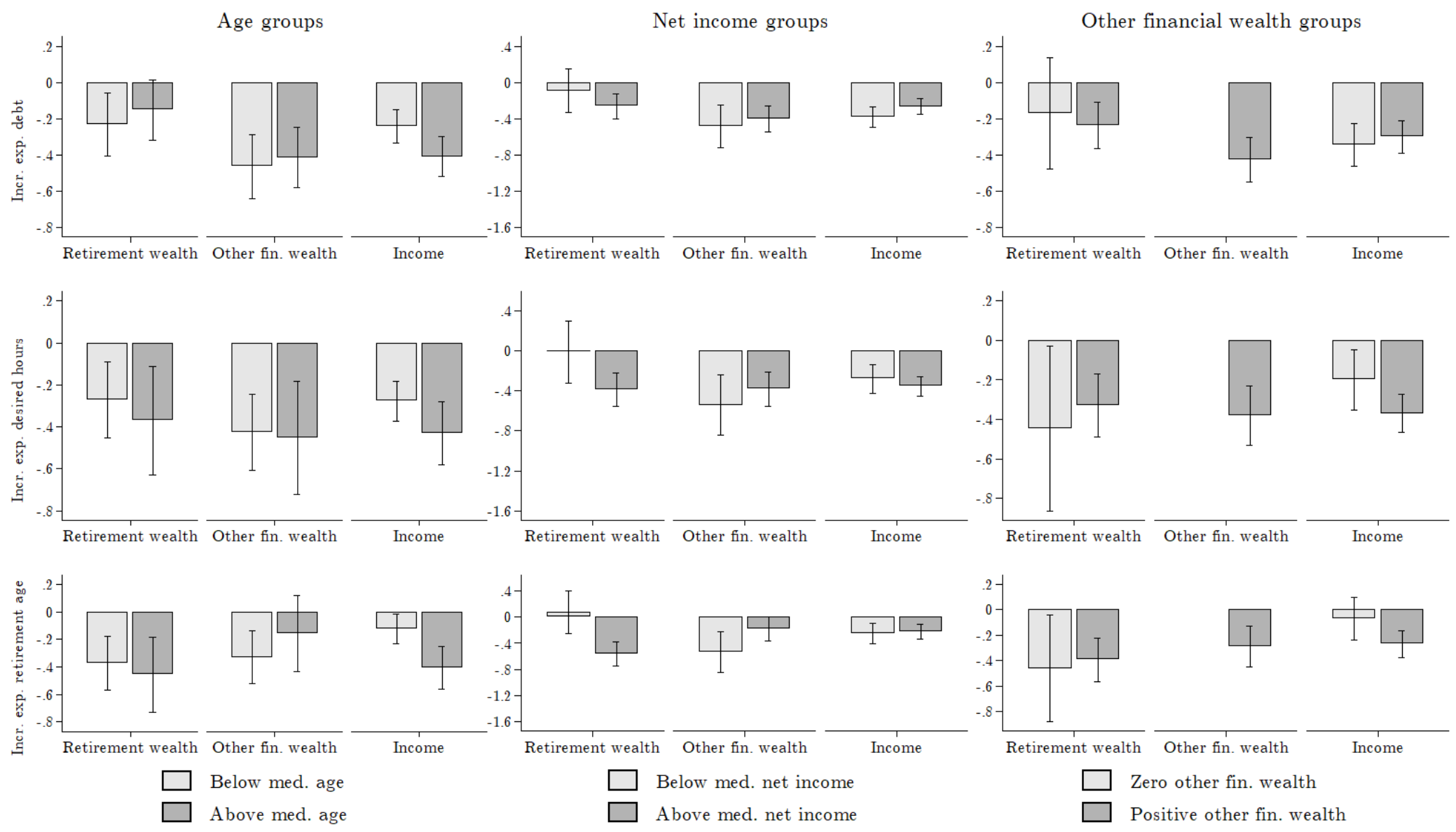

Notes: This figure shows heterogeneity in the effect of shocks to the respondent's household financial wealth and net income on expected economic decisions. We plot the coefficients from specifications regressing indicators for whether the coronavirus crisis increases the respondent's expectations about outstanding household debt by the end of 2020 (top row), expected desired working hours over the next years (middle row) and expected retirement age (bottom row), all coded as 0 or 100 , on changes to a household's retirement financial wealth, other financial wealth, and net household income. We plot these coefficients across columns by median splits (below and equal to median vs. strictly above median) according to age (left column) and pre-crisis household net income (middle), and by an indicator (0 vs. 1) for holding other (non-retirement) financial wealth in January 2020 (right). 90\% confidence intervals are displayed in all figures. All specifications are based on respondents in the four control arms, who have not received any information. All specifications control for gender, age, employment status, being the household's main earner, being the household's financial decision-maker, party affiliation, log net household income, logs of retirement wealth, of other financial wealth, of real estate wealth, and of debt, borrowing constraints, stock market participation, the share of equity in total financial assets, investment experience, Census region, survey date, and the survey arm. 
Figure A14: Effects of wealth and income shocks on economic plans: Heterogeneity II

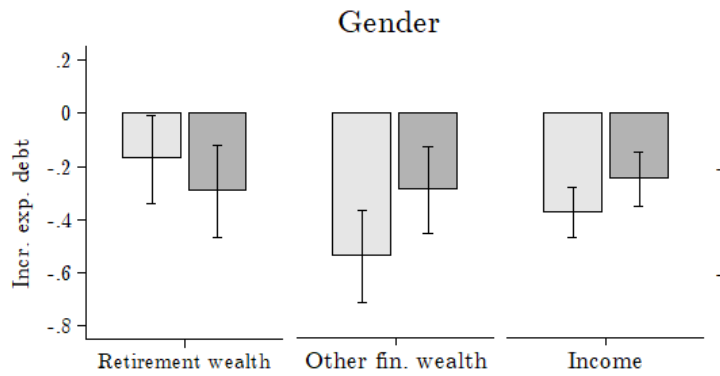

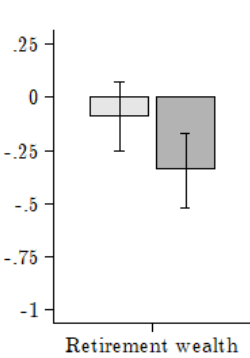

Education
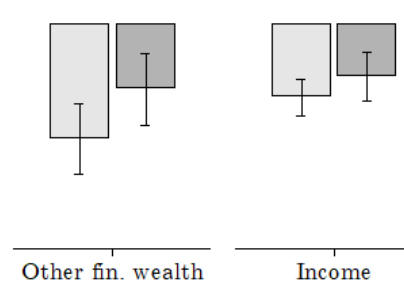

Income
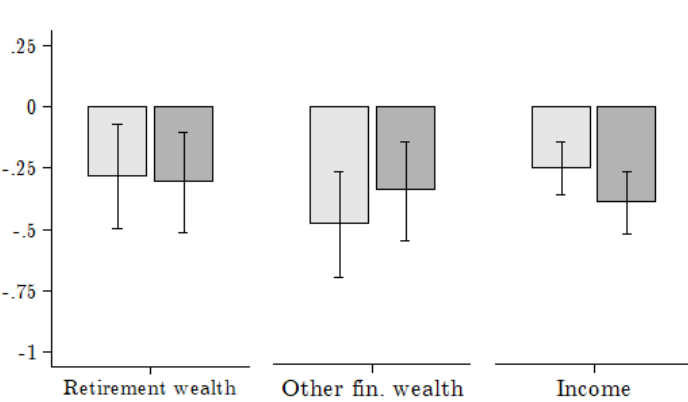

Income
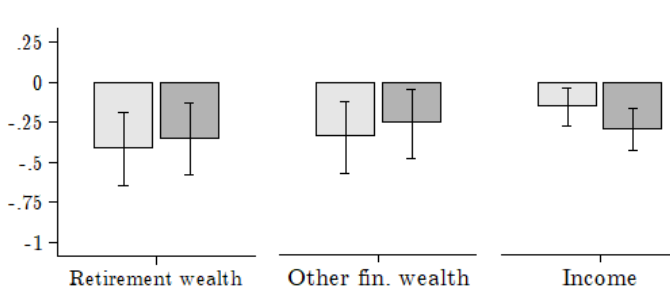

Income

$$
\text { Retirement wealth }
$$

Other fin. wealth

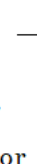

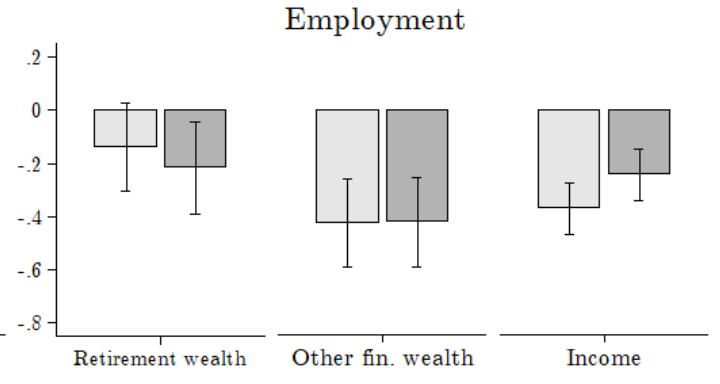
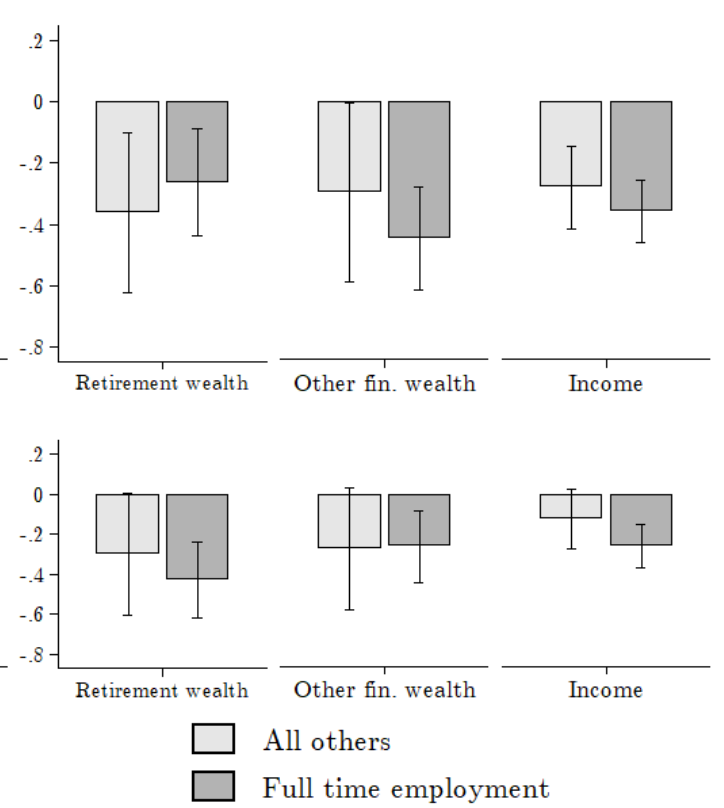

Notes: This figure shows heterogeneity in the effect of shocks to the respondent's household financial wealth and net income on expected economic decisions. We plot the coefficients from specifications regressing indicators for whether the coronavirus crisis increases the respondent's expectations about outstanding household debt by the end of 2020 (top row), expected desired working hours over the next years (middle row) and expected retirement age (bottom row), all coded as 0 or 100, on changes to a household's retirement financial wealth, other financial wealth, and net household income. We plot these coefficients across columns by indicators for gender (left column), education of at least a bachelors degree (middle), and being full-time employed pre-crisis (right). 90\% confidence intervals are displayed on all figures. All specifications are based on respondents in the four control arms, who have not received any information. All specifications control for gender, age, employment status, being the household's main earner, being the household's financial decision-maker, party affiliation, log net household income, logs of retirement wealth, of other financial wealth, of real estate wealth, and of debt, borrowing constraints, stock market participation, the equity share in total financial assets, investment experience, Census region, survey date, and the survey arm. 
Figure A15: Effects of wealth and income shocks on economic plans
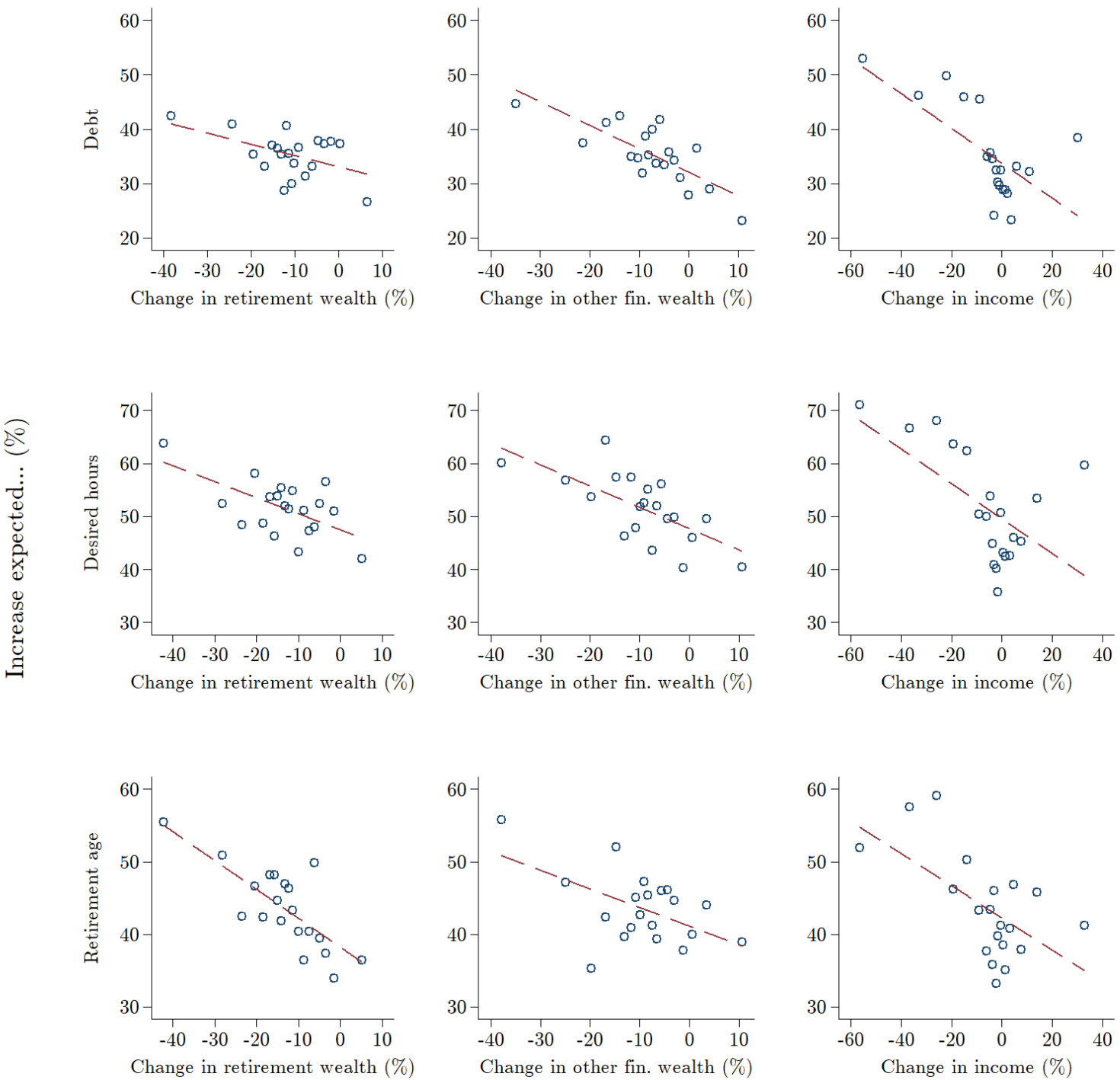

Notes: This figure shows binned scatter plots of the association of shocks to the respondent's household financial wealth and net income with expected economic decisions. The outcomes are a dummy indicating whether the coronavirus crisis increases the respondent's expectations about outstanding household debt by the end of 2020 (left column), expected desired working hours over the next years (middle column, only if in labor force), or expected retirement age (right column, only if in labor force), all coded as 0 or 100 . The underlying regressions are specifications 4,5 , and 6 in Table 3 , which jointly include changes to retirement financial wealth, to other financial wealth, and to household net income. For each outcome (debt, desired working hours, and retirement age), we plot coefficients on changes in retirement wealth (top), changes in other financial wealth (middle), and by changes in household income (bottom) in percentage terms, respectively. All specifications control for all other changes to household income and/or wealth, trimmed at the 2nd and 98th percentiles, gender, age, employment status, being the main earner, being financial decision-maker, party affiliation, log net household income, log of total financial wealth, of real estate wealth, and of debt, share of total financial wealth in retirement accounts, borrowing constraints, stock market participation, stock shares in retirement and other accounts, investment experience, Census region, survey date, and the survey arm. All specifications are based on respondents in the four control arms, who have not received any information. 
Figure A16: Expected duration of recovery across groups
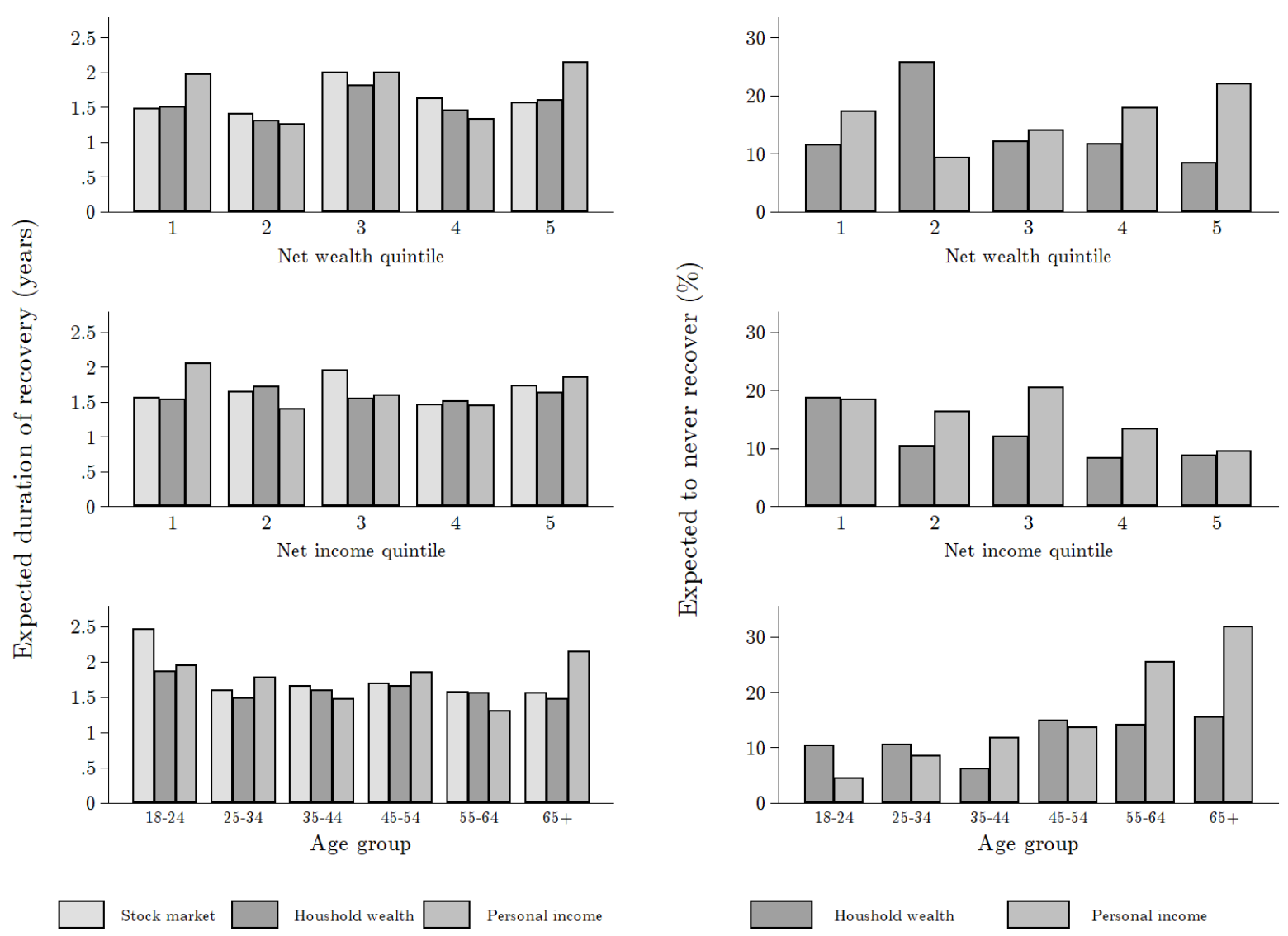

Notes: This figure displays respondents' subjective expectations about the duration of the recovery in years for the US stock market, the respondent's pre-crisis household net wealth, and the respondent's pre-crisis household net income (left column) and the fractions of respondents who believe that their household net wealth or income will never recover (right column) by quintile of the pre-crisis net wealth distribution (top row), by quintile of the pre-crisis net household income distribution (middle row), and by age group (bottom row). The figures on expected recovery duration of the stock market and own wealth condition on those who have made financial losses, while the figures on income recovery duration condition on those who have incurred income losses. The sample consists of respondents in the pure control group, who have not received any questions or information on past crashes before answering to the questions on expected recovery duration. 


\section{B Additional tables}

Table A1: Treatment and sample details

\begin{tabular}{lccc}
\hline Treatment & Sample & Information & Respondents \\
\hline \multirow{2}{*}{ Financial Crisis 2007 } & & & \\
& Information & 5.5 years & 1,055 \\
Dot-com bubble & Control & - & 1,050 \\
& Information & 7 years & 1,041 \\
Black Monday & Control & - & 1,063 \\
Pure control & Information & 2 years & 1,091 \\
& Control & - & 1,058 \\
Total & Control & - & 1,089 \\
\hline
\end{tabular}

Notes: The table gives an overview of the various control and treatment arms in the survey. The final number of participants is listed in the column Respondents.

Table A2: Integrity of treatment randomization

\begin{tabular}{|c|c|c|c|c|c|c|c|c|c|}
\hline & $\begin{array}{c}\text { FinCrisis } \\
\text { Info } \\
\end{array}$ & $\begin{array}{c}\text { FinCrisis } \\
\text { Control } \\
\end{array}$ & $\begin{array}{c}\text { DotCom } \\
\text { Info } \\
\end{array}$ & $\begin{array}{c}\text { DotCom } \\
\text { Control } \\
\end{array}$ & $\begin{array}{c}\text { Black } \\
\text { Monday } \\
\text { Info } \\
\end{array}$ & $\begin{array}{c}\text { Black } \\
\text { Monday } \\
\text { Control } \\
\end{array}$ & $\begin{array}{c}\text { Pure } \\
\text { Control } \\
\end{array}$ & & Obs. \\
\hline & (1) & $(2)$ & (3) & $(4)$ & $(5)$ & $(6)$ & $(7)$ & (8) & (9) \\
\hline Female & 0.51 & 0.50 & 0.52 & 0.51 & 0.51 & 0.52 & 0.53 & 0.815 & 7,447 \\
\hline Age & 48.32 & 48.65 & 48.53 & 48.94 & 48.21 & 48.84 & 48.94 & 0.907 & 7,447 \\
\hline $\begin{array}{l}\text { Bachelor's degree } \\
\text { or higher }\end{array}$ & 0.38 & 0.38 & 0.38 & 0.40 & 0.39 & 0.39 & 0.39 & 0.981 & 7,447 \\
\hline $\begin{array}{l}\text { HH income } \\
\text { (gross, USD) }\end{array}$ & 80,074 & 80,836 & 82,281 & 81,628 & 81,753 & 79,662 & 80,472 & 0.939 & 7,417 \\
\hline Republican & 0.37 & 0.37 & 0.39 & 0.36 & 0.36 & 0.36 & 0.37 & 0.817 & 7,447 \\
\hline Democrat & 0.38 & 0.39 & 0.38 & 0.39 & 0.39 & 0.40 & 0.38 & 0.928 & 7,447 \\
\hline Region Midwest & 0.25 & 0.24 & 0.25 & 0.23 & 0.25 & 0.27 & 0.23 & 0.470 & 7,447 \\
\hline - South & 0.33 & 0.30 & 0.35 & 0.34 & 0.33 & 0.33 & 0.34 & 0.190 & 7,447 \\
\hline - West & 0.21 & 0.25 & 0.21 & 0.22 & 0.20 & 0.21 & 0.21 & 0.273 & 7,447 \\
\hline Stock investor & 0.61 & 0.64 & 0.61 & 0.62 & 0.61 & 0.59 & 0.61 & 0.565 & 7,447 \\
\hline
\end{tabular}

Notes: The table shows respondent characteristics across the 7 treatment and control arms. Column 8 shows the p-Value of an F-test that all coefficients are zero when jointly regressing the respective characteristics on all treatment dummies. 
Table A3: Average losses across groups and samples

\begin{tabular}{|c|c|c|c|c|}
\hline \multirow{3}{*}{ Sort } & \multirow{3}{*}{ Sample } & \multicolumn{3}{|c|}{ Difference in losses between 5 th and 1 st quintile (\%) } \\
\hline & & $\begin{array}{l}\text { Other financial } \\
\text { wealth }\end{array}$ & $\begin{array}{l}\text { Retirement } \\
\text { wealth }\end{array}$ & $\begin{array}{l}\text { Total financial } \\
\text { wealth }\end{array}$ \\
\hline & & $(1)$ & $(2)$ & $(3)$ \\
\hline \multirow{3}{*}{ Net wealth } & Unconditional & -11.33 & -15.70 & -13.48 \\
\hline & Financial wealth $>0$ & -7.58 & -10.23 & -6.99 \\
\hline & Stocks $>0$ & -4.81 & -3.85 & -1.37 \\
\hline \multirow{3}{*}{ Net income } & Unconditional & -10.50 & -13.93 & -12.07 \\
\hline & Financial wealth $>0$ & -8.18 & -10.58 & -8.23 \\
\hline & Stocks $>0$ & -5.23 & -5.21 & -3.23 \\
\hline \multirow{3}{*}{ Age group } & Unconditional & 0.21 & -3.74 & -2.67 \\
\hline & Financial wealth $>0$ & 1.72 & -3.28 & -1.68 \\
\hline & Stocks $>0$ & 2.79 & -4.03 & -1.52 \\
\hline
\end{tabular}

Notes: The table shows the difference in percentage financial losses between the 5th and 1st quintile of the distributions of household net wealth and household net income, and between the lowest (18-24) and highest (65 and older) age categories. Differences in the percentage losses are displayed separately for non-retirement financial wealth (column 1), other financial wealth (column 2), and total financial wealth (column 3). We display differences between the two extreme quintiles (age categories) unconditionally for the entire sample, for the subsample of individuals with positive financial wealth holdings as of January 2020, and for the subsample of individuals with positive equity investments as of January 2020. Within each (sub-)sample, we include all respondents with nonmissing survey responses. 
Table A4: Determinants of realized and planned adjustments to stock share: Pure control only

\begin{tabular}{|c|c|c|c|c|c|c|}
\hline & $\begin{array}{l}\text { Changed } \\
\text { stock } \\
\text { share }\end{array}$ & $\begin{array}{l}\text { Increased } \\
\text { stock } \\
\text { share }\end{array}$ & $\begin{array}{l}\text { Decreased } \\
\text { stock } \\
\text { share }\end{array}$ & $\begin{array}{c}\text { Plan change } \\
\text { stock } \\
\text { share }\end{array}$ & $\begin{array}{l}\text { Plan incr. } \\
\text { stock } \\
\text { share }\end{array}$ & $\begin{array}{c}\text { Plan decr. } \\
\text { stock } \\
\text { share }\end{array}$ \\
\hline & (1) & $(2)$ & $(3)$ & (4) & (5) & (6) \\
\hline$\Delta$ Net income $(\%)$ & $\begin{array}{l}-0.203^{*} \\
(0.106)\end{array}$ & $\begin{array}{l}-0.022 \\
(0.115)\end{array}$ & $\begin{array}{l}-0.181 \\
(0.113)\end{array}$ & $\begin{array}{c}-0.267^{* *} \\
(0.122)\end{array}$ & $\begin{array}{c}0.029 \\
(0.142)\end{array}$ & $\begin{array}{c}-0.296^{* * *} \\
(0.110)\end{array}$ \\
\hline$\Delta$ Retirement fin. wealth (\%) & & & & $\begin{array}{c}0.005 \\
(0.181)\end{array}$ & $\begin{array}{l}-0.203 \\
(0.176)\end{array}$ & $\begin{array}{c}0.209 \\
(0.155)\end{array}$ \\
\hline$\Delta$ Other fin. wealth (\%) & & & & $\begin{array}{c}-0.480^{* * *} \\
(0.175)\end{array}$ & $\begin{array}{c}-0.348^{* *} \\
(0.172)\end{array}$ & $\begin{array}{c}-0.132 \\
(0.160)\end{array}$ \\
\hline Ln(Total fin. wealth) & $\begin{array}{c}2.733 \\
(1.740)\end{array}$ & $\begin{array}{l}-1.487 \\
(1.712)\end{array}$ & $\begin{array}{l}4.220^{* *} \\
(1.660)\end{array}$ & $\begin{array}{c}0.960 \\
(1.769)\end{array}$ & $\begin{array}{c}0.109 \\
(1.845)\end{array}$ & $\begin{array}{c}0.851 \\
(1.613)\end{array}$ \\
\hline Stock share in ret. wealth & $\begin{array}{l}-0.073 \\
(0.069)\end{array}$ & $\begin{array}{l}-0.020 \\
(0.061)\end{array}$ & $\begin{array}{l}-0.053 \\
(0.055)\end{array}$ & $\begin{array}{l}-0.106 \\
(0.072)\end{array}$ & $\begin{array}{l}-0.034 \\
(0.063)\end{array}$ & $\begin{array}{c}-0.071 \\
(0.049)\end{array}$ \\
\hline Stock share in ot. fin wealth & $\begin{array}{l}-0.044 \\
(0.065)\end{array}$ & $\begin{array}{l}-0.015 \\
(0.054)\end{array}$ & $\begin{array}{c}-0.029 \\
(0.058)\end{array}$ & $\begin{array}{l}-0.036 \\
(0.065)\end{array}$ & $\begin{array}{l}-0.039 \\
(0.056)\end{array}$ & $\begin{array}{c}0.003 \\
(0.053)\end{array}$ \\
\hline Share ret. in tot. fin. wealth & $\begin{array}{l}-0.074 \\
(0.089)\end{array}$ & $\begin{array}{l}-0.034 \\
(0.086)\end{array}$ & $\begin{array}{c}-0.040 \\
(0.086)\end{array}$ & $\begin{array}{l}-0.092 \\
(0.093)\end{array}$ & $\begin{array}{l}-0.063 \\
(0.090)\end{array}$ & $\begin{array}{c}-0.029 \\
(0.081)\end{array}$ \\
\hline Any loss fin. crisis & $\begin{array}{c}4.355 \\
(5.250)\end{array}$ & $\begin{array}{c}0.934 \\
(5.201)\end{array}$ & $\begin{array}{c}3.421 \\
(4.740)\end{array}$ & $\begin{array}{l}-0.202 \\
(5.343)\end{array}$ & $\begin{array}{c}-4.541 \\
(5.330)\end{array}$ & $\begin{array}{c}4.339 \\
(4.523)\end{array}$ \\
\hline Big loss fin. crisis & $\begin{array}{l}10.581^{*} \\
(5.805)\end{array}$ & $\begin{array}{l}-1.029 \\
(4.675)\end{array}$ & $\begin{array}{c}11.611^{* *} \\
(5.729)\end{array}$ & $\begin{array}{l}-8.162 \\
(5.398)\end{array}$ & $\begin{array}{c}-10.969^{* *} \\
(5.026)\end{array}$ & $\begin{array}{c}2.807 \\
(4.661)\end{array}$ \\
\hline Any loss dot-com & $\begin{array}{l}-6.620 \\
(5.424)\end{array}$ & $\begin{array}{l}-7.927 \\
(5.038)\end{array}$ & $\begin{array}{c}1.307 \\
(4.961)\end{array}$ & $\begin{array}{l}-2.290 \\
(5.387)\end{array}$ & $\begin{array}{c}5.642 \\
(5.251)\end{array}$ & $\begin{array}{c}-7.933^{* *} \\
(3.952)\end{array}$ \\
\hline Big loss dot-com & $\begin{array}{r}-12.558 \\
(7.925)\end{array}$ & $\begin{array}{c}7.262 \\
(6.896)\end{array}$ & $\begin{array}{c}-19.821^{* * *} \\
(6.592)\end{array}$ & $\begin{array}{c}7.637 \\
(8.543)\end{array}$ & $\begin{array}{c}2.022 \\
(8.043)\end{array}$ & $\begin{array}{c}5.615 \\
(6.503)\end{array}$ \\
\hline Any loss Black Monday & $\begin{array}{c}7.533 \\
(6.558)\end{array}$ & $\begin{array}{c}2.634 \\
(5.830)\end{array}$ & $\begin{array}{c}4.899 \\
(5.917)\end{array}$ & $\begin{array}{c}6.042 \\
(6.147)\end{array}$ & $\begin{array}{c}3.738 \\
(5.808)\end{array}$ & $\begin{array}{c}2.303 \\
(4.492)\end{array}$ \\
\hline Big loss Black Monday & $\begin{array}{l}-11.810 \\
(10.551)\end{array}$ & $\begin{array}{c}-14.421^{* *} \\
(6.596)\end{array}$ & $\begin{array}{c}2.611 \\
(9.362)\end{array}$ & $\begin{array}{r}-12.090 \\
(9.951)\end{array}$ & $\begin{array}{c}-10.374 \\
(8.497)\end{array}$ & $\begin{array}{l}-1.716 \\
(6.631)\end{array}$ \\
\hline Male & $\begin{array}{c}11.502^{* *} \\
(4.970)\end{array}$ & $\begin{array}{c}7.733^{*} \\
(4.494)\end{array}$ & $\begin{array}{c}3.769 \\
(4.297)\end{array}$ & $\begin{array}{c}1.098 \\
(4.944)\end{array}$ & $\begin{array}{c}4.701 \\
(4.594)\end{array}$ & $\begin{array}{l}-3.603 \\
(3.779)\end{array}$ \\
\hline At least bachelor & $\begin{array}{l}-22.711 \\
(20.880)\end{array}$ & $\begin{array}{l}-21.361 \\
(22.314)\end{array}$ & $\begin{array}{c}-1.350 \\
(15.922)\end{array}$ & $\begin{array}{c}10.944 \\
(21.657)\end{array}$ & $\begin{array}{l}-11.292 \\
(25.271)\end{array}$ & $\begin{array}{l}22.236^{*} \\
(12.633)\end{array}$ \\
\hline Republican & $\begin{array}{l}-6.972 \\
(4.556)\end{array}$ & $\begin{array}{l}-7.019 \\
(4.352)\end{array}$ & $\begin{array}{c}0.047 \\
(4.268)\end{array}$ & $\begin{array}{c}0.050 \\
(4.445)\end{array}$ & $\begin{array}{l}-0.710 \\
(4.424)\end{array}$ & $\begin{array}{c}0.760 \\
(3.816)\end{array}$ \\
\hline Individual controls & Yes & Yes & Yes & Yes & Yes & Yes \\
\hline Adj. R-squared & .221 & .135 & .057 & .279 & .108 & .102 \\
\hline Observations & 550 & 550 & 550 & 503 & 503 & 503 \\
\hline
\end{tabular}

Notes: This table shows OLS estimates of the determinants of realized and planned adjustments to the share of equities in total financial assets. The outcomes are dummies indicating whether the respondent's household has made any change, has increased or has decreased the equity share in total financial assets since the beginning of the stock market drop (columns 1-3) and dummies indicating plans to change, increase or decrease the equity share in overall financial assets in the weeks after the survey (columns 4-6), all coded as 0 or 100. All specifications are based on the pure control group, which has not received any information and not answered any questions on past crashes, using only respondents who report positive stockholdings as of January 2020. All specifications control for shocks to income, trimmed at the 2nd and 98th percentiles, dummies for having lost any wealth or substantial wealth during past stock market crashes, gender, age, employment status, being the main earner, being financial decision-maker, party affiliation, log net household income, log of total financial wealth, of real estate wealth, and of debt, share of total financial wealth in retirement accounts, borrowing constraints, stock market participation, stock shares in retirement and other accounts, investment experience, Census region, survey date, and the survey arm. Columns 4-6 additionally control for shocks to retirement and other financial wealth, trimmed at the 2 nd and 98 th percentiles. Robust standard errors are reported in parentheses. ${ }^{*}$ denotes significance at the 10 pct., $* *$ at the 5 pct., and $* * *$ at the 1 pct. level. 
Table A5: Income and wealth shocks and expected economic decisions: Pure control only

\begin{tabular}{|c|c|c|c|c|c|c|}
\hline & $\begin{array}{c}\text { Exp. } \\
\text { spend. } \\
\text { growth }(\%) \\
\end{array}$ & $\begin{array}{c}\text { Exp. } \\
\text { spend. } \\
\text { growth }(\$) \\
\end{array}$ & $\begin{array}{c}\text { Exp. } \\
\text { spend. } \\
\text { growth }(\$)\end{array}$ & $\begin{array}{l}\text { Incr. } \\
\text { exp. } \\
\text { debt }\end{array}$ & $\begin{array}{c}\text { Incr. exp. } \\
\text { desired } \\
\text { hours } \\
\end{array}$ & $\begin{array}{l}\text { Incr. exp. } \\
\text { retirement } \\
\text { age }\end{array}$ \\
\hline & (1) & (2) & (3) & (4) & $(5)$ & (6) \\
\hline$\Delta$ Retirement fin. wealth (\%) & $\begin{array}{c}0.018 \\
(0.068)\end{array}$ & & & $\begin{array}{c}-0.148 \\
(0.148)\end{array}$ & $\begin{array}{c}-0.274 \\
(0.188)\end{array}$ & $\begin{array}{c}-0.696^{* * *} \\
(0.195)\end{array}$ \\
\hline$\Delta$ Other fin. wealth (\%) & $\begin{array}{c}-0.061 \\
(0.070)\end{array}$ & & & $\begin{array}{c}-0.443^{* * *} \\
(0.140)\end{array}$ & $\begin{array}{c}-0.371^{* *} \\
(0.176)\end{array}$ & $\begin{array}{c}0.006 \\
(0.179)\end{array}$ \\
\hline$\Delta$ Net income (quarterly, \%) & $\begin{array}{c}0.189^{* * *} \\
(0.048)\end{array}$ & & & $\begin{array}{c}-0.286^{* * *} \\
(0.085)\end{array}$ & $\begin{array}{c}-0.358^{* * *} \\
(0.105)\end{array}$ & $\begin{array}{c}-0.401^{* * *} \\
(0.100)\end{array}$ \\
\hline$\Delta$ Retirement fin. wealth $(\$)$ & & $\begin{array}{c}0.048^{* * *} \\
(0.016)\end{array}$ & $\begin{array}{c}0.039^{* *} \\
(0.017)\end{array}$ & & & \\
\hline$\Delta$ Other fin. wealth $(\$)$ & & $\begin{array}{c}0.011 \\
(0.019)\end{array}$ & $\begin{array}{c}-0.002 \\
(0.021)\end{array}$ & & & \\
\hline$\Delta$ Net income (quarterly, $\$$ ) & & $\begin{array}{c}0.584^{* * *} \\
(0.201)\end{array}$ & & & & \\
\hline$\Delta$ Net income (annual, $\$$ ) & & & $\begin{array}{c}0.536^{* * *} \\
(0.139)\end{array}$ & & & \\
\hline Individual controls & Yes & Yes & Yes & Yes & Yes & Yes \\
\hline Adj. R-squared & .048 & .044 & .114 & .198 & .108 & .124 \\
\hline Observations & 970 & 917 & 906 & 987 & 603 & 603 \\
\hline
\end{tabular}

Notes: This table shows estimates of the association of shocks to the respondent's household net income and financial wealth with expected economic decisions. The outcomes are expected growth of yearly household spending from 2019 to 2020 in percent, trimmed at the 2nd and 98th percentiles (column 1); expected household spending growth in dollars, trimmed at the 2nd and 98th percentiles (columns 2-3); and dummies indicating whether the coronavirus crisis increases the respondent's expectations about outstanding household debt by the end of 2020 (column 4), expected desired working hours over the next years (column 5, only if in labor force) or expected retirement age (column 6, only if in labor force), coded as 0 or 100. Dollar changes in columns 2 and 3 are constructed from survey questions for retirement and other financial wealth and for income (assuming that the respondent expected a quarter of her 2019 income in the first quarter of 2020), and for spending from the survey question on percent changes and estimates of the level of spending of different groups in 2019 from the CEX. Columns 1, 2, 4, 5 and 6 show simple OLS estimates. Column 3 shows a 2SLS estimate, where the respondent's expected dollar change in household income from 2019 to 2020 is instrumented with the unexpected shock to household income in the first quarter. All specifications are based on the pure control group, which has not received any information and not answered any questions on past crashes. All specifications control for shocks to income and financial wealth, trimmed at the 2nd and 98th percentiles, gender, age, employment status, being the main earner, being financial decision-maker, party affiliation, log net household income, logs of retirement wealth, of other financial wealth, of real estate wealth, and of debt, borrowing constraints, stock market participation, risky portfolio share, investment experience, Census region, survey date, and the survey arm. Robust standard errors are reported in parentheses. * denotes significance at the 10 pct., $* *$ at the 5 pct., and $* * *$ at the 1 pct. level. 
Table A6: Determinants of expectations about the stock market and own wealth: Pure control only

\begin{tabular}{|c|c|c|c|c|c|c|c|c|}
\hline & $\begin{array}{c}\text { Stock } \\
\text { recovery } \\
\text { duration } \\
\end{array}$ & $\begin{array}{c}\text { Stock } \\
\text { return: } \\
\text { Mean } \\
\end{array}$ & $\begin{array}{l}\text { Stock } \\
\text { return: } \\
\text { SD } \\
\end{array}$ & $\begin{array}{l}\text { Stock } \\
\text { return } \\
<-30 \% \\
\end{array}$ & $\begin{array}{l}\text { Stock } \\
\text { return } \\
>30 \% \\
\end{array}$ & $\begin{array}{l}\text { Wealth } \\
\text { recovery } \\
\text { duration } \\
\end{array}$ & $\begin{array}{l}\text { Exp. wealth } \\
\text { never to } \\
\text { recover } \\
\end{array}$ & $\begin{array}{c}\text { Household } \\
\text { financial } \\
\text { prospects }\end{array}$ \\
\hline & (1) & $(2)$ & $(3)$ & $(4)$ & $(5)$ & (6) & $(7)$ & (8) \\
\hline$\Delta$ Fin. wealth $(\%)$ & $\begin{array}{l}-0.010^{*} \\
(0.006)\end{array}$ & $\begin{array}{c}0.020 \\
(0.058)\end{array}$ & $\begin{array}{l}-0.024 \\
(0.026)\end{array}$ & $\begin{array}{l}-0.032 \\
(0.065)\end{array}$ & $\begin{array}{l}-0.041 \\
(0.086)\end{array}$ & $\begin{array}{c}-0.022^{* * *} \\
(0.005)\end{array}$ & $\begin{array}{c}-0.229^{* *} \\
(0.113)\end{array}$ & $\begin{array}{c}0.010^{* * *} \\
(0.003)\end{array}$ \\
\hline$\Delta$ Net income $(\%)$ & $\begin{array}{l}-0.002 \\
(0.004)\end{array}$ & $\begin{array}{c}0.087^{* * *} \\
(0.033)\end{array}$ & $\begin{array}{l}-0.005 \\
(0.018)\end{array}$ & $\begin{array}{c}-0.111^{* *} \\
(0.043)\end{array}$ & $\begin{array}{c}0.087^{*} \\
(0.044)\end{array}$ & $\begin{array}{c}-0.006^{* *} \\
(0.003)\end{array}$ & $\begin{array}{l}-0.065 \\
(0.067)\end{array}$ & $\begin{array}{l}0.004^{* *} \\
(0.002)\end{array}$ \\
\hline Any loss fin. crisis & $\begin{array}{l}-0.138 \\
(0.156)\end{array}$ & $\begin{array}{l}-1.868 \\
(1.643)\end{array}$ & $\begin{array}{c}0.234 \\
(0.803)\end{array}$ & $\begin{array}{l}-1.043 \\
(1.798)\end{array}$ & $\begin{array}{l}-3.853 \\
(2.417)\end{array}$ & $\begin{array}{c}0.057 \\
(0.124)\end{array}$ & $\begin{array}{c}4.437 \\
(3.473)\end{array}$ & $\begin{array}{l}-0.113 \\
(0.087)\end{array}$ \\
\hline Big loss fin. crisis & $\begin{array}{c}0.168 \\
(0.215)\end{array}$ & $\begin{array}{c}0.693 \\
(2.222)\end{array}$ & $\begin{array}{l}-0.119 \\
(0.990)\end{array}$ & $\begin{array}{l}-0.744 \\
(2.414)\end{array}$ & $\begin{array}{c}3.531 \\
(3.386)\end{array}$ & $\begin{array}{l}-0.043 \\
(0.170)\end{array}$ & $\begin{array}{c}2.799 \\
(4.205)\end{array}$ & $\begin{array}{l}-0.098 \\
(0.111)\end{array}$ \\
\hline Any loss dot-com & $\begin{array}{c}0.100 \\
(0.171)\end{array}$ & $\begin{array}{l}-1.673 \\
(1.776)\end{array}$ & $\begin{array}{c}0.493 \\
(0.890)\end{array}$ & $\begin{array}{c}3.121 \\
(2.180)\end{array}$ & $\begin{array}{l}-0.379 \\
(2.549)\end{array}$ & $\begin{array}{c}0.229 \\
(0.161)\end{array}$ & $\begin{array}{l}-3.492 \\
(3.446)\end{array}$ & $\begin{array}{l}-0.046 \\
(0.097)\end{array}$ \\
\hline Big loss dot-com & $\begin{array}{c}-0.537^{* *} \\
(0.234)\end{array}$ & $\begin{array}{c}-0.211 \\
(3.496)\end{array}$ & $\begin{array}{l}-1.509 \\
(1.497)\end{array}$ & $\begin{array}{l}-1.645 \\
(3.785)\end{array}$ & $\begin{array}{c}2.219 \\
(5.506)\end{array}$ & $\begin{array}{l}-0.302 \\
(0.242)\end{array}$ & $\begin{array}{l}-3.943 \\
(6.226)\end{array}$ & $\begin{array}{l}0.340^{*} \\
(0.178)\end{array}$ \\
\hline Any loss Black Monday & $\begin{array}{c}0.139 \\
(0.215)\end{array}$ & $\begin{array}{l}-3.562 \\
(2.268)\end{array}$ & $\begin{array}{c}0.123 \\
(1.014)\end{array}$ & $\begin{array}{c}0.860 \\
(2.789)\end{array}$ & $\begin{array}{c}-6.867^{* *} \\
(3.124)\end{array}$ & $\begin{array}{c}0.138 \\
(0.191)\end{array}$ & $\begin{array}{l}-3.158 \\
(4.107)\end{array}$ & $\begin{array}{l}-0.010 \\
(0.117)\end{array}$ \\
\hline Big loss Black Monday & $\begin{array}{l}-0.118 \\
(0.254)\end{array}$ & $\begin{array}{c}0.864 \\
(3.843)\end{array}$ & $\begin{array}{l}-0.200 \\
(1.496)\end{array}$ & $\begin{array}{c}0.595 \\
(4.885)\end{array}$ & $\begin{array}{c}2.592 \\
(4.876)\end{array}$ & $\begin{array}{l}-0.206 \\
(0.237)\end{array}$ & $\begin{array}{c}21.798^{* *} \\
(8.856)\end{array}$ & $\begin{array}{l}-0.246 \\
(0.195)\end{array}$ \\
\hline Male & $\begin{array}{l}-0.170 \\
(0.169)\end{array}$ & $\begin{array}{l}-0.267 \\
(1.418)\end{array}$ & $\begin{array}{l}1.488^{* *} \\
(0.682)\end{array}$ & $\begin{array}{c}-0.556 \\
(1.716)\end{array}$ & $\begin{array}{c}0.515 \\
(2.033)\end{array}$ & $\begin{array}{l}-0.107 \\
(0.093)\end{array}$ & $\begin{array}{c}4.130 \\
(2.803)\end{array}$ & $\begin{array}{c}0.279^{* * *} \\
(0.076)\end{array}$ \\
\hline At least bachelor & $\begin{array}{l}-0.258 \\
(0.580)\end{array}$ & $\begin{array}{c}0.156 \\
(4.319)\end{array}$ & $\begin{array}{l}-1.612 \\
(1.874)\end{array}$ & $\begin{array}{l}-9.319 \\
(6.354)\end{array}$ & $\begin{array}{l}-4.785 \\
(5.214)\end{array}$ & $\begin{array}{l}-0.169 \\
(0.241)\end{array}$ & $\begin{array}{c}-0.711 \\
(7.900)\end{array}$ & $\begin{array}{c}0.194 \\
(0.182)\end{array}$ \\
\hline Republican & $\begin{array}{l}-0.194 \\
(0.151)\end{array}$ & $\begin{array}{c}6.885^{* * *} \\
(1.430)\end{array}$ & $\begin{array}{c}-0.271 \\
(0.665)\end{array}$ & $\begin{array}{c}-4.814^{* * *} \\
(1.733)\end{array}$ & $\begin{array}{c}7.546^{* * *} \\
(2.113)\end{array}$ & $\begin{array}{c}-0.249^{* *} \\
(0.108)\end{array}$ & $\begin{array}{l}-4.913^{*} \\
(2.780)\end{array}$ & $\begin{array}{c}0.325^{* * *} \\
(0.072)\end{array}$ \\
\hline Stock investor & $\begin{array}{c}-0.494^{*} \\
(0.279)\end{array}$ & $\begin{array}{l}-1.219 \\
(2.512)\end{array}$ & $\begin{array}{c}2.124 \\
(1.341)\end{array}$ & $\begin{array}{c}2.196 \\
(3.233)\end{array}$ & $\begin{array}{l}-1.204 \\
(3.619)\end{array}$ & $\begin{array}{c}0.613^{* * *} \\
(0.210)\end{array}$ & $\begin{array}{l}-0.679 \\
(5.395)\end{array}$ & $\begin{array}{c}0.165 \\
(0.144)\end{array}$ \\
\hline $\begin{array}{l}\text { Individual controls } \\
\text { Adj. R-squared } \\
\text { Observations }\end{array}$ & $\begin{array}{c}\text { Yes } \\
.045 \\
1,014\end{array}$ & $\begin{array}{c}\text { Yes } \\
.049 \\
1,014\end{array}$ & $\begin{array}{c}\text { Yes } \\
.049 \\
1,014\end{array}$ & $\begin{array}{c}\text { Yes } \\
.017 \\
1,014\end{array}$ & $\begin{array}{c}\text { Yes } \\
.055 \\
1,014\end{array}$ & $\begin{array}{l}\text { Yes } \\
.234 \\
941\end{array}$ & $\begin{array}{c}\text { Yes } \\
.075 \\
1,014\end{array}$ & $\begin{array}{c}\text { Yes } \\
.091 \\
1,014\end{array}$ \\
\hline
\end{tabular}

Notes: This table shows OLS estimates of the determinants of respondents' expectations about the stock market and their own wealth. The outcomes are the expected duration of the recovery from the current crash in years (column 1); mean and standard deviation as well as probabilities assigned to extreme return realizations based on the respondent's reported probability distribution over the one year-ahead stock market return (columns 2-5); the expected recovery duration of the respondent's household financial wealth (column 6); a dummy indicating whether the respondent thinks her household net wealth will never recover, coded as 0 or 100 (column 7); and a categorical measure of the respondent's subjective household financial prospects, z-scored using the mean and standard deviation in the sample (column 8). All specifications are based on the pure control group, which has not received any information and not answered any questions on past crashes. All specifications control for shocks to income and financial wealth, trimmed at the 2nd and 98th percentiles, dummies for having lost any wealth or substantial wealth during past stock market crashes, gender, age, employment status, being the main earner, being financial decision-maker, party affiliation, log net household income, logs of retirement wealth, of other financial wealth, of real estate wealth, and of debt, borrowing constraints, stock market participation, risky portfolio share, investment experience, Census region, and survey date. Robust standard errors are reported in parentheses. ${ }^{*}$ denotes significance at the 10 pct., ${ }^{* *}$ at the 5 pct., and ${ }^{* * *}$ at the 1 pct. level. 
Table A7: Correlational evidence on beliefs about past crashes

\begin{tabular}{|c|c|c|c|c|c|c|c|c|}
\hline & $\begin{array}{c}\begin{array}{c}\text { Stock } \\
\text { recovery } \\
\text { duration }\end{array} \\
\end{array}$ & $\begin{array}{c}\text { Agree: } \\
\text { Recovery } \\
\text { many yrs. } \\
\end{array}$ & $\begin{array}{c}\text { Agree: } \\
\text { Set back } \\
\text { many yrs. } \\
\end{array}$ & $\begin{array}{c}\text { Agree: } \\
\text { Recover } \\
2020 \\
\end{array}$ & $\begin{array}{c}\text { Stock } \\
\text { return: } \\
\text { Mean } \\
\end{array}$ & $\begin{array}{c}\text { Stock } \\
\text { return: } \\
\text { SD } \\
\end{array}$ & $\begin{array}{l}\text { Stock } \\
\text { return } \\
<-30 \% \\
\end{array}$ & $\begin{array}{l}\text { Stock } \\
\text { return } \\
>30 \% \\
\end{array}$ \\
\hline & $(1)$ & $(2)$ & (3) & $(4)$ & $(5)$ & (6) & $(7)$ & $(8)$ \\
\hline \multicolumn{9}{|l|}{ Panel A: Fin Crisis } \\
\hline $\begin{array}{l}\text { Prior recovery duration } \\
\text { Fin. Crisis } 2007\end{array}$ & $\begin{array}{c}0.245^{* * *} \\
(0.029)\end{array}$ & $\begin{array}{c}0.049^{* * *} \\
(0.009)\end{array}$ & $\begin{array}{c}0.048^{* * *} \\
(0.009)\end{array}$ & $\begin{array}{l}-0.017^{*} \\
(0.010)\end{array}$ & $\begin{array}{c}-0.153 \\
(0.169)\end{array}$ & $\begin{array}{c}0.101 \\
(0.094)\end{array}$ & $\begin{array}{c}0.153 \\
(0.231)\end{array}$ & $\begin{array}{l}-0.159 \\
(0.252)\end{array}$ \\
\hline Observations & 1,050 & 1,050 & 1,050 & 1,050 & 1,050 & 1,050 & 1,050 & 1,050 \\
\hline \multicolumn{9}{|l|}{ Panel B: Dot-com } \\
\hline $\begin{array}{l}\text { Prior recovery duration } \\
\text { Dot-com } 2000\end{array}$ & $\begin{array}{c}0.225^{* * *} \\
(0.025)\end{array}$ & $\begin{array}{c}0.032^{* * *} \\
(0.008)\end{array}$ & $\begin{array}{c}0.031^{* * *} \\
(0.008)\end{array}$ & $\begin{array}{c}-0.010 \\
(0.008)\end{array}$ & $\begin{array}{c}0.159 \\
(0.153)\end{array}$ & $\begin{array}{c}0.135^{*} \\
(0.076)\end{array}$ & $\begin{array}{c}0.010 \\
(0.196)\end{array}$ & $\begin{array}{c}0.355 \\
(0.228)\end{array}$ \\
\hline Observations & 1,063 & 1,063 & 1,063 & 1,063 & 1,063 & 1,063 & 1,063 & 1,063 \\
\hline \multicolumn{9}{|l|}{ Panel C: Black Monday } \\
\hline $\begin{array}{l}\text { Prior recovery duration } \\
\text { Black Monday } 1987\end{array}$ & $\begin{array}{c}0.313^{* * *} \\
(0.026)\end{array}$ & $\begin{array}{c}0.058^{* * *} \\
(0.007)\end{array}$ & $\begin{array}{c}0.051^{* * *} \\
(0.008)\end{array}$ & $\begin{array}{c}-0.034^{* * *} \\
(0.008)\end{array}$ & $\begin{array}{c}-0.409^{* * *} \\
(0.153)\end{array}$ & $\begin{array}{c}0.229^{* * *} \\
(0.073)\end{array}$ & $\begin{array}{c}0.541^{* * *} \\
(0.201)\end{array}$ & $\begin{array}{l}-0.217 \\
(0.228)\end{array}$ \\
\hline Observations & 1,058 & 1,058 & 1,058 & 1,058 & 1,058 & 1,058 & 1,058 & 1,058 \\
\hline Individual controls & Yes & Yes & Yes & Yes & Yes & Yes & Yes & Yes \\
\hline
\end{tabular}

Notes: This table shows OLS estimates of the effect of prior beliefs about the duration of a past stock market crash on the respondent's expectations about the stock market. The outcomes are the expected duration of the recovery from the current crash in years (column 1); agreement on 7-point scales to statements describing the severity of the current stock market crash, z-scored using the mean and the standard deviation in the sample (columns 2-4); mean and standard deviation as well as probabilities assigned to extreme return realizations based on the respondent's reported probability distribution over the one year-ahead stock market return (columns 5-8). Panel A is based on the control arm including questions on the Financial Crisis 2007. Panel B is based on the control arm including questions on the burst of the Dot-com bubble 2000. Panel C is based on the control arm including questions on the Black Monday 1987. All specifications control for gender, age, employment status, being the main earner, being financial decision-maker, party affiliation, log net household income, logs of retirement wealth, of other financial wealth, of real estate wealth, and of debt, borrowing constraints, stock market participation, the equity share in total financial assets, investment experience, Census region and survey date. Robust standard errors are reported in parentheses. ${ }^{*}$ denotes significance at the 10 pct., ${ }^{* *}$ at the 5 pct., and *** at the 1 pct. level. 
Table A8: Effects of information on own outlook and plans: Experimental reduced form

\begin{tabular}{|c|c|c|c|c|c|c|c|c|}
\hline & $\begin{array}{c}\text { Wealth } \\
\text { recovery } \\
\text { duration } \\
\end{array}$ & $\begin{array}{c}\begin{array}{c}\text { Household } \\
\text { financial } \\
\text { prospects }\end{array} \\
\end{array}$ & $\begin{array}{c}\text { Plan incr. } \\
\text { stock } \\
\text { share } \\
\end{array}$ & $\begin{array}{c}\text { Plan decr. } \\
\text { stock } \\
\text { share } \\
\end{array}$ & $\begin{array}{c}\text { Exp. } \\
\text { spend. } \\
\text { growth } \\
\end{array}$ & $\begin{array}{l}\text { Incr. } \\
\text { exp. } \\
\text { debt }\end{array}$ & $\begin{array}{c}\text { Incr. exp. } \\
\text { desired } \\
\text { hours } \\
\end{array}$ & $\begin{array}{l}\text { Incr. exp. } \\
\text { retirement } \\
\text { age }\end{array}$ \\
\hline & (1) & $(2)$ & (3) & $(4)$ & $(5)$ & (6) & $(7)$ & $(8)$ \\
\hline \multicolumn{9}{|l|}{ Panel A: All } \\
\hline Info Fin. Crisis 2007 & $\begin{array}{c}0.484^{* * *} \\
(0.078)\end{array}$ & $\begin{array}{c}-0.100^{* *} \\
(0.043)\end{array}$ & $\begin{array}{c}0.952 \\
(1.931)\end{array}$ & $\begin{array}{l}3.054^{*} \\
(1.818)\end{array}$ & $\begin{array}{l}-0.951 \\
(0.914)\end{array}$ & $\begin{array}{c}0.335 \\
(1.924)\end{array}$ & $\begin{array}{l}6.429^{* *} \\
(2.632)\end{array}$ & $\begin{array}{l}5.186^{*} \\
(2.662)\end{array}$ \\
\hline \multicolumn{9}{|l|}{ Panel B: Underestimators } \\
\hline Info Fin. Crisis 2007 & $\begin{array}{c}0.522^{* * *} \\
(0.086)\end{array}$ & $\begin{array}{l}-0.099^{*} \\
(0.052)\end{array}$ & $\begin{array}{c}2.827 \\
(2.333)\end{array}$ & $\begin{array}{c}3.215 \\
(2.211)\end{array}$ & $\begin{array}{l}-1.478 \\
(1.106)\end{array}$ & $\begin{array}{c}2.978 \\
(2.381)\end{array}$ & $\begin{array}{l}7.401^{* *} \\
(3.210)\end{array}$ & $\begin{array}{l}8.229^{* *} \\
(3.235)\end{array}$ \\
\hline \multicolumn{9}{|l|}{ Panel C: Under. \& Stocks $>0$} \\
\hline Info Fin. Crisis 2007 & $\begin{array}{c}0.761^{* * *} \\
(0.130)\end{array}$ & $\begin{array}{c}-0.136^{* *} \\
(0.066)\end{array}$ & $\begin{array}{c}2.827 \\
(2.333)\end{array}$ & $\begin{array}{c}3.215 \\
(2.211)\end{array}$ & $\begin{array}{l}-1.281 \\
(1.328)\end{array}$ & $\begin{array}{c}3.101 \\
(3.002)\end{array}$ & $\begin{array}{l}9.099^{* *} \\
(3.773)\end{array}$ & $\begin{array}{l}8.995^{* *} \\
(3.917)\end{array}$ \\
\hline \multicolumn{9}{|l|}{ Panel D: All } \\
\hline Info Dot-com 2000 & $\begin{array}{c}0.573^{* * *} \\
(0.087)\end{array}$ & $\begin{array}{c}0.009 \\
(0.043)\end{array}$ & $\begin{array}{c}0.285 \\
(2.015)\end{array}$ & $\begin{array}{l}-2.085 \\
(1.843)\end{array}$ & $\begin{array}{l}-1.255 \\
(0.928)\end{array}$ & $\begin{array}{c}-1.477 \\
(1.909)\end{array}$ & $\begin{array}{l}-4.891^{*} \\
(2.623)\end{array}$ & $\begin{array}{l}-3.710 \\
(2.664)\end{array}$ \\
\hline \multicolumn{9}{|l|}{ Panel E: Underestimators } \\
\hline Info Dot-com 2000 & $\begin{array}{c}0.683^{* * *} \\
(0.109)\end{array}$ & $\begin{array}{c}0.022 \\
(0.054)\end{array}$ & $\begin{array}{c}1.149 \\
(2.601)\end{array}$ & $\begin{array}{l}-2.967 \\
(2.279)\end{array}$ & $\begin{array}{l}-0.533 \\
(1.141)\end{array}$ & $\begin{array}{l}-1.019 \\
(2.334)\end{array}$ & $\begin{array}{l}-4.145 \\
(3.251)\end{array}$ & $\begin{array}{l}-3.243 \\
(3.321)\end{array}$ \\
\hline \multicolumn{9}{|l|}{ Panel F: Under. \& Stocks $>0$} \\
\hline Info Dot-com 2000 & $\begin{array}{c}1.017^{* * *} \\
(0.164)\end{array}$ & $\begin{array}{c}0.051 \\
(0.069)\end{array}$ & $\begin{array}{c}1.149 \\
(2.601)\end{array}$ & $\begin{array}{l}-2.967 \\
(2.279)\end{array}$ & $\begin{array}{c}0.779 \\
(1.374)\end{array}$ & $\begin{array}{c}0.167 \\
(2.898)\end{array}$ & $\begin{array}{l}-1.328 \\
(3.822)\end{array}$ & $\begin{array}{l}-3.998 \\
(3.974)\end{array}$ \\
\hline \multicolumn{9}{|l|}{ Panel G: All } \\
\hline Info Black Monday 1987 & $\begin{array}{c}-0.157^{* *} \\
(0.074)\end{array}$ & $\begin{array}{c}0.048 \\
(0.042)\end{array}$ & $\begin{array}{l}3.293^{*} \\
(1.984)\end{array}$ & $\begin{array}{l}-2.228 \\
(1.710)\end{array}$ & $\begin{array}{l}-1.027 \\
(0.924)\end{array}$ & $\begin{array}{c}-5.598^{* * *} \\
(1.877)\end{array}$ & $\begin{array}{l}-0.566 \\
(2.612)\end{array}$ & $\begin{array}{l}-0.806 \\
(2.611)\end{array}$ \\
\hline \multicolumn{9}{|l|}{ Panel H: Overestimators } \\
\hline Info Black Monday 1987 & $\begin{array}{c}-0.242^{* * *} \\
(0.088)\end{array}$ & $\begin{array}{c}0.088^{*} \\
(0.047)\end{array}$ & $\begin{array}{l}4.647^{* *} \\
(2.253)\end{array}$ & $\begin{array}{c}-4.079^{* *} \\
(1.981)\end{array}$ & $\begin{array}{l}-0.066 \\
(1.070)\end{array}$ & $\begin{array}{c}-6.705^{* * *} \\
(2.141)\end{array}$ & $\begin{array}{l}-1.607 \\
(2.953)\end{array}$ & $\begin{array}{l}-4.698 \\
(2.962)\end{array}$ \\
\hline $\begin{array}{l}\text { Panel I: Over. \& Stocks > } \\
\text { Info Black Monday } 1987\end{array}$ & $\begin{array}{c}-0.385^{* * *} \\
(0.146)\end{array}$ & $\begin{array}{c}0.097 \\
(0.062)\end{array}$ & $\begin{array}{l}4.647^{* *} \\
(2.253)\end{array}$ & $\begin{array}{l}-4.079^{* *} \\
(1.981)\end{array}$ & $\begin{array}{c}1.296 \\
(1.361)\end{array}$ & $\begin{array}{l}-5.026^{*} \\
(2.709)\end{array}$ & $\begin{array}{l}-1.170 \\
(3.558)\end{array}$ & $\begin{array}{l}-3.673 \\
(3.609)\end{array}$ \\
\hline Individual controls & Yes & Yes & Yes & Yes & Yes & Yes & Yes & Yes \\
\hline
\end{tabular}

Notes: This table shows OLS estimates of the effect of being shown information on the duration of a past stock market crash on the respondent's expectations about her own financial situation and behavior. The outcomes are the expected recovery duration of the respondent's household financial wealth (column 1); a categorical measure of the respondent's subjective household financial prospects, z-scored using the mean and standard deviation in the sample (column 2); dummies indicating plans to increase or decrease the risky share in overall financial assets in the weeks after the survey (columns 3-4, only for stockholders); expected growth of yearly household spending from 2019 to 2020 in percent, trimmed at the 2nd and 98th percentiles (column 5); dummies indicating whether the coronavirus crisis increases the respondent's expectations about outstanding household debt by the end of 2020 (column 6), expected desired working hours over the next years (column 7, only if in labor force) or expected retirement age (column 8 , only if in labor force). All dummy outcomes are coded as 0 or 100. Panels A-C are based on the treatment and control arms including information or questions on the Financial Crisis 2007. Panels D-F are based on the treatment and control arms including information or questions on the burst of the Dot-com bubble 2000. Panels G-I are based on the treatment and control arms including information or questions on the Black Monday 1987. Panels A, D and G are based on the full sample in the corresponding arms. Panels B, E and H are based only on under-estimators (for Financial Crisis and Dot-com bubble) or overestimators (for Black Monday) of the length of the recovery from the crash. Panels C, F and I are based only on under-estimators or over-estimators who participated in the stock market before the current crisis. All specifications control for the respondent's prior belief about the recovery duration following the corresponding crash as well as for gender, age, employment status, being the main earner, being financial decision-maker, party affiliation, log net household income, logs of retirement wealth, of other financial wealth, of real estate wealth, and of debt, borrowing constraints, stock market participation, the equity share in total financial assets, investment experience, Census region and survey date. The specifications on planned stock trading in columns 3 and 4 also control for realized trading since the onset of the crisis. Robust standard errors are reported in parentheses. ${ }^{*}$ denotes significance at the 10 pct., ${ }^{* *}$ at the 5 pct., and ${ }^{* * *}$ at the 1 pct. level. 
Table A9: Effects of expected stock market recovery on own outlook and plans: Heterogeneity

\begin{tabular}{|c|c|c|c|c|c|c|c|c|}
\hline & $\begin{array}{l}\text { Wealth } \\
\text { recovery } \\
\text { duration } \\
\end{array}$ & $\begin{array}{c}\text { Household } \\
\text { financial } \\
\text { prospects } \\
\end{array}$ & $\begin{array}{c}\text { Plan incr. } \\
\text { stock } \\
\text { share } \\
\end{array}$ & $\begin{array}{c}\text { Plan decr. } \\
\text { stock } \\
\text { share } \\
\end{array}$ & $\begin{array}{l}\text { Exp. } \\
\text { spend. } \\
\text { growth } \\
\end{array}$ & $\begin{array}{l}\text { Incr. } \\
\text { exp. } \\
\text { debt }\end{array}$ & $\begin{array}{c}\text { Incr. exp. } \\
\text { desired } \\
\text { hours } \\
\end{array}$ & $\begin{array}{l}\text { Incr. exp. } \\
\text { retirement } \\
\text { age } \\
\end{array}$ \\
\hline & $(1)$ & $\begin{array}{l}(2) \\
\end{array}$ & $(3)$ & $(4)$ & $(5)$ & $(6)$ & $(7)$ & $(8)$ \\
\hline \multicolumn{9}{|l|}{ Panel A: Age $\leq$ median } \\
\hline Expected stock recovery duration (years) & $\begin{array}{c}0.244^{* * *} \\
(0.078)\end{array}$ & $\begin{array}{c}-0.047^{* * *} \\
(0.012)\end{array}$ & $\begin{array}{l}-0.809^{*} \\
(0.420)\end{array}$ & $\begin{array}{c}0.396 \\
(0.415)\end{array}$ & $\begin{array}{l}-0.317 \\
(0.272)\end{array}$ & $\begin{array}{l}-0.145 \\
(0.490)\end{array}$ & $\begin{array}{c}2.085^{* * *} \\
(0.525)\end{array}$ & $\begin{array}{c}1.922^{* * *} \\
(0.535)\end{array}$ \\
\hline \multicolumn{9}{|l|}{ Panel B: Age > median } \\
\hline Expected stock recovery duration (years) & $\begin{array}{c}0.995^{* * *} \\
(0.082)\end{array}$ & $\begin{array}{c}-0.128^{* * *} \\
(0.011)\end{array}$ & $\begin{array}{l}-0.190 \\
(0.356)\end{array}$ & $\begin{array}{l}0.750^{* *} \\
(0.375)\end{array}$ & $\begin{array}{c}-0.730^{* * *} \\
(0.222)\end{array}$ & $\begin{array}{l}1.236^{* *} \\
(0.496)\end{array}$ & $\begin{array}{l}2.179^{* *} \\
(0.854)\end{array}$ & $\begin{array}{l}2.136^{* *} \\
(0.909)\end{array}$ \\
\hline $\mathrm{p}$-value $(\mathrm{A}=\mathrm{B})$ & 0.00 & 0.00 & 0.26 & 0.53 & 0.24 & 0.05 & 0.93 & 0.84 \\
\hline \multicolumn{9}{|l|}{ Panel C: Net income $\leq$ median } \\
\hline Expected stock recovery duration (years) & $\begin{array}{c}0.529^{* * *} \\
(0.099)\end{array}$ & $\begin{array}{c}-0.085^{* * *} \\
(0.012)\end{array}$ & $\begin{array}{l}-0.739^{*} \\
(0.402)\end{array}$ & $\begin{array}{c}0.506 \\
(0.440)\end{array}$ & $\begin{array}{l}-0.348 \\
(0.292)\end{array}$ & $\begin{array}{l}1.234^{* *} \\
(0.534)\end{array}$ & $\begin{array}{c}2.063^{* * *} \\
(0.744)\end{array}$ & $\begin{array}{l}1.407^{*} \\
(0.790)\end{array}$ \\
\hline $\begin{array}{l}\text { Panel D: Net income }>\text { median } \\
\text { Expected stock recovery duration (years) }\end{array}$ & $\begin{array}{c}0.698^{* * *} \\
(0.070)\end{array}$ & $\begin{array}{c}-0.090^{* * *} \\
(0.012)\end{array}$ & $\begin{array}{l}-0.554 \\
(0.398)\end{array}$ & $\begin{array}{c}0.580 \\
(0.356)\end{array}$ & $\begin{array}{c}-0.762^{* * *} \\
(0.226)\end{array}$ & $\begin{array}{l}0.158 \\
(0.431)\end{array}$ & $\begin{array}{c}2.184^{* * *} \\
(0.556)\end{array}$ & $\begin{array}{c}2.853^{* * *} \\
(0.570)\end{array}$ \\
\hline $\mathrm{p}$-value $(\mathrm{C}=\mathrm{D})$ & 0.16 & 0.72 & 0.74 & 0.90 & 0.26 & 0.12 & 0.90 & 0.14 \\
\hline \multicolumn{9}{|l|}{ Panel E: Net wealth $\leq$ median } \\
\hline Expected stock recovery duration (years) & $\begin{array}{c}0.739^{* * *} \\
(0.066)\end{array}$ & $\begin{array}{c}-0.102^{* * *} \\
(0.010)\end{array}$ & $\begin{array}{l}-0.540 \\
(0.336)\end{array}$ & $\begin{array}{l}0.669^{* *} \\
(0.312)\end{array}$ & $\begin{array}{c}-0.649^{* * *} \\
(0.204)\end{array}$ & $\begin{array}{l}0.695^{*} \\
(0.385)\end{array}$ & $\begin{array}{c}2.421^{* * *} \\
(0.553)\end{array}$ & $\begin{array}{c}2.661^{* * *} \\
(0.573)\end{array}$ \\
\hline $\begin{array}{l}\text { Panel F: Net wealth }>\text { median } \\
\text { Expected stock recovery duration (years) }\end{array}$ & $\begin{array}{c}0.348^{* * *} \\
(0.116)\end{array}$ & $\begin{array}{c}-0.057^{* * *} \\
(0.015)\end{array}$ & $\begin{array}{l}-0.709 \\
(0.506)\end{array}$ & $\begin{array}{c}0.168 \\
(0.552)\end{array}$ & $\begin{array}{l}-0.332 \\
(0.343)\end{array}$ & $\begin{array}{l}0.253 \\
(0.657)\end{array}$ & $\begin{array}{l}1.289 \\
(0.791)\end{array}$ & $\begin{array}{c}1.107 \\
(0.788)\end{array}$ \\
\hline $\mathrm{p}$-value $(\mathrm{E}=\mathrm{F})$ & 0.00 & 0.02 & 0.78 & 0.43 & 0.43 & 0.56 & 0.24 & 0.11 \\
\hline \multicolumn{9}{|l|}{ Panel G: Female } \\
\hline Expected stock recovery duration (years) & $\begin{array}{c}0.488^{* * *} \\
(0.082)\end{array}$ & $\begin{array}{c}-0.078^{* * *} \\
(0.011)\end{array}$ & $\begin{array}{c}-0.750^{* *} \\
(0.355)\end{array}$ & $\begin{array}{c}0.570 \\
(0.380)\end{array}$ & $\begin{array}{c}-0.586^{* *} \\
(0.230)\end{array}$ & $\begin{array}{c}0.339 \\
(0.477)\end{array}$ & $\begin{array}{c}2.755^{* * *} \\
(0.689)\end{array}$ & $\begin{array}{c}1.871^{* * *} \\
(0.682)\end{array}$ \\
\hline \multicolumn{9}{|l|}{ Panel H: Male } \\
\hline Expected stock recovery duration (years) & $\begin{array}{c}0.710^{* * *} \\
(0.084)\end{array}$ & $\begin{array}{c}-0.102^{* * *} \\
(0.013)\end{array}$ & $\begin{array}{l}-0.409 \\
(0.456)\end{array}$ & $\begin{array}{c}0.516 \\
(0.420)\end{array}$ & $\begin{array}{c}-0.575^{* *} \\
(0.277)\end{array}$ & $\begin{array}{c}0.669 \\
(0.482)\end{array}$ & $\begin{array}{l}1.508^{* *} \\
(0.595)\end{array}$ & $\begin{array}{c}2.211^{* * *} \\
(0.631)\end{array}$ \\
\hline $\mathrm{p}$-value $(\mathrm{G}=\mathrm{H})$ & 0.06 & 0.16 & 0.55 & 0.92 & 0.98 & 0.63 & 0.17 & 0.71 \\
\hline \multicolumn{9}{|l|}{ Panel I: Below Bachelor } \\
\hline Expected stock recovery duration (years) & $\begin{array}{c}0.507^{* * *} \\
(0.085)\end{array}$ & $\begin{array}{c}-0.083^{* * *} \\
(0.011)\end{array}$ & $\begin{array}{l}-0.596 \\
(0.364)\end{array}$ & $\begin{array}{l}0.673^{*} \\
(0.364)\end{array}$ & $\begin{array}{l}-0.359 \\
(0.241)\end{array}$ & $\begin{array}{l}0.986^{* *} \\
(0.461)\end{array}$ & $\begin{array}{c}2.030^{* * *} \\
(0.589)\end{array}$ & $\begin{array}{c}2.093^{* * *} \\
(0.620)\end{array}$ \\
\hline $\begin{array}{l}\text { Panel J: At least Bachelor } \\
\text { Expected stock recovery duration (years) }\end{array}$ & $\begin{array}{c}0.714^{* * *} \\
(0.078)\end{array}$ & $\begin{array}{c}-0.092^{* * *} \\
(0.013)\end{array}$ & $\begin{array}{l}-0.694 \\
(0.436)\end{array}$ & $\begin{array}{c}0.497 \\
(0.409)\end{array}$ & $\begin{array}{c}-0.730^{* * *} \\
(0.256)\end{array}$ & $\begin{array}{l}-0.034 \\
(0.496)\end{array}$ & $\begin{array}{c}2.277^{* * *} \\
(0.683)\end{array}$ & $\begin{array}{c}2.082^{* * *} \\
(0.679)\end{array}$ \\
\hline $\mathrm{p}$-value $(\mathrm{I}=\mathrm{J})$ & 0.07 & 0.61 & 0.86 & 0.75 & 0.29 & 0.13 & 0.78 & 0.99 \\
\hline Individual controls & Yes & Yes & Yes & Yes & Yes & Yes & Yes & Yes \\
\hline
\end{tabular}

Notes: This table shows OLS estimates of the effects of respondents' expected stock market recovery duration on the respondent's expectations about her own situation and behavior for different subgroups. The outcomes are the expected recovery duration of the respondent's household net wealth (column 1); a categorical measure of the respondent's subjective household financial prospects, z-scored using the mean and standard deviation in the sample (column 2); dummies indicating plans to increase or decrease the risky share in overall financial assets in the weeks after the survey (columns 3-4, only for stockholders); expected growth of yearly household spending from 2019 to 2020 in percent, trimmed at the 2nd and 98th percentiles (column 5); dummies indicating whether the coronavirus crisis increases the respondent's expectations about outstanding household debt by the end of 2020 (column 6), expected desired working hours over the next years (column 7 , only if in labor force) or expected retirement age (column 8 , only if in labor force). All dummy outcomes are coded as 0 or 100. All estimations are based on the four control arms, which have not received any information, and are restricted to those who participated in the stock market before the current crisis. All specifications control for gender, age, employment status, being the main earner, being financial decision-maker, party affiliation, log net household income, logs of retirement wealth, of other financial wealth, of real estate wealth, and of debt, borrowing constraints, stock market participation, the equity share in total financial assets, investment experience, Census region and survey date. The specifications on planned stock trading in columns 3 and 4 also control for realized trading since the onset of the crisis. Robust standard errors are reported in parentheses. * denotes significance at the 10 pct., ${ }^{* *}$ at the 5 pct., and ${ }^{* * *}$ at the 1 pct. level. 
Table A10: Perceived purpose of the survey

\begin{tabular}{|c|c|c|c|c|c|}
\hline & All & $\begin{array}{l}\text { All, excl. } \\
\text { pure ctrl }\end{array}$ & $\begin{array}{c}\text { Info treat., } \\
\text { all }\end{array}$ & $\begin{array}{c}\text { Ctrl. all, ex } \\
\text { pure ctrl. }\end{array}$ & $\begin{array}{c}\text { Difference } \\
(4)-(3)\end{array}$ \\
\hline & (1) & (2) & (3) & (4) & (5) \\
\hline Impact COVID-19 on HH finances & 47.25 & 46.29 & 44.62 & 47.97 & $\begin{array}{c}3.35^{* *} \\
{[2.68]}\end{array}$ \\
\hline Expectations & 10.23 & 10.54 & 11.39 & 9.68 & $\begin{array}{l}-1.71^{*} \\
{[-2.22]}\end{array}$ \\
\hline Knowledge test & 2.73 & 2.88 & 3.36 & 2.40 & $\begin{array}{l}-0.96^{*} \\
{[-2.29]}\end{array}$ \\
\hline Comparison of fin. crises & 2.32 & 2.56 & 3.01 & 2.11 & $\begin{array}{l}-0.90^{*} \\
{[-2.27]}\end{array}$ \\
\hline Experiment & 0.07 & 0.08 & 0.09 & 0.06 & $\begin{array}{l}-0.03 \\
{[-0.44]}\end{array}$ \\
\hline Do not know & 3.32 & 3.40 & 3.83 & 2.96 & $\begin{array}{c}-0.86 \\
{[-1.90]}\end{array}$ \\
\hline Other & 34.08 & 34.26 & 33.70 & 34.82 & $\begin{array}{c}1.12 \\
{[0.94]}\end{array}$ \\
\hline Observations & 7,447 & 6,358 & 3,187 & 3,171 & \\
\hline
\end{tabular}

Notes: This table shows the relative frequency (in \%) of answers to the question "What do you think was the purpose of the survey?" Answers were given as free text entries. We manually categorize the answers into 8 categories based on meaningful keywords, (1) impact of the corona crisis on household finances, (2) household economic expectations, (3) knowledge test/education, (4) comparison of different financial crises, (6) some form of experiment, (7) do not know, and (8) other. Column 1 is based on the entire sample. Column 2 excludes respondents in the pure control group, who have not received any questions or information on previous crashes. Column 3 is based on respondents in the three information treatment arms FinCrisisInfo, DotComInfo and BlackMondayInfo. Column 4 is based on respondents in the three control treatment arms FinCrisisCtrl, DotComCtrl and BlackMondayCtrl, excluding the pure control group. Column 5 shows the differences across percentages in the treatment and control arms, excluding the pure control group. ${ }^{*}$ denotes significance at the 10 pct., ${ }^{* *}$ at the 5 pct., and ${ }^{* * *}$ at the 1 pct. level. 


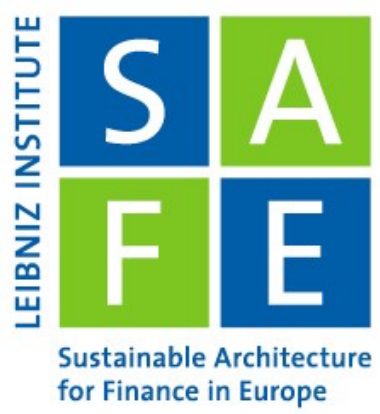

\section{Recent Issues}

No. 278 Sandra Eckert

No. 277 Dominique M. Lammer, Tobin Hanspal, Andreas Hackethal

No. 276 Massimiliano Caporin, Loriana Pelizzon, Alberto Plazzi

No. 275 Loriana Pelizzon, Max Riedel, Zorka Simon, Marti Subrahmanyam

No. 274 Christopher Busch, Alexander Ludwig

No. 273 Di Bu, Tobin Hanspal, Yin Liao, Yong Liu

No. 272 Christine Laudenbach, Benjamin Loos, Jenny Pirschel, Johannes Wohlfart

No. 271 Pietro Dindo, Andrea Modena, Loriana Pelizzon

No. 270 Mario Bellia, Kim Christensen, Aleksey Kolokolov, Loriana Pelizzon, Roberto Renó

No. 269 Ester Faia, Maximilian Mayer, Vincenzo Pezone

No. 268 Lorenzo Maria Levati, Marie Lalanne

No. 267 Wataru Kureishi, Hannah PaulePaludkiewicz, Hitoshi Tsujiyama, Midori Wakabayashi

No. 266 Benjamin Bluhm, Jannic Cutura

No. 265 Christian Schlag, Julian Thimme, Rüdiger Weber
EU Agencies in Banking and Energy Between Institutional and Policy Centralisation

Who Are the Bitcoin Investors? Evidence from Indirect Cryptocurrency Investments

Does Monetary Policy Impact International Market Co-Movements?

Collateral Eligibility of Corporate Debt in the Eurosystem

Higher-Order Income Risk Over the Business Cycle

Financial Literacy and Self-Control in FinTech: Evidence from a Field Experiment on Online Consumer Borrowing

The Trading Response of Individual Investors to Local Bankruptcies

Risk Pooling, Leverage, and the Business Cycle

High-Frequency Trading During Flash

Crashes: Walk of Fame or Hall of Shame?

The Value of Firm Networks: A Natural Experiment on Board Connections

The Impact of Job Referrals on Employment Outcomes in Top Corporate Positions

Time Preferences over the Life Cycle

Econometrics at Scale: Spark Up Big Data in Economics

Implied Volatility Duration: A Measure for the Timing of Uncertainty Resolution 